EbER de MeIra FERREIRA

Poder Judiciário, Ativismo Judicial e Democracia

Dissertação de Mestrado

Orientador: Prof. Dr. Rubens Beçak

Faculdade de Direito da Universidade de São Paulo - USP SÃo PaUlo

2014 
Poder JUdiciário, Ativismo Judicial e Democracia

Dissertação de mestrado apresentada como requisito parcial para a conclusão do curso de Mestrado em Direito, Área Direito do Estado, Subárea Direito Constitucional, sob orientação do Prof. Dr. Rubens Beçak.

Faculdade de Direito da Universidade de São Paulo - USP SÃo PAULO 


\title{
Poder Judiciário, Ativismo Judicial e Democracia
}

\author{
Dissertação de mestrado apresentada como \\ requisito parcial para a conclusão do curso de \\ Mestrado em Direito, Área Direito do Estado, \\ Subárea Direito Constitucional, sob orientação \\ do Prof. Dr. Rubens Beçak.
}

Aprovado em de de 2014

\author{
BANCA EXAMINADORA
}

Prof. Dr. Rubens Beçak

São Paulo 
Aos meus pais, João e Marisa. 


\section{Agradecimentos}

Aos meus pais João e Marisa, com os quais compartilho o fruto de aproximados três anos de esforço e dedicação, pela realização de um sonho possível graças à dedicação em minha educação e na construção de meu caráter, meu eterno agradecimento pelo apoio e amor incondicionais, por seus exemplos de perseverança e retidão.

A Priscilla, pela confiança em mim depositada, pelo apoio e conforto nos momentos difíceis, por sua compreensão ao longo da realização deste trabalho, agradeço por poder desfrutar de sua alegria expressa a cada passo por mim conquistado, e acima de tudo, por seu amor.

A minha irmã, Adriana, pelo carinho, apoio e auxílio em todos os momentos ao longo da realização deste trabalho, por seu amor fraternal e cumplicidade.

A Faculdade de Direito do Largo de São Francisco, com orgulho às eternas Arcadas que me inspiram na busca pelo conhecimento e fortalecem minha crença no Estado Democrático de Direito, aos docentes do Departamento de Direito do Estado, pelo amadurecimento de minha formação acadêmica e de meu espírito crítico, em especial ao professor Rubens Beçak por sua orientação atenta e prodigiosa.

Aos funcionários da Faculdade de Direito do Largo de São Francisco, pela cordialidade e auxílio constantes, em especial aos servidores da Biblioteca e Secretaria de Pós Graduação.

In memoriam de Janira Soares de Arruda Meira, por sua preocupação com "meu estudo", pelo exemplo inabalável de fé, caráter e sabedoria.

Aos demais familiares e amigos.

Sobretudo a Deus, pela sabedoria e discernimento. 


\section{Resumo}

O princípio da separação de poderes sofreu alterações fundamentais ao longo dos mais de três séculos desde sua consagração. Dentre as alterações na balança dos poderes, destacase a evolução do Poder Judiciário, com o alargamento de suas funções e aumento de sua importância se comparado em face da concepção clássica. No contexto brasileiro pós Constituição de 1988, dois fatores têm se mostrado fundamentais ao avanço do Poder Judiciário a uma posição de destaque no cenário político e constitucional: o desenvolvimento sistema de controle de constitucionalidade aliado às características das normas do texto constitucional, aliados a outros fatores, permitindo o seu avanço ao campo do chamado ativismo judicial. Dentro desta abordagem, o presente estudo busca apontar as implicações desta nova forma de atuação do Poder Judiciário denominada de ativismo judicial em face da democracia, analisando os principais pontos de tensão e críticas surgidas de seu confronto.

Palavras-chave: Separação de poderes. Poder judiciário. Controle de constitucionalidade. Ativismo judicial. Democracia. 


\begin{abstract}
The principle of separation of powers has undergone fundamental changes over the last three centuries since its establishment. Among the changes in the balance of powers, there is the evolution of the judiciary, with the enlargement of its functions and increase its importance compared in view of the classical conception of the separation of powers principle. In the Brazilian context after the 1988 Constitution, two factors have been shown to be fundamental to the advancement of the Judiciary to a prominent position in political and constitutional landscape, the development of the mechanisms of judicial review combined with the features of constitucional norms, also combined with other factors, allowing its advancement to the field of so-called judicial activism. Within this approach, this study seeks to identify the implications of this new form of action of the Judiciary called judicial activism in the face of democracy, analyzing the main points of tension and conflict that arises from them.
\end{abstract}

Key-words: Separation of powers. Judiciary. Judicial review. Judicial activism. Democracy. 


\section{SUMÁRIO}

INTRODUÇÃ

1. BREVES APONTAMENTOS SOBRE A TEORIA DA SEPARAÇÃO DE PODERES................ 17

2. Poder Judiciário e a República Brasileira ................................................... 45

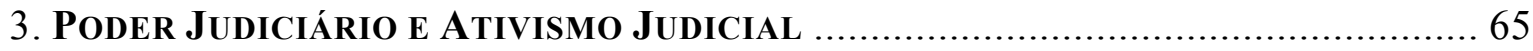

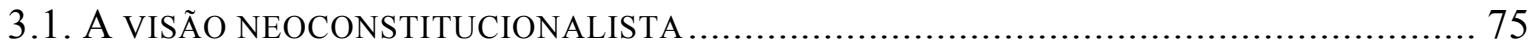

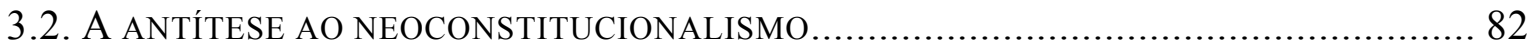

4. O Poder Judiciário Como INTÉrPRETE de VALORES dA SOCIEDAdE ............... 88

5. A PROBLemÁtica ENTRE ATIVISMO JUdicial E deMoCRACIA........................... 115

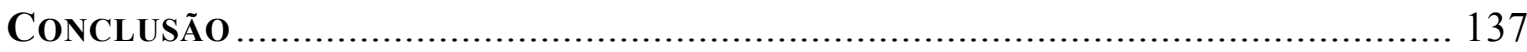

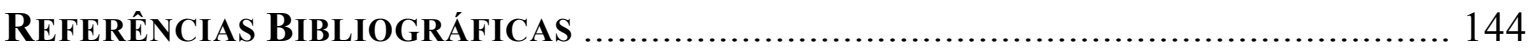




\section{INTRODUÇÃO}

A tarefa confiada a este trabalho, o debate sobre uma possível tensão entre Poder Judiciário, ativismo judicial e democracia, grandes temas que servem de título à presente dissertação, deve inicialmente, adentrar na análise de questões fundamentais que orbitam em torno destes tópicos, e principalmente, outorgam a base necessária ao seu enfrentamento.

O olhar sobre as revoluções liberais dos séculos XVII e XVIII, em especial a Revolução Francesa de 1.789, nos permite afirmar que princípios e concepções formuladas àquela época ditaram os rumos do Estado nos moldes concebidos no mundo ocidental.

Embora as nuances se alterem de acordo com as formas de governo adotadas, não restam dúvidas sobre a existência de um núcleo essencial legado pelo chamado constitucionalismo moderno, sob a influência fundamental da Revolução Francesa do último quartel do século XVIII, sem olvidar da devida menção à fundamental contribuição do pensamento inglês e norte-americano.

A base deste constitucionalismo moderno reside na ideia segundo a qual, este movimento herdado do período de revoluções "reclama não só a adoção em todos os Estados do orbe de constituições escritas, documentais, mas que elas tenham como conotação o desiderato de impedir o arbítrio."1

Nas palavras de N. Matteucci, citado na obra de referência de José Joaquim Gomes Canotilho, "o constitucionalismo moderno representará uma técnica específica de limitação do poder com fins garantísticos."2

\footnotetext{
${ }^{1}$ FERREIRA FILHO, Manoel Gonçalves. Principios fundamentais de direito constitucional. 2. ed. São Paulo: Saraiva, 2010. p. 3-4.

${ }^{2}$ MATTEUCCI, N. Organizzazione del potere e libertá. Storia des Constituzionalismo Moderno. Torino, 1978 apud CANOTILHO, José Joaquim Gomes. Direito Constitucional e Teoria da Constituição. 7. ed. Lisboa: Almedina, 2003. p. 51.
} 
Ainda prosseguindo na lição de Canotilho, "o conceito de constitucionalismo transporta, assim, um claro juízo de valor. É, no fundo, uma teoria normativa da politica, tal qual a teoria da democracia ou a teoria do liberalismo."

É certo que o constitucionalismo moderno trouxe não somente um, mas um feixe essencial de princípios $^{4}$ sobre os quais o arranjo político de nossa sociedade se desenvolveu. Contudo, o ponto de partida deste trabalho repousa na análise de um deles, a chamada doutrina ou teoria da separação de poderes, fundamental à consecução do fim maior subjacente ao movimento constitucionalista dos séculos XVII e XVIII, a limitação do poder por meio de um modelo de separação de funções.

Para chegarmos à questão central desta dissertação faz-se necessário adentrar nos contornos desta separação funcional do poder do Estado para que possamos notar a alteração fundamental sentida no âmbito do Poder Judiciário e suas implicações com os cânones da democracia.

A arquitetura estatal da separação tripartite dos poderes, consagrada pela obra de Montesquieu, com a proeminência do Poder Legislativo em face dos Poderes Executivo e Judiciário, certamente sofreu alterações fundamentais, passados mais de dois séculos de sua formulação clássica.

Segundo Manoel Gonçalves Ferreira Filho, “o ponto central da diferença é predomínio do Executivo, que, absorvendo em boa parte o campo de deliberação do Legislativo, se transformou em Governo"

Este avanço da função executiva registrado predominantemente no período pós-primeira e segunda guerras mundiais se deve em grande parte à mudança de paradigma do Estado de viés Liberal para um chamado Estado Social.

\footnotetext{
${ }^{3}$ CANOTILHO, José Joaquim Gomes. Direito Constitucional e Teoria da Constituição. 7. ed. Lisboa: Almedina, 2003. p. 51.

${ }^{4}$ J. J. Gomes Canotilho traz como dimensões fundamentais ao constitucionalismo moderno os seguintes aspectos “(1) ordenação jurídico-política plasmada num documento escrito; (2) declaração, nessa carta escrita, de um conjunto de direitos fundamentais e do respectivo modo de garantia;(3) organização do poder politico segundo esquemas tendentes a torná-lo um poder limitado e moderado." (CANOTILHO, José Joaquim Gomes. Direito Constitucional e Teoria da Constituição. 7. ed. Lisboa: Almedina, 2003. p. 52).

${ }^{5}$ FERREIRA FILHO, Manoel Gonçalves. Princípios fundamentais de direito constitucional. 2. ed. São Paulo: Saraiva, 2010. p. 266.
} 
Com o advento do Estado-Providência ou Estado-Social há uma mudança de foco, principalmente sob o aspecto da existência de uma crise de eficiência do Poder Legislativo aliada à atuação mais célere do Poder Executivo, seja no campo de atuação legislativa seja na tomada de medidas administrativas destinadas a atender aos anseios da sociedade. ${ }^{6}$

De acordo com Rubens Beçak "o século XX demonstrou que em todos os Estados do mundo, qualquer que seja o regime, o Executivo 'furtou' do Legislativo sua tarefa institucional de origem, qual seja o legislar,"

A lição extraída do parágrafo acima é precisa e constata certamente a principal mudança sofrida nesta arquitetura política concebida nos séculos XVII e XVIII: o Poder Executivo deixou de ser sinônimo de função meramente executiva para abarcar outras funções, em especial a função legislativa.

O avanço das funções do Poder Executivo é constatado de forma clara pelos principais pensadores da Teoria do Estado e Direito Constitucional, contudo, seria esta a única mudança importante ocorrida dentro desta arquitetura do Poder?

O professor Nelson Saldanha, ao se questionar se existiria um regime em que o Judiciário se destacaria, não crê nesta possibilidade e coloca a questão no plano retórico, como na famosa expressão governo de juízes ${ }^{8}$.

Contudo, será que a afirmação do autor subsiste?

Parece-nos claro que, sobretudo na experiência brasileira pós-Constituinte de 1988, há um enorme avanço da função exercida dentro das esferas de atuação do Judiciário, o que pode levar a afirmação acima de um plano retórico para um plano factível, dado o avanço substancial desta função estatal, e nisto reside a fundamental transformação que nos

\footnotetext{
${ }^{6} \mathrm{Na}$ análise de Clèmerson Merlin Cleve, "com o Estado Social foram alargadas as funções exercidas pelo poder público. O Executivo assume boa parte das novas atividades recentemente conquistadas pelo Estado" (CLEVE, Clèmerson Merlin. Atividade Legislativa do Poder Executivo. 2. ed. São Paulo: RT, 2000. p. 51), e, ainda segundo o autor, "Nesse tipo de Estado, duas variáveis simultâneas manifestam-se. Em primeiro lugar, a função legislativa atua como jamais atuou. O número de leis aumenta consideravelmente. Por outro lado, o Estado age cada vez mais por meio de outros instrumentos que não a lei." (Idem, ibidem)

${ }^{7}$ BEÇAK, Rubens. A Hipertrofia do Executivo Brasileiro: o impacto da Constituição de 1988. São Paulo: Própria, 2007. p. 43.

${ }^{8}$ SALDANHA, Nelson. O Estado moderno e a separação de poderes. São Paulo: Saraiva, 1987. p. 117.
} 
aproxima da análise da hipótese aqui suscitada, sobre a existência de uma possível tensão entre a chamada atuação ativista do poder judiciário e a democracia.

Se por um lado é certo que a função de concretizar estes direitos herdados do Estado Social coube ao Poder Executivo, é certo também que o Poder Judiciário passou a ganhar espaço e importância como fiscalizador desta implementação de direitos, e principalmente, o que se nota nas últimas décadas, como agente positivo destas políticas públicas, seja sindicando seu fiel cumprimento, seja contribuindo a estas prestações positivas por meio de decisões que tem obrigado o Estado a fornecer os meios necessários para a efetivação destes direitos.

Esse processo de mudança de predominância dos poderes, com um paulatino esvaecimento da função legiferante pelo Poder Legislativo e a hipertrofia do Poder Executivo assumindo o comando de fato da legiferação, fenômeno que se percebe com clareza em nosso contexto nacional, é com certeza uma das alterações fundamentais na dinâmica e equilíbrio da fórmula da Separação dos Poderes, e, ao lado desta transformação, o debate sobre os lindes da atuação contemporânea do Poder Judiciário parece consistir naquela que seja talvez a mais recente e importante transformação da dinâmica do Poder.

No mesmo fluxo histórico em que a configuração do Poder Executivo se alterou substancialmente, o Poder Judiciário também assumiu novas feições.

Contudo, e nisto reside o ponto fundamental que buscaremos explorar, nas últimas décadas do século XX e no início do século XXI, esta mudança no perfil do Poder Judiciário, com uma atuação mais ampla e por assim dizer firme nesta sua atividade de convalidador ou não da vontade geral expressa na lei, usando a terminologia emprestada do excerto acima colacionado, parece ter aumentado de tal forma que suas decisões, passaram a adentrar o campo de funções típicas e precípuas dos outros Poderes clássicos, no caso Executivo e Legislativo.

Dentro da análise desta mudança de perfil do Poder Judiciário, o recorte a ser adotado nesta Dissertação abordará fundamentalmente, como fatores de expansão de sua atividade, aspectos que podem ser agrupados em dois fatores fundamentais. 
O primeiro fator consiste no desenvolvimento dos mecanismos e técnicas de controle judicial de constitucionalidade, sobretudo com as inovações trazidas pela Constituição de 1988, pelas emendas constitucionais 3/1993 e 45/2004, e, pelas Leis 9.882/99 e 9.868/99, e a tendência de predominância da abstrativização e concentração de nosso modelo de controle de constitucionalidade, alcançando uma amplitude nunca dantes vista na história jurídico-constitucional brasileira.

O segundo fator reside na característica de nosso texto constitucional de 1988, permeado por cláusulas abertas e princípios cujos conteúdos apresentam no mais das vezes baixa densidade normativa, incorporando valores e conteúdos morais que permitem ao intérprete aplicador do texto constitucional larga margem interpretativa, trazendo por consequência parâmetros por vezes imprecisos e de extrema maleabilidade ao nosso bloco de constitucionalidade.

A conjugação destes dois elementos, conforme passaremos a explorar nos capítulos finais desta dissertação, somada a fatores como uma valorização de correntes moralistas ou póspositivistas do Direito, a crise do próprio modelo representativo da democracia tem tornado o Poder Judiciário o foro de debate de questões fundamentais da sociedade, as quais outrora ligavam-se fundamentalmente e exclusivamente ao debate parlamentar, travado sobretudo na esfera legislativa, sob a égide do princípio democrático.

Este trabalho buscará por meio da discussão de ideias postadas em posições antagônicas responder à questão: esta nova configuração do Poder Judiciário, encarada em seu viés mais radical, denominada por parte respeitável da doutrina como ativismo judicial, traria conflitos aos postulados democráticos, sobretudo sob o aspecto da chamada democracia representativa, ou em verdade, não traria tensão entre esta nova configuração do Poder Judiciário e os cânones de uma democracia, correspondendo a nada mais do que uma nova lógica de desenvolvimento das relações jurídico estruturantes do Estado?

Para uma respeitável parte da doutrina, a atuação restrita de controlador da conformidade do ordenamento infraconstitucional aos parâmetros da Constituição de certa forma foi deixada de lado para que os Tribunais superiores, em especial dentro do recorte que pretende este estudo, nosso Supremo Tribunal Federal, passassem ao campo da legiferação positiva e do intervencionismo exacerbado em questões afetas ao campo das opções 
políticas ligadas à escolha soberana dos cidadãos, ainda que feita dentro de uma democracia representativa.

Dentre aqueles que se filiam a este entendimento, trazemos o escólio do professor Elival da Silva Ramos em sua obra Ativismo Judicial: parâmetros dogmáticos:

\begin{abstract}
Por ativismo judicial deve-se entender o exercício da função jurisdicional para além dos limites impostos pelo próprio ordenamento que incumbe, institucionalmente, ao Poder Judiciário fazer atuar, resolvendo litígios de feições subjetivas (conflitos de interesse) e controvérsias jurídicas de natureza objetiva (conflitos normativos) ${ }^{9}$.
\end{abstract}

Consoante o conceito trazido por Elival da Silva Ramos, podemos observar que para a parcela do pensamento jurídico que se filia ao entendimento de que haveria hoje um chamado "ativismo judicial", as críticas dirigidas a esta postura do Poder Judiciário não se constituem em uma simples reação a uma alteração natural e esperada da função judicial tal como concebida pelos pais da doutrina da separação de poderes, mas sim a um desvio de conduta dentro dos parâmetros necessários de atuação do Poder Judiciário.

Embora a obra do professor da Faculdade de Direito do Largo de São Francisco adentre o tema sob os aspectos dogmáticos do Direito Constitucional, é certo que esta mesmo questão se coloca em debate sob um viés do direito constitucional mais afeto à tensão entre princípios caros a este ramo do direito, o equilíbrio entre um Estado formado nas bases de uma democracia representativa, com todos os temas que são parte integrante dela, em especial o primado da legalidade, em face desta nova, por assim dizer, atuação do Poder Judiciário.

No curso dos próximos capítulos, se desenvolverá o necessário debate de ideias entre aqueles que advogam por uma visão restritiva da função jurisdicional, pois enxergam neste chamado ativismo judicial uma atividade nociva aos postulados democráticos e a princípios caros a um Estado erigido fundamentalmente sob uma democracia de viés representativo, e aqueles, que vislumbram nesta nova atuação do poder judiciário nada mais do que um fortalecimento da democracia sob o viés de um constitucionalismo mais adequado à realidade atual.

\footnotetext{
${ }^{9}$ RAMOS, Elival da Silva. Ativismo Judicial: parâmetros dogmáticos. São Paulo: Saraiva, 2010. p. 129
} 
Nesta linha de abordagem, caberá uma parte importante deste trabalho à análise dos apontamentos feitos por Elival da Silva Ramos, Conrado Hübner Mendes, Jürgen Habermas, John Hart Ely, e outros autores do constitucionalismo nacional e estrangeiro, sobre esta suposta tensão existente.

A visão habermasiana, dentre outros pontos a serem tratados no capítulo oportuno, pugna por um tribunal constitucional que deve assegurar a "autodeterminação deliberativa da elaboração do direito" 10 , sendo fator de contenção à atuação jurisdicional, o que cabe ser analisado de forma mais aprofundada no respectivo capítulo.

Ponto fundamental da teoria de Habermas reside em sua crítica, com foco na prática do Tribunal Constitucional alemão, sobre a utilização de critérios de sopesamento de valores no âmbito de suas decisões.

Embora a análise do pensador alemão tenha como campo de observação o Tribunal Constitucional Alemão, não restam dúvidas de que sua crítica é útil à análise do tema no contexto brasileiro, principalmente em virtude do aumento da utilização destes critérios, em grande parte importados, e aqui analisaremos se esta importação se faz de forma correta ou às avessas, do direito constitucional alemão.

É importante a transcrição abaixo, da lavra dos professores Virgílio Afonso da Silva e Conrado Hübner Mendes:

\begin{abstract}
O sopesamento ou ponderação, é um critério que nada mais é do que uma forma pseudo-objetiva de canalizar as preferências pessoais do aplicador do direito. A partir dessa visão, o sopesamento apenas mascara uma substituição de posições jurídicas que podem ser igualmente sustentáveis: substitui-se a decisão do legislador, que, ao criar uma lei, expressa a sua forma particular de interpretar a constituição, pela opinião alternativa do juiz sobre o mesmo problema ${ }^{11}$.
\end{abstract}

\footnotetext{
${ }^{10}$ ROCHA, Jean Paul C. Veiga da. Separação dos Poderes e Democracia Deliberativa. In: NOBRE, Marcos; TERRA, Ricardo. (Orgs.). Direito e Democracia: um guia de leitura de Habermas. São Paulo: Malheiros Editores, 2008. p. 182.

${ }^{11}$ MENDES, Conrado Hübner; SILVA, Virgílio Afonso da. Habermas e a Jurisdição Constitucional. In: NOBRE, Marcos; TERRA, Ricardo. (Orgs.). Direito e Democracia: um guia de leitura de Habermas. São Paulo: Malheiros Editores, 2008. p. 213.
} 
Ainda em sede introdutória, cabe trazer, como contraponto a visão mais restritiva sobre atuação judicial em face dos parâmetros democráticos, na obra de autoria de Bruce Ackerman, Nós, O Povo Soberano: fundamentos do direito constitucional: o professor da Universidade de Yale traz importantes considerações sobre a legitimidade da Corte, no caso sendo seu estudo focado na Suprema corte norte-americana, colocando em xeque a suposta afronta a primados democráticos sustentada por aqueles que visualizam na atuação das supremas Cortes um ativismo judicial.

Segundo Ackerman, "a Suprema Corte, no seu exercício interpretativo, torna-se um aspecto fundamental de empreendimento da soberania popular voltada para o futuro" ${ }^{\prime 2}$.

Explicitando melhor o que busca demonstrar Ackerman, ao enfrentar questões que outrora era afetas unicamente ao debate político-legislativo, o Poder Judiciário parece suprir uma lacuna de representatividade existente nos períodos de política normal, em que não há participação dos cidadãos no debate parlamentar.

Não haveria um déficit democrático nesta atuação, mas sim um necessário preenchimento desta lacuna, sendo o Judiciário um espaço de deliberação legítimo para que se preservem os próprios interesses da população quando esta não participa de forma ativa do processo legislativo.

Por acaso não seria este o quadro que verificamos quando o Supremo Tribunal Federal enfrenta questões como o aborto de fetos anencéfalos ou a união homoafetiva, dentre outros tormentosos temas de nosso contexto político-social?

Haveria espaço e participatividade suficientes para que o povo exercitasse a deliberação sobre estes temas no âmbito do processo parlamentar?

Com base nestas premissas teóricas formuladas por estes pensadores em comento bem como pelos estudos de eminentes autores nacionais como Rubens Beçak, Elival da Silva Ramos, Manoel Gonçalves Ferreira Filho, dentre outros, teremos o material necessário ao enfrentamento da questão.

\footnotetext{
${ }^{12}$ ACKERMAN, Bruce. Nós, o povo soberano: Fundamentos do Direito Constitucional. Mauro Raposo de Mello (Trad.). Belo Horizonte: Del Rey, 2006. p. 369.
} 
Não se busca com este trabalho adentrar a justiça ou conveniência do conteúdo material desta nova atuação da função judicial, mas sim, com base nestes pontos trazer a análise das críticas necessárias, bem como, a leitura de propostas para o equilíbrio desta nova realidade com os postulados democráticos, para uma análise para além da crítica.

Nas palavras de Rubens Beçak, "o processo de deslocamento da atividade legislativa para os Tribunais parece vir se acelerando e, sobretudo, configurando processo de latitude mundial, de certa forma inexorável" ${ }^{\prime 13}$.

A observação acima é precisa, e talvez, esta seja uma mudança de perfil que a história mostrará irreversível, cabendo um olhar crítico necessário e ao mesmo tempo construtivo, e não meramente reativo a esta nova realidade

Feitas estas considerações introdutórias, passaremos no capítulo seguinte a uma abordagem sobre o princípio da separação de poderes, elo e paradigma comparativo entre o passado fundante do constitucionalismo moderno e as transformações no arquétipo estatal, para que então enfrentemos os temas ativismo judicial e democracia.

${ }^{13}$ Congresso Nacional do CONPEDI, 17., 2008, Salvador, Anais, p. 2768. 


\section{BREVES APONTAMENTOS SOBRE A TEORIA DA SEPARAÇÃO DE PODERES}

Como ponto de partida de nosso estudo, cabe a incursão sobre o princípio fundamental ao constitucionalismo moderno, a separação de poderes.

Sendo o fundamento deste constitucionalismo moderno a limitação do poder, pode-se afirmar que o princípio da separação de poderes foi a principal ferramenta concebida pelos pensadores do Direito Constitucional e da Teoria Política como forma de realização deste fim maior.

Embora a Declaração dos Direitos da Virgínia datada de 1776, que poucos dias depois serviria de base ao nascimento da Declaração de Independência dos Estados Unidos da América preceda a declaração francesa dos Direitos do Homem e do Cidadão de 1789, e contenha importante disposição que declara a necessária separação entre Poder Judiciário, Legislativo e Executivo $^{14}$, certamente a declaração francesa, mormente por seu caráter universalizante e expresso, pode ser tida como principal marco que erigiu o princípio em status de dogma intangível, ao menos em seu conteúdo formal, e condição sine qua non para o constitucionalismo.

Esta condição essencial do princípio se comprova quando observamos a já tão mencionada Declaração dos Direitos do Homem e do Cidadão, ao estatuir em seu artigo 16: “A sociedade em que não esteja assegurada a garantia dos direitos nem estabelecida a separação dos poderes não tem Constituição."

O princípio tão caro ao nosso constitucionalismo comumente é citado como presente nos antecedentes remotos do período helênico, ao ver na República de Aristóteles um esboço da doutrina desenvolvida com maior veemência no período de revoluções liberais dos séculos XVII e XVIII.

\footnotetext{
${ }^{14}$ Nota-se a clara intenção dos pais fundadores ao erigir a separação de poderes do Estado, como forma de controle do exercício do poder, ao dispor no art. $5^{\circ}$ da Declaração dos Direitos da Virginia: "O poder legislativo e o poder executivo do estado devem ser distintos e separados da autoridade judiciária; e a fim de que também eles de suportar os encargos do povo e deles participar possa ser reprimido todo o desejo de opressão dos membros dos dois primeiros devem estes em tempo determinado, voltar a vida privada, reentrar no corpo da comunidade de onde foram originariamente tirados; os lugares vagos deverão ser preenchidos por eleições, frequentes, certas e regulares".
} 
Em que pese a tão comum afirmação presente em diversos manuais e obras sobre direito constitucional, nos filiamos à lição do professor Manoel Gonçalves Ferreira Filho, crendo que embora parte da doutrina veja uma contribuição helênica ao princípio da separação de poderes, não haveria menção expressa à obra do pensador estagirita nos trabalhos de Locke, Montesquieu e outros pensadores do período moderno que delinearam a separação funcional do poder tal qual concebida até os dias atuais ${ }^{15}$.

A principal característica herdada do pensamento grego e romano reside sobretudo não em uma teoria de separação de poderes ou em contribuição à sua formulação, mas sim no chamado governo misto ${ }^{16}$.

A divisão das funções estatais nos moldes atribuídos a Locke, Montesquieu e ao consagrado nas revoluções inglesa e francesa, ao contrário daquilo que se tornou lugarcomum em parte dos manuais de Teoria do Estado e Direito Constitucional, não foi formulada durante o período de efervescência política e cultural gregas ou romanas.

De acordo com o que menciona o professor Nelson Saldanha "o pensamento grego se preocupava profundamente com a questão do governo ideal em termos de adequação entre mérito e poder, ou entre justiça e ordem." ${ }^{, 17}$ Prossegue ainda Nelson Saldanha: "a questão dos poderes, tal como seria concebida e debatida no Ocidente contemporâneo, não foi propiciada pelo ordenamento político da polis" ${ }^{18}$.

O pensamento da era antiga, de alguma forma traz contributo essencial ao arranjo político constitucional da era moderna, porém, o faz sobretudo na ideia de um governo sob a égide de leis que se sobrepõe à vontade do governante, como garantia aos cidadãos deste Estado.

Nas palavras do professor Maurice J. C. Vile:

The greatest contribution os ancient thought in the sphere in which we are concerned, was it emphasis upon the rule of law, upon te sovereignty of law over

\footnotetext{
${ }^{15}$ FERREIRA FILHO, Manoel Gonçalves. Princípios Fundamentais do Direito Constitucional. 2. ed. São Paulo: Saraiva, 2010. p. 252.

${ }^{16}$ VILE, Maurice J. C. Constitutionalism and the separation of powers. $2^{\mathrm{a}}$. ed. Indianapolis: Liberty Fund., 1998. p. 25.

${ }_{17}^{17}$ SALDANHA, Nelson. O Estado moderno e a separação de poderes. São Paulo: Saraiva, 1987. p. 91.

${ }^{18}$ Idem, ibidem. p. 91.
} 
the ruler. It emphasized the necessity of settled rules of law which would govern the life os the State, give it stability and assure "justice for equals",19.

O ponto de partida que importa ao estudo do constitucionalismo moderno, com todas as vênias e homenagens ao pensamento helênico, fundamental não só à teoria política como a todo o pensamento moderno ocidental, reside nas formulações de John Locke, constantes do Segundo Tratado do Governo Civil, e naquela que é considerada a obra fundamental sobre o tema, O Espírito das Leis, de Montesquieu.

Em Segundo Tratado do Governo Civil, publicado em 1690, anterior à publicação de O Espírito das Leis, é proposta uma divisão funcional do poder, na qual Locke sugere a existência de um Poder Executivo, um Poder Legislativo e um Poder Federativo ${ }^{20}$.

Este terceiro poder chamado de Federativo, estranho ao arquétipo consagrado ao longo dos tempos sobre uma divisão tripartite, em verdade se revela como uma faceta do Poder Executivo, destinado aos aspectos externos ou internacionais do governo.

O capítulo XII do Segundo Tratado do Governo Civil sintetiza bem a distinção de funções entre o chamado Poder Executivo e Poder Federativo, situando-os contudo dentro de um mesmo ente.

\footnotetext{
Esses dois poderes, o executivo e o federativo, embora sejam realmente distintos entre si, compreendendo um a execução das leis municipais da sociedade dentro de seus próprios limites sobre todos os que dela fazem parte, e o outro, a gestão da segurança e do interesse do público externo, com todos aqueles de que ela pode receber benefícios ou injúrias, quase sempre estão unidos ${ }^{21}$.
}

Não havia no pensamento do mestre inglês menção a um Poder Judiciário, fator este que torna a teoria de Montesquieu mais próxima à realidade do constitucionalismo moderno do mundo ocidental, e certamente, foi um dos fatores que o tornou conhecido como o pai da doutrina, embora outros autores, sobretudo Locke, tenham formulado arquétipos de divisão funcional do poder estatal antes da formulação do pensador francês.

\footnotetext{
${ }^{19}$ VILE, Maurice J. C. Constitutionalism and the separation of powers. $2^{\mathrm{a}}$. ed. Indianapolis: Liberty Fund., 1998. p. 25.

${ }^{20}$ FERREIRA FILHO, Manoel Gonçalves. Principios Fundamentais do Direito Constitucional. 2. ed. São Paulo: Saraiva, 2010. p. 253.

${ }^{21}$ LOCKE, John. Dois tratados sobre o governo. Julio Fischer (Trad). 2a . ed. São Paulo: Martins Fontes, 2005. p. 516.
} 
A concepção de um poder incumbido da função de julgar no pensamento de Locke situavao dentro do âmbito do próprio poder legislativo, não se podendo falar na existência de um Poder Judiciário, dentro de uma concepção de matiz inglesa de uma função meramente de expressão do Direito, tal qual exercida por aqueles que elaboravam as leis ${ }^{22}$.

O primado do Legislativo no pensamento lockeano, bem como no pensamento dos séculos XVII e XVIII, afastava em sua maior parte a concepção de uma função jurisdicional nos moldes concebidos em nossa atualidade, uma função judicial que apenas proclamava os comandos legais aos casos concretos, e por isso mesmo, desnecessária uma maior estruturação institucional em torno de juízes ou Cortes.

Duas passagens extraídas da obra de Locke são de extrema importância e ilustram com clareza a síntese do pensamento do autor inglês, de um lado apontando a predominância do Poder Legislativo, por outro, demonstrando a ausência da formulação de um Poder Judiciário independente, sendo a solução de conflitos uma mera atribuição do próprio Legislativo.

\begin{abstract}
Esse legislativo é não apenas o poder supremo da sociedade política, como também é sagado e inalterável nas mãos em que a comunidade o tenha antes depositado; tampouco pode edito algum de quem quer que seja, seja de que forma concebido ou por que poder apoiado, ter força e obrigação de lei se não foi sancionado pelo legislativo escolhido e nomeado pelo público ${ }^{23}$.

Em segundo lugar, a autoridade legislativa, ou suprema, não pode arrogar-se o poder de governar por meio de decretos arbitrários extemporâneos, mas está obrigada a dispensar justiça e a decidir acerca dos direitos dos súditos por intermédio de leis promulgadas e fixas, e de juízes conhecidos e autorizados ${ }^{24}$.
\end{abstract}

Fica claro o primado do Legislativo e a impossibilidade de se falar em Poder Judiciário no pensamento de John Locke.

A contribuição Locke à formulação de uma doutrina tendente a organizar o exercício das funções estatais de forma a colimar o alcance do ideal maior ínsito ao ideário comum ao

\footnotetext{
${ }^{22}$ FERREIRA FILHO, Manoel Gonçalves. Princípios Fundamentais do Direito Constitucional. 2. ed. São Paulo: Saraiva, 2010. p. 253.

${ }^{23}$ LOCKE, John. Dois tratados sobre o governo. Julio Fischer (Trad). 2a . ed. São Paulo: Martins Fontes, 2005. p. 503.

${ }^{24}$ Idem, ibidem. p. 506-7.
} 
período de revoluções, seja na Grã-Bretanha, seja na França, é inegável, porém, é com Montesquieu que nos aproximamos mais, ao menos no plano nominal, uma vez que as feições do Judiciário concebido pelo pensador francês eram de um exegeta preso à literalidade da lei, fruto do legislativo soberano, da teoria da separação dos poderes.

A obra do iluminista francês se dedica, sobretudo em seu Livro XI, à construção de uma teoria de separação de funções estatais na qual podemos conceber três poderes distintos, independentes e harmônicos entre si, o Poder Executivo, Poder Legislativo e Poder Judiciário.

Antes mesmo de adentrarmos a análise da obra de Montesquieu, cabe a necessária menção à concepção inglesa presente na revolução de 1689, na qual, sobretudo com o advento do Act of Settlement a Inglaterra de então, antes mesmo da publicação da célebre obra, $\mathrm{O}$ Espírito das Leis, já contava com uma divisão tripartite Legislativo, Executivo e Judiciário.

Na Inglaterra do período da revolução de 1689 havia um Poder Legislativo, independente do Monarca, bem como um Poder Judiciário, ainda não independente, mas vinculado ao Monarca.

O chamado Act of Settlement, de 1701, completa o quadro inglês de uma divisão tripartite, semelhante em parte ao que seria disposto por Montesquieu algumas décadas depois, pois torna o Poder Judiciário desvinculado da vontade do Monarca, juntando-se agora ao parlamento que com o Bill of Rights de 1689 tornara-se um Poder Legislativo não mais atrelado ao poder monárquico.

De acordo com Manoel Gonçalves Ferreira Filho, “os juízes que até então podiam ser livremente exonerados pelo rei, passaram a não ser dispensados, exceto se condenados por alguma falta grave ou por deliberação de ambas as casas do parlamento"25.

A Revolução Inglesa precede em aproximados cem anos a Revolução Francesa, bem como em algumas décadas o lançamento da obra mestra de Montesquieu, já prevendo, tal qual

${ }^{25}$ FERREIRA FILHO, Manoel Gonçalves. Principios Fundamentais do Direito Constitucional. 2. ed. São Paulo: Saraiva, 2010. p. 254. 
estaria contido na Declaração dos Direitos da Virginia de 1776 e na Declaração dos Direitos do Homem e do Cidadão, uma separação de poderes em certa medida similar à fórmula clássica consagrada anos após com a declaração universalizante nascida na França, sobretudo pela figura de um Poder Judiciário independente, com o advento do Act of Settlement.

Completando este quadro de principais fontes históricas da doutrina da separação dos poderes, chegamos à obra que tornou célebre tal formulação, Do Espírito das Leis.

Não sem propósito, Montesquieu no capítulo VI do Livro XI, denominado "Da Constituição da Inglaterra", busca formular com base na análise da Constituição Inglesa uma estrutura visando evitar o abuso do Poder, o que como já exposto, constitui-se em um dos pilares centrais do período de revoluções no qual se insere a Revolução Francesa.

Embora Montesquieu busque no exemplo inglês dar à França um modelo de estruturação do Estado baseado na separação tripartite das funções estatais, em verdade, a obra do Mestre francês não refletia exatamente o real espectro da sociedade inglesa da época em que fora publicado Do Espírito das Leis.

Segundo o professor Manoel Gonçalves Ferreira Filho, embora a publicação do livro em 1748 tenha sido precedida por um período de viagens entre 1728 e 1731, no qual pôde ter contato com a realidade das instituições inglesas, Montesquieu parece desconhecer que na Inglaterra de então já se estabelecia a figura de um Primeiro-Ministro como figura chefe do Executivo, e não do monarca como descrito em sua obra ${ }^{26}$.

Da mesma forma, o professor Maurice J. C. Vile chega a afirmar: "When Montesquieu wrote of "England" here he was writing of an imaginary country, as in the Letters persanes: "I'Angleterre de Montesquieu c'est l'Utopie, c'est un pays de rêve"27.

\footnotetext{
${ }^{26}$ FERREIRA FILHO, Manoel Gonçalves. Princípios Fundamentais do Direito Constitucional. 2. ed. São Paulo: Saraiva, 2010. p. 255.

${ }^{27}$ VILE, Maurice J. C. Constitutionalism and the separation of powers. $2^{\mathrm{a}}$. ed. Indianapolis: Liberty Fund., 1998. p. 89.
} 
O Barão de La Brède parece não haver cometido equívocos casuais, mas sim descrito uma espécie de modelo ideal que deve ser considerado por seus méritos ${ }^{28}$, e não observado através de divagações sobre sua correspondência exata ou não ao modelo inglês descrito.

Mostra-se correta a análise de Manoel Gonçalves Ferreira Filho no sentido de que Montesquieu "tomando a Constituição inglesa como pretexto, procura "vender" uma fórmula ou receita política, tendo em vista a renovação das instituições francesas, especialmente" 29 .

Montesquieu, assim como os outros autores de sua época, eram portadores de um discurso político destinado ao debate de ideias e posições da sociedade de então, que em especial se encontrava em um momento de efervescência política.

É sob este aspecto que devemos observar sua obra, e neste viés, sua contribuição mostrouse original e de importância central para o desenvolvimento do tema, sobretudo na consagração deste dogma e pilar fundamental do constitucionalismo moderno no qual sua fórmula, ao contrário das outras elaboradas por seus predecessores, mostrou-se vitoriosa.

O grande legado de Montesquieu no âmbito da chamada doutrina da separação dos poderes reside em alocar três diferentes funções, Legislativa, Executiva e Judiciária, outorgadas a titulares diferentes, de forma que, sejam independentes e ao mesmo tempo harmônicas entre si, que possuam mecanismos de controle recíproco que permitam evitar que uma se arrogue poderes absolutos ou deles abuse.

Esta gênese de seu pensamento, mesmo passados aproximadamente três séculos, mantémse atual, na medida em que, embora tenham ocorrido transformações diversas nesta arquitetura do poder, prevalece a ideia de um sistema de freios e contrapesos, mesmo que com roupagens sofisticadas pelo implemento de diversas ferramentas de controle desenvolvidas neste decorrer de centenas de anos entre a formulação clássica e a atual.

\footnotetext{
${ }^{28}$ VILE, Maurice J. C. Constitutionalism and the separation of powers. $2^{\mathrm{a}}$. ed. Indianapolis: Liberty Fund., 1998. p. 89.

${ }^{29}$ FERREIRA FILHO, Manoel Gonçalves. Principios Fundamentais do Direito Constitucional. 2a. ed. São Paulo: Saraiva, 2010. p. 255.
} 
O pensador francês inicia o Capítulo VI do Livro XI, da seguinte forma: "Há em cada Estado três tipos de poder: o Poder Legislativo, o poder executivo das coisas que dependem do direito das gentes e o poder executivo das coisas que dependem do direito civil" 30 .

Ainda prosseguindo com a necessária citação da obra, no parágrafo seguinte Montesquieu situa como ponto de partida de seu capítulo as respectivas funções destes três poderes:

\begin{abstract}
Pelo primeiro, o príncipe ou o magistrado produz as leis para um certo tempo ou para sempre e retifica ou ab-roga aquelas que são produzidas. Mediante o segundo, ele produz a paz ou a guerra, envia ou recebe embaixadores, estabelece a segurança, previne as invasões. Mediante o terceiro, ele pune os crimes e julga as diferenças dos indivíduos. Chamaremos este último de poder judiciário e o outro simplesmente de poder executivo do Estado ${ }^{31}$.
\end{abstract}

Neste ponto já se percebe a inovação do pensamento de Montesquieu em relação a Locke.

Ao contrário do pensador inglês, ele situa a figura do Poder Judiciário de forma independente das demais, e não como uma parte do Poder Legislativo, tal qual preconizada por Locke.

A função jurisdicional mostra-se materialmente limitada aos mandamentos do poder legiferante, embora Montesquieu tenha colocado a função jurisdicional em um plano separado das demais: esta seria, de acordo com a célebre frase a ele atribuída, a boca que pronuncia a lei.

Vale fazer a citação da célebre frase que sintetiza a opção por um modelo jurisdicional filiado à Escola de Exegése: “os juízes de uma nação são, como dissemos, apenas a boca que pronuncia as palavras da lei, seres inanimados que não podem moderar sua força, nem seu rigor" 32 .

Muito embora a concepção de jurisdição se atenha a uma acanhada atuação, sob os auspícios da Escola de Exegese, um dos principais pontos na obra de Montesquieu que a

\footnotetext{
${ }^{30}$ MONTESQUIEU, Charles Louis de Secondat, baron de la Brède et de. O Espirito das leis. Edson Bini (Trad.). São Paulo: Edipro, 2004. p 189.

${ }^{31}$ Idem, ibidem. p. 189.

${ }^{32}$ Idem, ibidem. p. 195.
} 
situa como fundamental e inovadora em relação aos seus antecessores, é a atenção outorgada ao Poder Judiciário.

Segundo Vile:

It is clear, however, that Montesquieu did not invent the doctrine of the separation of powers, and that much of what he had to say in Book XI Chapter 6 of the De l'Espirit des Lois was taken over from contemporary English writers, and from John Locke. Montesquieu, it is true, contributed new ideas to the doctrine; he emphasized certain elements in it that had not previously received such attention, particulary in relation to the judiciary, and he accorded the doctrine a more important position than did previous writers. ${ }^{33}$

Voltando nossa análise à formulação de Montesquieu, a preocupação explícita em sua obra com a separação dos poderes revela-se na garantia da liberdade política dos indivíduos.

Esta liberdade tem como ferramenta de garantia justamente a separação funcional do poder, de forma que as funções principais exercidas pelo Estado coloquem-se em mãos diferentes, evitando os abusos de poder decorrentes da concentração.

\begin{abstract}
Não há liberdade alguma se o poder judiciário não for separado do poder legislativo e do executivo. Se estivesse unido ao poder legislativo, o poder sobre a vida e a liberdade dos cidadãos seria arbitrário, pois o juiz seria legislador. Se estivesse unido ao poder legislativo, o poder sobre a vida e a liberdade dos cidadãos seria arbitrário, pois o juiz seria legislador. Se estivesse unido ao poder executivo, o juiz poderia deter a força de um opressor.

Tudo estaria perdido se o mesmo homem ou o mesmo corpo de principais ou dos nobres, ou do povo, exercesse esses três poderes: o de produzir leis, o de executar resoluções públicas e o de julgar os crimes ou as convergências dos indivíduos ${ }^{34}$.
\end{abstract}

$\mathrm{Na}$ fórmula acima, embora não haja uma pureza absoluta na separação destas funções, percebe-se que seu núcleo essencial preserva-se nas mãos de cada um dos respectivos poderes: desconhecia o autor à época a legiferação em massa pelo poder executivo, e principalmente, as incursões do poder judiciário, até então exegeta, fiel à letra da lei, sobre os domínios do legislativo e executivo.

\footnotetext{
${ }^{33}$ VILE, Maurice J. C. Constitutionalism and the separation of powers. $2^{\mathrm{a}}$. ed. Indianapolis: Liberty Fund., 1998. p. 83.

${ }^{34}$ MONTESQUIEU, Charles Louis de Secondat, baron de la Brède et de. O Espírito das leis. Edson Bini (Trad.). São Paulo: Edipro, 2004. p. 191.
} 
A preocupação de Montesquieu atendia claramente aos anseios da sociedade liberal burguesa em formação nos Estados da Europa, mormente na França, na qual o modelo absolutista deveria ser afastado para dar espaço a um modelo propenso à implantação dos ideais liberais de então.

$\mathrm{O}$ modelo francês, e aqui remetemos nossa atenção novamente à disparidade existente entre a análise de Montesquieu sobre a Constituição inglesa e a realidade do país bretão, visava criar condições para que a burguesia ascendente tivesse terreno livre para seu crescimento, sem a opressão da Monarquia, que em verdade houvera rompido com a classe burguesa, impedindo a liberdade necessária ao seu desenvolvimento econômico, diferente da evolução do tema na Inglaterra, na qual as mudanças surgiram de forma paulatina e lastreada em razões diferentes ${ }^{35}$.

Segundo Paulo Bonavides, "Montesquieu interpretou preconcebidamente a Constituição inglesa para servir aos fins da revolução incipiente, ao descontentamento que lavrara contra as monarquias opressoras de direito divino" ${ }^{\text {}}$.

Críticas à parte, temos que o modelo de Montesquieu condicionava uma separação de funções como necessária à preservação da liberdade e à proteção do indivíduo, seja a que título tenha se dado este ideal.

De acordo com Rubens Beçak:

\begin{abstract}
O fundamental na teoria montesquiana foi aliar à identificação de determinada função estatal, além de seu desempenho por um poder específico do Estado, a recomendação de que não fossem atribuídas a mais de um poder cada função e, ademais, que esses Poderes desempenhassem suas funções sem imiscuírem-se nas esferas alheias ${ }^{37}$.
\end{abstract}

\footnotetext{
${ }^{35}$ Cabe aqui transcrever o escólio do professor Paulo Bonavides, na obra de referência Do Estado Liberal ao Estado Social: "Em verdade, os barões feudais, como assinalava proficientemente Laboulaye, se aliaram, nas ilhas britânicas, ao povo, para combater as pretensões do absolutismo real, precisamente ao contrário do que se deu na Europa, onde o rei teria pactuado com as classes populares para everter a independência, a liberdade e o poderio da nobreza, liquidando-a politicamente". (BONAVIDES, Paulo. Do Estado Liberal ao Estado Social. 9. ed. São Paulo: Malheiros Editores, 2009. p. 70-1). Ainda prosseguindo o mestre Paulo Bonavides: "O hiato profundo que se formou entre o rei e o povo, depois de abatida, portanto, a independência política da nobreza, deu à revolução liberal-democrática europeia feição inteiramente distinta daquela que ocorreu na Inglaterra." (Idem, ibidem ).

${ }^{36}$ BONAVIDES, Paulo. Do Estado Liberal ao Estado Social. 9. ed. São Paulo: Malheiros, 2009. p. 70.

${ }^{37}$ BEÇAK, Rubens. A separação de poderes, o Tribunal Constitucional e a Judicialização da Política. Revista da Faculdade de Direito da Universidade de São Paulo, São Paulo, v. 103, p. 329, 2008.
} 
Ainda sobre $\mathrm{O}$ Espírito das Leis, na formulação do pensador francês cabem alguns apontamentos quanto à configuração dada a estes três poderes em sua obra.

O poder judiciário, que recebera atenção especial na referida obra, seria exercido de forma não permanente, mas sim por curtos períodos de acordo com estipulação de $1 \mathrm{ei}^{38}$.

Embora haja em Montesquieu uma preocupação com a formulação de um poder judiciário, seu papel em face dos demais poderes mostrava-se diminuto, primeiro porque ao poder legislativo cabia a expressão da vontade geral do povo, por meio de um sistema representativo, e ao poder executivo, a execução desta vontade geral, estampada na produção legislativa do órgão deliberativo.

A atuação do poder judiciário de então, tal como concebido e colocado em prática na época, distancia-se diametralmente do que podemos observar na realidade atual.

Se, por um lado, enfrentamos hoje a questão do implemento de funções do poder judiciário, a assunção de novos papéis na sociedade civil e política, culminando com o que parte da doutrina denomina de ativismo judicial, apontando a tensão existente em face dos postulados democráticos, a jurisdição de Montesquieu apenas e simplesmente enunciava os comandos provenientes do poder legislativo aos casos concretos.

\footnotetext{
Mas, se os tribunais não devem ser fixos, os julgamentos devem sê-lo a tal ponto que não sejam jamais senão um texto preciso de lei. Se eram uma opinião pessoal do juiz, vivia-se na sociedade sem conhecer precisamente os compromissos que nela se contratam ${ }^{39}$.
}

Os contornos do poder judiciário de então denotavam um poder que embora esteja instituído na Constituição, se distanciava muito da realidade vista mormente a partir do século XX, após o período das grandes guerras e do advento do chamado Welfare State.

\footnotetext{
38 "O poder judiciário não deve ser concedido a um senado, permanente, mas exercido por pessoas tiradas do corpo do povo, em certos períodos do ano, da maneira prescrita pela lei, objetivando a formação de um tribunal que não deve ser mais do que o requerido pela necessidade. Dessa forma, o poder judiciário, tão terrível entre os homens, não estando ligado nem a uma certa condição, nem a uma certa profissão, torna-se por assim dizer, invisível e nulo. Não há de algum modo constantemente juízes diante dos olhos e teme-se a magistratura, e não os magistrados". (MONTESQUIEU, Charles Louis de Secondat, baron de la Brède et de. O Espírito das leis. Edson Bini (Trad.). São Paulo: Edipro, 2004. p. 191)

${ }^{39}$ Idem, ibidem. p. 191.
} 
Embora não haja na obra de Montesquieu uma subordinação do Estado-Juiz aos demais poderes, fica claro que seu papel ocupava plano secundário, pois possuía a função de apenas enunciar a letra da lei aos casos concretos, sendo ainda exercido de forma temporária, consoante a prescrição legal, mas não de forma permanente.

Este caráter, relegado ao segundo plano, do Poder Judiciário em detrimento dos poderes executivo, e fundamentalmente, do Legislativo, reforçou-se ainda mais com a consagração de ideais liberais, dos quais o próprio Montesquieu pode ser tido como um de seus autores fundamentais, bem como a formulação jurídica da visão liberal, consagrada no princípio da legalidade ${ }^{40}$.

No que toca aos demais poderes, estes poderiam ser concebidos de forma permanente, pois segundo o ilustre pensador "não são exercidos sobre nenhum indivíduo particular, sendo apenas a vontade geral do Estado e o outro apenas a execução dessa vontade geral"41.

O Legislativo possuía uma feição de índole representativa e por assim dizer, aristocrática, posto que o pensador francês não via no povo de então a capacidade para a tomada das decisões afetas a esta função deliberativa. Este mostrava-se capacitado somente para eleger seus representantes ${ }^{42}$.

Dois pontos da obra no que se refere ao Poder Legislativo merecem a transcrição, o primeiro apontando sua diferenciação face ao Executivo, incumbido da tomada das chamadas resoluções ativas, bem como, a atribuição de função semelhante ao que hoje conhecemos como veto pelo poder executivo, justamente par que servisse de mecanismo de freio e contrapeso ao poder legado ao legislativo.

\footnotetext{
${ }^{40}$ Trazemos à colação a lição do professor Manoel Gonçalves Ferreira Filho, sobre o tema: "Trata-se da supremacia do Legislativo. Este é o poder representativo. Ora, os movimentos liberais o valorizam, em detrimento do Executivo, visto como monárquico, e o Judiciário, encarado como aristocrático. Isto leva a um hierarquização dos Poderes, ficando no ápice o Legislativo. Montesquieu jamais apontou para tal supremacia, ou para uma hierarquia entre os Poderes, como se deduz da sua doutrina do equilíbrio entre os Poderes" (FERREIRA FILHO, Princípios Fundamentais do Direito Constitucional. 2. ed. São Paulo: Saraiva, 2010. p. 258). Ainda prosseguindo, o professor da Faculdade de Direito do Largo de São Francisco afirma: “A visão liberal recebeu dos juristas a conformação acabada. Esta se espelha na doutrina do Estado de Direito, cujo primeiro princípio é a legalidade. Ninguém está obrigado a fazer ou deixar de fazer o que não é determinado pela lei. Ora, a lei é obra do Legislativo. Consequência disto é estar o Executivo adstrito a atuar sub lege. E o Judiciário, a aplicar a lei (contenciosamente, embora).” (FERREIRA FILHO, Manoel Gonçalves. Princípios Fundamentais do Direito Constitucional. 2. ed. São Paulo: Saraiva, 2010. p. 258).

${ }^{41}$ MONTESQUIEU, Charles Louis de Secondat, baron de la Brède et de. O Espírito das leis. Edson Bini (Trad.). São Paulo: Edipro, 2004. p. 191.

${ }^{42}$ Idem, ibidem. p. 192.
} 
O corpo representativo não deve ser escolhido tampouco para tomar alguma resolução ativa, algo que não realizaria bem, mas para produzir leis ou para verificar se as que foram produzidas estão sendo bem postas em execução, algo que pode fazer muito bem e que inclusive não dispõe senão dele para fazer bem $^{43}$.

No que concerne as chamadas faculdades de estatuir e faculdade de ordenar, assim leciona o Barão de La Brède:

Denomino faculdade de estatuir o direito de ordenar por si mesmo, ou de corrigir o que foi ordenado por outro. Chamo de faculdade de impedir o direito de anular uma resolução tomada por qualquer outro, o que era o poder dos tribunos de Roma $^{44}$.

Estas chamadas faculdades de estatuir e de impedir, assemelhadas de certa forma com o mecanismo do veto executivo, demonstravam a preocupação de Montesquieu em evitar o acúmulo de poder, e a consequente possibilidade de que fosse utilizado de forma corrompida por seus detentores. Buscava evitar que o corpo de nobres que compunha a parcela deliberativa do poder legislasse em causa própria, sem que houvesse recurso ao alcance dos demais poderes para evitar estes abusos.

Segundo Montesquieu, "se o poder executivo não tiver o direito de suspender os empreendimentos do corpo legislativo, este será despótico, pois, como estará capacitado a outorgar-se todo o poder por ele imaginável, aniquilará os demais poderes" ${ }^{\text {, }}$.

No que concerne ao Poder Executivo, este deveria estar confiado nas mãos de um monarca, pois seu exercício pressupõe ações instantâneas que poderiam ser paralisadas caso fosse exercido por dois ou mais indivíduos, como um órgão colegiado ${ }^{46}$.

Embora houvesse mecanismos à disposição dos poderes para controle recíproco, o que se constitui em ponto fundamental de sua doutrina, a separação funcional deveria ser absoluta, como garantia da liberdade dos indivíduos.

\footnotetext{
${ }^{43}$ MONTESQUIEU, Charles Louis de Secondat, baron de la Brède et de. O Espirito das leis. Edson Bini (Trad.). São Paulo: Edipro, 2004.p. 193.

${ }^{44}$ Idem, ibidem. p. 193.

${ }^{45}$ Idem, ibidem. p. 194.

${ }^{46}$ Idem, ibidem. p. 193.
} 
As formulações transcritas nos parágrafos anteriores mostram uma divisão funcional do poder na qual, sobretudo com o aporte jurídico e dos ideais liberais, cristalizou-se a existência de três esferas fundamentais do exercício do Poder.

Uma esfera legislativa, de viés representativo, loco deliberativo do qual emana a vontade geral do povo, revestida sob o caráter de lei, calcada nos primados da legalidade e do monismo legislativo, na qual a fonte do Direito provém da norma como produto da atuação deste poder, o qual ditava a atuação dos demais.

Ao lado deste Poder Legislativo, havia, delimitados, um Poder Executivo, responsável pela execução da lei criada pelo Legislativo, sem olvidarmos de suas funções diplomáticas e de sua atuação por meio de sistemas de freios e contrapesos, e, um Poder Judiciário, de atuação por assim dizer, acanhada, como um poder responsável pela aplicação desta mesma lei aos casos e litígios concretos dentro dos limites exatos da exegese literal da norma.

Se este foi o arquétipo histórico da teoria da separação de poderes, marco fundamental do Constitucionalismo Moderno formulado com base nas premissas teóricas de Locke, Montesquieu, e nas experiências institucionais inglesa, americana e francesa, modelo que perdurou durante séculos, por certo que em diferentes nuances para cada um dos Estados e regimes políticos a que se aplicara, os influxos da história, sobretudo dos acontecimentos do século XX, passaram a mudar os pesos nesta balança do Poder.

Ao passo que na formulação de Montesquieu não havia uma clara e declarada predominância de um poder sobre os demais, o que ocorreu nos momentos históricos posteriores em que o poder legislativo tornara-se proeminente em relação aos demais, fundamentalmente no século XX, sob influência do período pós-guerra e do chamado Welfare State, há uma mudança neste arquétipo até então vigente.

O limiar do século XX assiste ao avanço do intervencionismo estatal, à mudança dos paradigmas liberais para uma atuação ativa do Estado, não mais como mero garantidor de direitos, mas sim como instrumento de efetivação dos direitos fundamentais. 
Os ideais liberais clássicos perdem terreno na medida em que surge na sociedade a contradição entre o modelo estatal abstencionista, reflexo da opção de uma classe burguesa ascendente, e a premente a necessidade de uma participação efetiva do Estado na concretização dos direitos fundamentais, os quais a opção liberal por si só não foi capaz de implementar.

De acordo com a crítica do professor Paulo Bonavides, a evolução do Estado liberal conduziu à superação de uma crise entre o poder absoluto do rei e o poder econômico dos feudos, para o surgimento da contradição entre o liberalismo e a democracia.

De acordo com Paulo Bonavides:

\begin{abstract}
Antes, o político (o poder do rei) tinha ascendência sobre o econômico (o feudo). Depois, dá-se o inverso: é o econômico (a burguesia, o industrialismo) que incialmente controla e dirige o político (a democracia), gerando uma das mais furiosas contradições do século XIX: a liberal-democracia ${ }^{47}$.
\end{abstract}

Se houve uma mudança no arquétipo do Estado, por certo que a configuração do Poder, a distribuição e forma de seu exercício sofreram influência direta enquanto representação deste mesmo Estado.

A primeira grande mudança nesta arquitetura estatal demonstrada nos parágrafos anteriores sente-se no crescimento da função executiva do Estado e na assunção de novas competências pelo órgão executivo ${ }^{48}$.

De acordo com Manoel Gonçalves Ferreira Filho em sua clássica obra, Do Processo Legislativo, dois fatores são fundamentais ao esvanecimento do poder legislativo e

${ }^{47}$ BONAVIDES, Paulo. Do Estado Liberal ao Estado Social. 9a. ed. São Paulo: Malheiros Editores, 2009. p. 55.

${ }^{48}$ Em sua obra A Democracia no limiar do século XXI, Manoel Gonçalves Ferreira Filho traz interessante análise, a qual passamos a colacionar: "Quando foram dados os primeiros passos do intervencionismo, foi o Executivo que assumiu a tarefa. Fê-lo não só porque a democratização o tornou cabeça da representação política, seja ele um Presidente eleito, ou um gabinete que exprima a maioria parlamentar, mas também porque somente ele o poderia fazer. Com efeito, a condução de uma política econômica reclama decisões prontas, sigilosas o mais das vezes, que nunca um Parlamento poderia ou conseguiria tomar. Lembre-se que esse se baseia no livre debate - até a exaustão, não raro - e isso permite a obstrução, ou os desvios de orientação indispensáveis à soma de apoios. Assumindo esta missão, o Executivo ganhou força junto ao povo, o eleitorado, porque a final seria ele quem satisfaria suas reivindicações. E, por outro lado, veio com isso a usurpar - primeiro de modo discreto, depois de modo ostensivo, hoje de modo patente - o poder de legislar”. (FERREIRA FILHO, Manoel Gonçalves. A democracia no liminar do século XXI. São Paulo: Saraiva, 2001. p. 122). 
crescimento do poder executivo, o alargamento do sufrágio e a intervenção do Estado no domínio econômico, a influência deste ente, Mercado, nos rumos e decisões do Estado.

\begin{abstract}
Em verdade, o sufrágio universal trouxe a divisão para o seio das assembleias. Deixaram estas de ser grupos primários, como eram enquanto só a burguesia participava intensamente da vida política, onde as discordâncias não iam além dos pormenores, para se tornarem o campo de batalha onde cosmovisões hostis e interesses de classes irredutíveis, ou aparentemente irredutíveis, se digladiavam ${ }^{49}$.
\end{abstract}

A formulação consagrada por Montesquieu serviu aos ideais de uma classe emergente que se tornara dominante, seu liberalismo construiu a arquitetura necessária à manutenção da classe burguesa como principal ator deste então novo contexto social, sendo que, o legislativo, até então, formado por uma pequena parcela de nobres, exprimia satisfatoriamente os anseios desta mesma classe.

Os séculos seguintes cuidaram de descortinar a crise do modelo liberal, e, com o acesso das massas ao exercício do poder político, ainda que por meio da mesma democracia representativa já concebida nas revoluções liberais, com a devida expansão de seus participantes, a supremacia deste poder legislativo diminui na medida em que não se mostra capaz de atender à demanda desta nova fatia ativa da sociedade ${ }^{50}$.

O segundo fator de transformação possui caráter econômico, segundo Manoel Gonçalves Ferreira Filho, "as questões econômicas que as assembleias passaram a ter de enfrentar, à medida que se desenvolvia o intervencionismo, dificilmente se ajustam ao processo de debate público, inerente aos Parlamentos" $" 51$.

O advento do chamado Estado-Providência ou Estado-Social traz uma mudança de foco, principalmente sob o aspecto da existência de uma crise de eficiência do Poder Legislativo, como exposto na análise acima, aliada à atuação mais célere do Poder Executivo, seja no

\footnotetext{
${ }^{49}$ FERREIRA FILHO, Manoel Gonçalves. Do processo legislativo. São Paulo: Saraiva, 2002. p. 120.

${ }^{50}$ Mais uma vez, a abordagem de Paulo Bonavides sobre o tema faz-se precisa, apontando uma inversão na balança social, a qual antes da Revolução Francesa causou a crise que destituiu o antigo regime, e no século XX, alterou a concepção liberal de Estado. Nas palavras de Bonavides: "Antes, o político (o poder do rei) tinha ascendência sobre o econômico (o feudo). Depois, dá-se o inverso: é o econômico (a burguesia, o industrialismo) que incialmente controla e dirige o político (a democracia), gerando uma das mais furiosas contradições do século XIX: a liberal-democracia.” (BONAVIDES, Paulo. Do Estado Liberal ao Estado Social. 9. ed. São Paulo: Malheiros Editores, 2009. p.55).

${ }^{51}$ FERREIRA FILHO, Manoel Gonçalves. Do processo legislativo. São Paulo: Saraiva, 2002. p. 122.
} 
campo de atuação legislativa seja na tomada de medidas administrativas destinadas a atender aos anseios desta parcela da população que, repisa-se, passa a ser mais ativa e de certa forma participante, e ainda, atendendo aos interesses econômicos de uma economia de Mercado complexa, a qual demanda decisões com a complexidade e velocidade não conhecidas ao tempo das formulações setecentistas.

De acordo com Clèmerson Merlin Cleve, "com o Estado Social foram alargadas as funções exercidas pelo poder público. O Executivo assume boa parte das novas atividades recentemente conquistadas pelo Estado",52, e, ainda segundo o autor, "nesse tipo de Estado, duas variáveis simultâneas manifestam-se. Em primeiro lugar, a função legislativa atua como jamais atuou. O número de leis aumenta consideravelmente. Por outro lado, o Estado age cada vez mais por meio de outros instrumentos que não a lei",53.

Rubens Beçak afirma que "o século XX demonstrou que em todos os Estados do mundo, qualquer que seja o regime, o Executivo 'furtou' do Legislativo sua tarefa institucional de origem, qual seja o legislar" ${ }^{\prime 5}$.

Os parlamentos, sobretudo no século XXI, passaram a dar sinais de uma crise, não somente de legitimidade, mas sobretudo de ineficiência, dando terreno ao Poder Executivo para que agisse em seu lugar.

Vale mais uma vez trazer a análise de Nelson Saldanha:

\footnotetext{
De qualquer maneira, mesmo nos Estados que em nossos dias correspondem a nações capitalistas (e, portanto, teoricamente liberais), tem sido bastante perceptível a crise dos parlamentos, com enormes dificuldades para a manutenção do princípio clássico da separação dos poderes ${ }^{55}$.
}

O fenômeno da hipertrofia do poder executivo com certeza é a primeira mudança drástica sentida na concepção clássica da divisão tripartite dos poderes do Estado.

\footnotetext{
${ }^{52}$ CLEVE, Clèmerson Merlin. Atividade Legislativa do Poder Executivo. 2. ed. São Paulo: RT, 2000. p. 51.

${ }^{53}$ Idem, ibidem. p. 51.

${ }^{54}$ BEÇAK, Rubens. A Hipertrofia do Executivo Brasileiro: o impacto da Constituição de 1988. São Paulo: Própria, 2007. p. 43.

${ }^{55}$ SALDANHA, Nelson. O Estado moderno e a separação de poderes. São Paulo: Saraiva, 1987. p. 103-4.
} 
Esta mudança vetorial implica de um lado um alargamento das funções do chefe do poder executivo, mormente ao adentrar de forma ativa o campo da legiferação, o que na experiência brasileira se expressa, sobretudo, na inúmera quantidade de medidas provisórias, e por outro lado, um enfraquecimento do poder legislativo, as funções vinculadas a cada um dos poderes na concepção dos pensadores das revoluções da modernidade deslocam-se de forma drástica para o campo dos outros poderes.

O aparelhamento da função executiva alterou fundamentalmente a métrica do exercício das funções estatais.

Se por um lado, esta foi a mais significativa, e a primeira grande mudança nos pesos desta balança de funções, posteriormente, estas mudanças também se sentiram no âmbito Poder Judiciário.

Diante de um quadro em que a função executiva passou a legislar de forma ativa e massiva, agindo sobretudo em coordenação com o Poder Legislativo, seja nos governos parlamentaristas, em que por sua natureza esta relação entre executivo e legislativo mostrase fundida, seja nos governos presidencialista, em que a articulação do governo dentro do parlamento faz-se necessária à realização de seus programas, do Poder Judiciário assume certamente posição destacada, em especial no controle da atividade destes órgãos com relação ao disposto na Constituição e na Lei, sua função de controle, e convalidação dos atos dos demais poderes torna-se fundamental.

Cabe aqui transcrever as palavras de Rubens Beçak, em seu artigo "O Tribunal Constitucional e sua Intervenção no Processo Político":

\footnotetext{
Com o desenvolvimento do controle de constitucionalidade, já no início do século XIX, com o famoso caso Marbury vs. Madison, vai o Poder Judiciário, no caso representado pela Suprema Corte americana, assumir papel de fiel da balança dos poderes. Realmente. Com o desenvolvimento do controle de constitucionalidade, o Poder Judiciário vai imbuir-se do papel - mesmo que potencial - de convalidador (ou não ) da vontade geral expressa na lei ${ }^{56}$.
}

O período do pós Segunda Grande Guerra influencia também, de forma concomitante ao Welfare State, uma nova mentalidade que passa a permear o constitucionalismo, em

\footnotetext{
${ }^{56}$ Congresso Nacional do CONPEDI, 17, 2008, Salvador, Anais, p. 2768.
} 
especial com reflexos no texto das Constituições na experiência ocidental, fator que de certa forma alimentou o desenvolvimento do Controle de Constitucionalidade e a expansão do Poder Judiciário.

O crescimento da doutrina dos Direitos Fundamentais alterou o conteúdo das Constituições, que passaram a consubstanciar-se no porto seguro contra os abusos e arbitrariedades do Poder.

Juntamente a esta mudança paradigmática dos textos constitucionais, o controle jurisdicional e a supremacia da Constituição passam a ser vistos como dois lados de uma mesma moeda, o que foi de grande importância no decorrer do século XX.

Conrado Hübner Mendes aponta, sob a influência da Lei Fundamental de Bonn, datada de 1949, que há uma mudança paradigmática do constitucionalismo, ao introduzir um rol de princípios abertos no texto constitucional, não passíveis de alteração por emenda constitucional, sobre os quais caberia ao Tribunal Constitucional Federal o controle ${ }^{57}$, bem como, uma imbricação entre o Controle Judicial de Constitucionalidade e a Supremacia da Constituição.

Cabe transcrever trecho da obra de Conrado Hübner Mendes:

\begin{abstract}
Controle jurisdicional e supremacia da Constituição (ou proteção dos direitos fundamentais) passaram a ser vistos como interdependentes, faces de uma mesma moeda. Essa foi a operação conceitual mais bem sucedida da teoria constitucional contemporânea. Em síntese, pode-se ordenar logicamente esse conhecido argumento nos seguintes passos: a catarse democrática não poderia colocar direitos fundamentais em risco; a rigidez constitucional é justificada como um anteparo que arrefece os ânimos do legislador e garante a estabilidade e a justiça substantiva da própria democracia; assim, tais direitos ficam imunes ao capricho da maioria. O controle jurisdicional de constitucionalidade poria em prática essa aspiração ${ }^{58}$.
\end{abstract}

Este quadro, que será melhor explorado nos capítulos seguintes, certamente trouxe alterações ao equilíbrio clássico da balança de poderes de Montesquieu.

\footnotetext{
${ }^{57}$ MENDES, Conrado Hübner. Controle de Constitucionalidade e Democracia. Rio de Janeiro: Elsevier, 2008. p. 8.

${ }^{58}$ Idem, ibidem. p. 13
} 
Aliados a este novo posicionamento do Poder Judiciário, outros fatores são fundamentais ao seu desenvolvimento, dentre eles o aparelhamento dos sistemas de controle de constitucionalidade.

Este desenvolver dos mecanismos alçados ao Poder Judiciário no âmbito do controle de constitucionalidade têm propiciado em grande parte esta mudança na importância e posicionamento da função jurisdicional na balança dos poderes

A arquitetura de uma divisão de poderes estanque idealizada por Montesquieu e seus contemporâneos ocupa na atualidade importância menor em face das transformações materiais da sociedade e do Estado.

Uma das críticas mais contumazes a este modelo pode ser encontrada na obra de Karl Loewenstein.

O constitucionalista alemão traça apurada análise sobre a superação do modelo setecentista, construindo uma nova separação de poderes, distante da formulada pelas revoluções liberais ${ }^{59}$.

Loewenstein propõe uma nova divisão tripartite adequada ao século $\mathrm{XX}$, sob a ótica de uma sociedade pluralista de massas, a qual consiste em, "la decisión política conformadora o fundamental (policy determination); la ejecución de la decisión (policy execution) y el control político (policy control) ${ }^{" 60}$.

Dentro da nova concepção da divisão de poder de Karl Loewenstein, a chamada decisão política fundamental consiste na formulação, revestida sob a forma de lei, seja ela de iniciativa pelo Legislativo, seja de iniciativa do Governo, das opções fundamentais dentro de uma sociedade pluralista.

\footnotetext{
${ }^{59}$ A crítica do constitucionalista alemão é precisa, sendo que em suas palavras: "Es necesario tener bien claro que el principio de la necesaria separación de las funciones estatales según sus diversos elementos substanciales y su distribución entre diferentes detentadores, ni es esencial para el ejercicio del poder político, ni representa una verdad evidente y válida para todo tiempo. El descubrimiento o invenciónde la teoría de la separación de funciones estuvo determinado por el tiempo y las circunstancias como una protesta ideológica des liberalismo político contra el absolutismo monolítico de la monarquia en el siglo XVII y XVIII." (LOEWENSTEIN, Karl. Teoria de la Constitucion. Alfredo Gallego Anabitarte (Trad.). Barcelona: Ediciones Ariel, 1965. p. 62)

${ }^{60}$ Idem, ibidem. p. 62.
} 
Nas palavras do constitucionalista alemão:

\begin{abstract}
La determinación de la decisión política fundamental, o toma de la decisión politica, consiste en la elección de una, entre varias posibilidades políticas fundamentales, deben considerarse aquellas resoluciones de la sociedad que son decisivas y determinantes, en el presente y frecuentemente en el futuro, para la conformación de dicha comunidad. Conciernen tanto a asuntos extranjeros como internos, materialmente pueden ser de naturaliza politica, socioeconómica $y$ hasta moral, por ejemplo, cuando se refieren a cuestiones religiosas ${ }^{61}$.
\end{abstract}

Tomadas as decisões fundamentais no seio social, sua execução encontrar-se-ia dividida entre os três órgãos do poder concebidos na divisão clássica, embora a execução da decisão se faça em diferentes graus e formas ${ }^{62}$.

Neste desenho traçado, em que se vislumbra uma sociedade repleta de interesses e de participação mais intensa dos atores sociais, o que se mostrava como um fato já percebido por autores do início do século XX, e claramente, em intensidade exponencial na sociedade contemporânea, em que diversas decisões no âmbito da política, da moral, da religião de das demais questões fundamentais aos desenvolvimento social são tomadas e positivadas, seja por lei fruto do processo legislativo clássico, seja pela legiferação governamental, e postas em execução por todos os órgãos do Poder, assume papel fundamental a terceira função estatal exposta por Loewenstein, o controle político.

A função de controle político (terceiro poder ou função), pelo qual deve haver mecanismos legados aos três detentores do poder, acrescidos de um novo detentor do poder, o eleitorado, de controle sobre os atos e exercício do poder por cada um de seus titulares.

É o fortalecimento da já consagrada fórmula do sistema de freios e contrapesos. Segundo o constitucionalista alemão, este seria o núcleo da nova divisão de funções.

${ }^{61}$ LOEWENSTEIN, Karl. Teoria de la Constitucion. Alfredo Gallego Anabitarte (Trad.). Barcelona: Ediciones Ariel, 1965. p. 63.

${ }^{62}$ Loewenstein explicita a forma de atuação destes diversos órgãos na execução das decisões políticas fundamentais da seguinte forma: "El parlamento participa al formular a través de la legislación la decisión política tomada, y al establecer para la comunidad las reglas puramente técnico-utilitarias. El gobierno participará en esta función a través de la administración por medio de sus autoridades y funcionarios y, finalmente, los tribunales lo harán al resolver los casos concretos de conflictos de intereses, así como al controlar ampliamente la legalidad de la administración, es decir, si la actividad administrative se encuentra de acuerdo con la ley." (LOEWENSTEIN, Karl. Teoria de la Constitucion. Alfredo Gallego Anabitarte (Trad.). Barcelona: Ediciones Ariel, 1965. p. 68) 
Este controle dar-se-ia de duas formas: primeiramente pela distribuição do poder, quando a realização dos atos por parte do Estado depende da coordenação de vontade entre detentores de funções distintas, distribuídas fundamentalmente entre o Governo, o Legislativo, o Judiciário e o Povo, e, em segundo lugar, pela atuação autônoma de cada um dos entes do poder, como por exemplo, a atuação do Judiciário no âmbito do controle de constitucionalidade, a participação do eleitorado na realização de plebiscitos e referendos, dentre outras formas autônomas de controle.

\begin{abstract}
En el Estado constitucional, la función de control es doble: por una parte consiste en el hecho de que un acto estatal sólo tine lugar cuando los diversos detentadores del poder están dispuestos a una común actuación. Aquí se da el control por la distribución del poder. Pero el control puede también consistir en que un detentador del poder impida la realización de un acto estatal, o que ponga en juego su existencia como ocorre en el caso de un voto de no confianza del parlamento al gobierno, o la disolución del parlamento por el gobierno. Aqui se da el control autónomo del poder ${ }^{63}$.
\end{abstract}

Dentro de um quadro em que o exercício das funções de execução das decisões políticas conformadoras, usando a terminologia adotada, distribui-se entre o Executivo, o Legislativo e o Judiciário, o controle recíproco destes órgãos é essencial.

A leitura do autor sobre o constitucionalismo, sob a ótica do século $\mathrm{XX}$, reside fundamentalmente no aumento da participação do povo como um detentor do poder, e, em um governo baseado não somente sob a égide de um Estado de Direito, mas sim um governo responsável ${ }^{64}$.

Confluindo com a crítica traçada por Karl Loewenstein, o constitucionalista português Nuno Piçarra, em obra de referência sobre o tema, A Separação dos Poderes como Doutrina e Princípio Constitucional, aponta a superação do modelo no que concerne à

\footnotetext{
${ }^{63}$ LOEWENSTEIN, Karl. Teoria de la Constitucion. Alfredo Gallego Anabitarte (Trad.). Barcelona: Ediciones Ariel, 1965. p. 70.

${ }^{64}$ Sobre o conceito de governo responsável, cabe transcrever trecho de sua obra, onde podemos verificar uma ligação estreita deste conceito com a figura do controle, central nesta nova métrica da divisão das funções estatais. "Un gobierno se puede considerar como responsable cuando el ejercicio del poder político está distribuido y controlado entre diversos detentadores del poder. Las técnicas del controle $n$ su totalidade están ancladas en la constitución. La supremacia de la constitución es el remate de un sistema integral de controles políticos." (LOEWENSTEIN, Karl. Teoria de la Constitucion. Alfredo Gallego Anabitarte (Trad.). Barcelona: Ediciones Ariel, 1965. p. 71)
} 
identificação de cada uma das funções com as forças político-sociais vigentes, subsistindo apenas em uma acepção orgânico-funcional ou normativa ${ }^{65}$.

A ascenção do princípio democrático como fonte de legitimação do Poder do Estado, fenômeno ligado ao enfraquecimento das oligarquias sociais e políticas tradicionais, e ao crescimento e diversificação dos atores sociais, com sua maior participação no jogo político, seja por meio de corporações, partidos políticos, grupo de interesses, desloca para fora da estrutura estatal a titularidade do Poder Político ${ }^{66}$.

O princípio passa a servir como médium de realização da vontade democrática, mostrandose na atualidade não mais como uma verdade universal e conformadora de caráter a priori, mas sim como elemento de caráter normativo organizacional do Estado, que se afere na concretude das ordens constitucionais, na realização da vontade política emanada sob a égide de uma sociedade democrática.

\begin{abstract}
O princípio da separação dos poderes deixa de se contrapor ao princípio democrático para legitimar poderes autónomos em relação a este, e passa a desenvolver a sua acção apenas no quadro do princípio democrático, como princípio de organização do poder político-estadual, todo ele democraticamente legitimado. O princípio da separação dos poderes deixa, pois, de ser chamado a balancear o princípio da legitimidade democrática e outros princípios de legitimidade, para se subordinar exclusivamente ao primeiro ${ }^{67}$.
\end{abstract}

O exposto pelo professor da Faculdade de Direito de Lisboa conflui com o pensamento de Karl Loewenstein na medida em que ambos os autores identificam na multiplicidade de interesses multifacetários da sociedade pluralista do século XX, e no incremento de sua participação no processo decisório, fator fundamental de mudança no arquétipo estatal idealizado nas revoluções setecentistas.

\footnotetext{
${ }^{65}$ PIÇARRA, Nuno. A Separação dos Poderes como Doutrina e Princípio Constitucional. Coimbra: Coimbra Editora, 1989. p. 245.

${ }^{66}$ Nas palavras do constitucionalista luso: "É certo que o surgimento de grupos sociais politicamente relevantes determinou uma deslocação do poder político, antes pretendido monopólio do Estado, para áreas extra-estaduais ou para-estaduais. No entanto, uma harmonização, tal como Montesquieu tinha previsto, entre uma balança dos poderes dentro dos e/ou entre vários órgãos estaduais e a balança constituída pelo pluralismo dos titulares oligárquicos do poder político-social, através de sua participação, enquanto tais, naqueles órgãos não é hoje possível em nome do princípio democrático que apenas permite considerar directa e imediatamente o povo como substrato dos órgãos constitucionais. O que quer dizer que, no Estado de Direito contemporâneo, o princípio constitucional da separação dos poderes se dissociou, e deve ficar dissociado, definitivamente, da temática da constituição mista." (PIÇARRA, Nuno. A Separação dos Poderes como Doutrina e Princípio Constitucional. Coimbra: Coimbra Editora, 1989. p. 233)

${ }^{67}$ Idem, ibidem. p. 235.
} 
Este novo quadro impacta no exercício das funções estatais clássicas, uma vez que a elaboração da decisão política fundamental ou conformadora, utilizando aqui terminologia empregada por Loewenstein, decorre da atuação conjunta dos que detêm o poder, sobretudo das funções executiva e legislativa, em grande parte com limites de atuação difusos, sobretudo quando observado o modelo parlamentar europeu e o crescimento de funções e participação do Executivo no âmbito das decisões legislativas, seja por coordenação das maiorias partidárias, seja por sua atuação direta, como no caso brasileiro, a edição de instrumentos legislativos como a medida provisória.

A conformação desta decisão política fundamental resulta da coordenação tanto dos detentores invisíveis do poder, novamente tomando emprestados os termos do constitucionalista alemão, como dos grupos componentes do neocorporativismo de Nuno Piçarra, com a atuação orgânico-funcional dos Poderes estatais.

Não somente neste ponto, o qual descortina a adequação de uma nova realidade social, pluralista, democrática, em comparação a identificação entre os órgãos e funções e o arranjo político-social vigente, que Montesquieu e os pensadores das evoluções liberais construíram como base de sua divisão e atribuição de funções aos órgãos do Poder, mas claramente em relação ao alargamento das atribuições de cada uma destas funções, faz-se sentir uma mudança central na teoria clássica.

A incorporação de outras funções materiais pelos órgãos do poder passou a trazer uma adequação meramente formal que ligaria determinado órgão aos atos por ele praticados, embora materialmente tenham incorporado funções atípicas dos demais órgãos.

Outro importante fator de mudança percebido por ambos os constitucionalistas em exame reside no incremento da função de controle, e neste ponto, voltamos nossa observação principalmente ao poder Judiciário.

Segundo Nuno Piçarra, no Estado de Direito Contemporâneo os mecanismos de controle exercidos pelo Poder Judiciário têm assumido papel fundamental dentro na nova ótica do princípio da separação dos poderes ${ }^{68}$.

\footnotetext{
${ }^{68}$ Nas palavras do autor: "Tem-se mesmo considerado que os controlos de natureza jurídica efectuados por um poder judicial independente, tendem a superar em importância, para efeitos da moderação e limitação do
} 
O caráter de independência alçançado pelo Poder Judiciário neste iter evolutivo ocorrido desde o advento do arranjo politico constitucional das revoluções liberais certamente o colocou como ente fundamental na atividade de controle dos demais poderes, sobretudo quando observamos uma confluência na atuação dos Poderes Executivo e Legislativo, os quais não mais se encontram realmente separados no plano material, agindo em constante coalisão, ambos para a realização de um mesmo fim, expresso sobretudo sob a roupagem da lei, fruto da atuação destes Poderes.

Esta atribuição de controle deriva da ideia de um sistema de freios e contrapesos, tendo o Poder Judiciário papel fundamental nesta função, cerne do princípio da separação dos poderes.

A visão expressada por Piçarra parte da premissa de que, no Estado Contemporâneo, a lei passa a ser o instrumento conformador e de expressão da vontade política, vontade política esta decorrente de um processo de diálogo entre os Poderes Executivo e Legislativo, bem como, dos elementos exógenos do Poder, detentores de fato de sua titularidade.

Dentro deste contexto, a figura de um Poder autônomo e afastado deste processo surge como o principal ponto de contenção a esta vontade e como meio de preservação dos valores erigidos no processo político.

\footnotetext{
Porque a natureza da lei é política mas também jurídica, porque a sua componente política pode sobrepor-se à sua componente jurídica e pode postergar os valores jurídico-constitucionais fundamentais, ela convoca ipso facto no Estado de Direito - em que, pela disposição das coisas o poder limita o poder - um freio e um contrapeso, ou seja, um poder destinado a garantir na lei esses valores. Ora, o poder mais adequado e idóneo para isso é o poder judicial, cuja função se caracteriza e deve caracterizar-se justamente, pela sua natureza exclusivamente jurídica, despida de qualquer compromisso ou intenção política conjuntural, visando apenas a salvaguarda e a actualização daqueles valores ${ }^{69}$.
}

poder estadual, os controlos de natureza política entre os órgãos constitucionais de direção política (parlamento e governo), os quais estão unificados pelo(s) partidos(s) maioritários(s). O sistema de controlos jurídicos constituiria o núcleo essencial do princípio da separação dos poderes no Estado de Direito contemporâneo". (PIÇARRA, Nuno. A Separação dos Poderes como Doutrina e Princípio Constitucional. Coimbra: Coimbra Editora, 1989. p. 259)

${ }^{69}$ Idem, ibidem. p. 260. 
A análise das balizadas críticas e observações colacionadas nos parágrafos anteriores nos permite observar fundamentalmente uma alteração no equilíbrio e distribuição de funções, as quais provavelmente mantêm-se intactas e fiéis somente em sua nomenclatura, não havendo mais a absoluta identidade hermética entre a natureza da atividade desenvolvida e cada órgão específico, tal como formulada pelos pensadores das revoluções liberais.

O valor fundamental do princípio no Estado contemporâneo reside no exercício de controles recíprocos entre os Poderes, fator que se demonstra de maior importância com o advento de uma sociedade complexa e multifacetária, na qual exponencialmente crescem interesses de grupos diversos e por vezes antagônicos, exercendo forte pressão sobre os decision makers.

Deve-se observar que, embora o campo de atuação legiferante tenha se deslocado em grande parte ao Poder Executivo, pelos diversos fatores citados anteriormente, é certo que a lei continua a ser a expressão fundamental e necessária desta vontade.

A concepção herdada das revoluções liberais, da lei como expressão de soberania, da legislação como médium entre a vontade social e os limites da atuação do Estado e da sociedade, reforça-se nos séculos seguintes, sobretudo com o advento do positivismo jurídico, o qual colocou a figura da lei como fonte fundamental e necessária de direitos e garantias.

Dentro de um contexto no qual a pluralidade de interesses e o aumento da participação mostram-se como a grande tônica desta sociedade, as decisões políticas fundamentais, usando aqui a terminologia empregada por Loewenstein, expressas sob a forma de lei, assumindo aqui sentido amplo, abrangendo tanto normas de caráter constitucional quanto legais ou infralegais, mostram-se cada vez mais difusas, carregadas de conteúdos morais e opções legislativas por vezes colidentes.

A implicação destes fatores, da legislação como expressão necessária das decisões políticas fundamentais, e, da diversidade e pluralismo dos interesses e questões expressas nesta legislação, certamente colocou sobretudo a Função Jurisdicional em um terreno no qual seus limites passaram a ser objeto de análise e debate no meio acadêmico e dos operadores do Direito. 
A função que outrora nada mais realizava a não ser pronunciar os comandos da lei, em um processo exegético autômato, agora depara-se com parâmetros de controle cada vez mais eivados de conteúdo axiológico e semântico amplos.

Dentro deste contexto, torna-se tarefa árdua limitar a fronteira entre o juris dicere e seus limites contemporâneos, e aquilo que parte da doutrina e da práxis do Direito enxerga como um desvio de finalidade da atividade Judicial, colocando sua atuação como verdadeiro decison maker.

Questões complexas, as quais segundo considerável parte da crítica deveriam ser objeto do debate legislativo, ou mesmo no seio da articulação entre os Poderes Executivo e Legislativo, já que é assente na atualidade que a divisão destes órgãos deu lugar a um campo de coordenação e realização da atividade governamental, têm sido postas em debate perante o Poder Judiciário, resultando em decisões, sobretudo no âmbito do controle de constitucionalidade, que não raro tem feito às vezes de decisões políticas fundamentais, novamente tomando emprestada terminologia de Loewenstein.

O princípio da separação dos Poderes ainda se mostra caro e de extrema importância ao desenvolvimento das democracias no século XXI, contudo, é certo que não podemos fechar os olhos à sua nova roupagem, dando-lhe o valor necessário sem que fiquemos presos a conceitos erigidos sob uma sociedade que não mais espelha a complexa realidade político-social contemporânea.

O núcleo essencial das funções estatais, em que pesem os influxos dos tempos atuais, parece manter-se vigente, sob pena de um desmoronamento de pilares fundamentais do Estado Moderno, o qual, mesmo que procedente parte das críticas hodiernas, não pareça viver em uma ruptura completa com seus primórdios históricos, mas sim em evolução, sendo a ele agregadas novos matizes e contornos.

Jorge Miranda, em seu Manual de Direito Constitucional, afirma: 
O princípio da separação de poderes vai, pois, permanecer como princípio de organização óptima das funções estatais, de estrutura orgânica funcionalmente adequada, de legitimação para a decisão e de responsabilidade pela decisão. Daí uma dimensão positiva, a par de uma dimensão negativa, de controlo e limitação de poder. E, consequentemente, reconhece-se a necessidade de um núcleo essencial de competência de cada órgão, apurado a partir da adequação da sua estrutura ao tipo ou à natureza de competência de que se trata ${ }^{70}$.

Passaremos a traçar de forma minuciosa o desenvolvimento da função judicial sob o prisma de sua atuação contemporânea, iniciando com sua evolução desde o advento da República, o desenvolvimento de nosso sistema judicial de controle de constitucionalidade, terminando sob o surgimento do chamado ativismo judicial e suas implicações na Democracia.

\footnotetext{
${ }^{70}$ MIRANDA, Jorge. Manual de Direito Constitucional. Tomo II. Constituição. 5a . ed. Coimbra: Coimbra Editora, 2005. p. 385.
} 


\section{Poder Judiciário e a República Brasileira}

Os apontamentos apresentados no capítulo anterior nos permitirão construir nos próximos parágrafos um quadro de comparação entre aquilo que as revoluções liberais chamaram de Poder Judiciário e o novo Poder que se descortinou no decorrer do século XX, sobretudo na experiência brasileira.

Nesta análise, a evolução do Poder Judiciário pode ser traçada em dois momentos distintos.

No primeiro deles, que se inicia no final do século XIX até os momentos antecessores à Constituição de 1988, trata-se do período de sua afirmação com funções e garantias bem delimitadas, cada vez mais atuante na resolução de conflitos, ocupando a figura de garantidor da ordem jurídica vigente.

O segundo momento, e aqui reside a especial atenção deste trabalho, consiste em uma evolução que parte da doutrina enxerga para além da mera função jurisdicional de médium da aplicação do sistema normativo aos casos concretos, para uma atuação considerada por muitos exacerbada e deletéria para a própria democracia, a qual, adotando terminologia atual, passaremos a chamar de ativista.

Este avanço substancial na atuação do Poder Judiciário ocorre em especial pelo incremento do sistema judicial de controle de constitucionalidade no Brasil.

Como ponto de partida, são fundamentais as lições constantes nas obras de Pedro Lessa, em Do Poder Judiciário, datada de 1915, do jurisconsulto João Mendes de Almeida Junior, em Direito Judiciário Brasileiro, com sua primeira edição em 1918, dentre outros autores que passamos a expor.

A definição de Poder Judiciário segundo João Mendes de Almeida Júnior se assemelha em grande parte a concepção liberal setecentista.

O PODER JUDICIÁRIO distingue-se do Poder Legislativo, porque pressupõe a existência da lei, apara aplica-la aos casos ocorrentes; o PODER JUDICIÁRIO não faz leis, dita as leis já existentes e as aplica a um caso hic et nunc. Distinguese do Poder Executivo, por isso que, conquanto, em um sentido amplo, o 
PODER JUDICIÁRIO não deixe de ser um poder executivo-administrativo, distingue-se, entretanto, do restrito poder administrativo sob os seguintes pontos de vista: 1) porque o poder restritamente administrativo, tendo por objeto a ação social e direta do Estado, as suas relações com os indivíduos não podem, a não ser por uma desclassificação, atingir imediatamente senão o interêsse[sic] geral e só mediante direitos do indivíduo; 2) porque o poder administrativo tem ação contínua e incessante inciativa em relação às necessidades e interesses sociais, ao passo que o Poder Judiciário, em regra, não tem iniciativa, por isso que sua ação é subordinada à provocação do indivíduo que reclama a reintegração e tutela do seu direito violado, desconhecido ou ameaçado. O Poder Judiciário, em regra, só exerce a sua função, isto é, a JURISDIÇÃO, mediante provocação, ao passo que as funções dos outros podêres[sic] podem ser espontâneas ou provocadas ${ }^{71}$.

Prosseguindo na obra de João Mendes de Almeida Júnior:

A JURISDIÇÃO, função de declarar o direito aplicável aos fatos, é a causa final específica da atividade do Poder Judiciário. Assim como é função própria e exclusiva do poder Legislativo a de fazer leis (jus dare, como diziam os Romanos), - a do Poder Executivo executar as leis (jus executare), - é função própria e exclusiva do Poder judiciário dizer a lei existente aplicável a um fato ocorrente nas relações entre indivíduos (jus dicere) $)^{72}$.

Observando o conceito de jurisdição dado por João Mendes Junior, nota-se uma visão restrita e próxima às construções liberais sobre a função judicial, "jurisdição consiste somente na função legítima que tem o juiz de conhecer da causa e proferir sua sentença"73.

Em obra de referência fundamental, Pedro Lessa abre o capítulo primeiro de seu Do Poder Judiciário com uma definição do que seria este poder e de quais seus limites, os quais denomina de caracteres distintivos.

$\S 1 \mathrm{O}$ poder judiciario é o que tem por missão applicar contenciosamente a lei a casos particulares.

A tres se reduzem os principaes caracteres distinctivos do poder judiciario : $1^{\circ}$ as suas funcções são as de um arbitro ; para que possa desempenha-las, importa que surja um pleito, uma contenda; 2 só se pronuncia acerca de casos particulares, e não em abstracto sobre normas, ou preceitos jurídicos, e ainda menos sobre principios; 3 não tem iniciativa, agindo - quando provocado, o que é mais uma consequência da necessidade de uma contestação para poder funccionar. ${ }^{74}$

\footnotetext{
${ }^{71}$ ALMEIDA JÚNIOR, João Mendes de. Direito Judiciário Brasileiro. 5a . ed. Rio de Janeiro: Livraria Freitas Bastos S/A, 1960. p. 40.

${ }^{72}$ Idem, ibidem. p. 40.

${ }^{73}$ Idem, ibidem. p. 41.

${ }^{74}$ LESSA, Pedro. Do Poder Judiciario. Rio de Janeiro: Livraria Francisco Alves, 1915. p. 1.
} 
A leitura dos chamados caracteres distintivos, acima colacionados, permite observar que ao Poder Judiciário era vedado conhecer sobre casos em abstrato, e "ainda menos sobre princípios", o que contrasta fundamentalmente com o atuação de nossos tribunais, sobretudo do Supremo Tribunal Federal, hoje tradutor dos inúmeros princípios insculpidos na Constituição Federal, principal ator da leitura destes axiomas, com as mais diversas implicações para questões fundamentais do debate político e social.

O professor Herculano de Freitas, em umas das primeira obras brasileiras dedicadas ao Direito Constitucional do início do século XX parecia vislumbrar, ainda que sob a égide de um sistema de divisão do Poder muito similar aos primórdios clássicos, a evolução da Justiça, com seu alargamento e maior intervenção do Estado, o que se percebeu no alargamento das funções do Poder Executivo, e por derradeiro, num implemento das funções do Poder Judiciário.

Leciona Herculano de Freitas, no capítulo de sua obra denominado "Nova Ideia de Justiça":

\begin{abstract}
As modificações nas organizações políticas decorrentes da guerra e das consequências de revoluções sociais das massas proletárias, ensinam que se caminha para um regime de mais ação do Estado, de menos faculdades individuais, e, portanto, para uma dilatação do Direito Público com sacrifício do Direito Privado. A concepção individualista cede terreno à doutrina socialista. Tudo parece indicar que a humanidade caminha para um governo em proveito das massas, por intermédio do Estado, e, portanto, para uma transformação até de fenômenos econômicos em regras jurídicas, sob uma nova compreensão da idéia[sic] de Justiça - não já a "constans et perpetua voluntas jus suum cuique tribuendi", mas sim a "vontade constante de dar a cada um o que lhe fôr indispensável para viver e progredir", fundado assim o Direito no princípio da solidariedade social ${ }^{75}$.
\end{abstract}

Essa "Nova Ideia de Justiça" concretizou-se no decorrer do século, não como um Estado socialista planificador, mas sob o viés das sociais democracias e Estados-providência, demandando um alargamento da Justiça, seja sob o enfoque material do termo, ou do funcional, implicando a expansão da chamada Jurisdição.

Ainda na obra do professor da Faculdade de Direito do largo de São Francisco, embora contenha uma visão mais alargada da função do Estado, firma-se o Poder Judiciário como o médium entre a normatividade e a sociedade, aplicando o direito aos litígios concretos,

\footnotetext{
${ }^{75}$ FREITAS, Herculano de. Direito Constitucional. São Paulo: (s.e), 1923. p. 5-6.
} 
"Poder Judiciário, quer dizer o órgão do governo incumbido de exercer a função jurisdicional, incumbido de julgar e proferir sentenças, de dizer o direito" ${ }^{\text {76 }}$.

Em meados da década de 60, destacam-se as obras de Antonio de Sampaio Doria, o qual trouxe observações importantes sobre a atuação do Poder Judiciário, que podem ser contrastadas com o quadro atual de nossa Corte Suprema, e, Aliomar Baleeiro, na célebre obra "Supremo Tribunal Federal, Esse outro desconhecido".

O professor Sampaio Doria traz uma abordagem em que afirma, na mesma esteira das obras acima mencionadas, balizas claras à atuação do órgão judicante, sem contudo negar a necessidade de sua atuação como órgão de controle da atividade legislativa e executiva que transbordassem os limites do texto constitucional.

\footnotetext{
Não cabe ao poder judiciário nem inovar princípios, nem legislar normas práticas. Mas aplicar a lei, quando invocado, na solução de factos em litígio, ou cujo direito se precise legalizar, ou fixar. Por outras palavras, consiste a função legítima do poder judiciário em dizer a cada um o que é seu, nos casos concretos, para cujo exame seja chamado ${ }^{77}$.
}

Em capítulo de sua obra Direito Constitucional, denominado "Atritos com o Poder Judiciário", Sampaio Dória reforça a necessidade da atuação judicial, ainda que em contenção à atividade do governo e do legislador ${ }^{78}$.

\footnotetext{
${ }^{76}$ FREITAS, Herculano de. Direito Constitucional. São Paulo: (s.e), 1923. p. 397.

${ }^{77}$ DORIA, Antonio de Sampaio. Direito Constitucional. São Paulo: Max Limonad, 1958. p. 617. v. 1.

${ }^{78}$ Cabe a necessária transcrição em rodapé dos excertos da referida obra. Sobre a tensão possível entre os poderes, afirma Sampaio Doria: "Tais atritos só podem ser de natureza judiciária. São excluídas as questões estritamente políticas, isto é, as que se decidem, não pelo critério da lei, mas pelas conveniências actuais. Um juiz não pode, por exemplo, revogar uma lei, ou nomear um embaixador, decretar o estado de sítio, ou dissolver o parlamento. A missão do juiz é resolver uma questão de direito por provocação da parte, ou, mesmo, por exceção da lei, "ex-officio". Só no exercício desta missão é que poderiam surgir atritos. Atritos com o governo, ou atritos com o parlamento." (Idem, ibidem. p. 293). Ao abordar um possível conflito com o Legislativo, a análise, à luz do contexto institucional da época, parecia ainda não vislumbrar os desdobramentos ocorridos nas décadas seguintes sobre o incremento da atividade judicial em sede de controle de constitucionalidade e seus desdobramentos. Aduz o ilustre constitucionalista: "E se o atrito fôr[sic] com o poder legislativo? Elaborou o congresso uma lei, que se acoima de inconstitucional. Recorrem os prejudicados aos tribunais, para que resolvam a questão de direito suscitada. Colidindo com a lei constitucional a lei ordinária, não pode o tribunal eximir-se do dever de aplicar a lei constitucional, que a ordinária não derroga." (Idem, ibidem. p. 294). Ainda em resposta como solução a esta tensão: "Quer-se, porém, como é prudente, evitar semelhante conflito? É facílimo. Não saia o legislador da competência que tenha. Não tem competência para revogar, em elaboração comum, preceito constitucional. E se o tenta, exorbita." (Idem, ibidem. p. 295).
} 
À época, o debate no contexto nacional mostrava-se de certa forma incipiente, por certo pela postura ainda acanhada de nossas Cortes Superiores em matéria de controle de constitucionalidade, e sobretudo, ao nosso ver, por estar por vir a virada paradigmática ocorrida com o advento da Constituição de 1988, impactando nas características das normas constitucionais, ampliada substancialmente por princípios e conteúdos morais abertos erigidos a bloco de constitucionalidade.

Mesmo diante deste contexto ainda contido na atuação de nosso Supremo Tribunal Federal, as lições de Sampaio Doria mostram-se atuais e importantes para o exercício crítico sobre o tema.

Aliomar Baleeiro, em precisa análise, vislumbrava já em meados dos anos 60 um futuro de proeminência do Supremo Tribunal Federal, e de seu avanço substancial em questões outrora distantes do debate judiciário.

\begin{abstract}
Cúpula de todos êles, o Supremo carrega por precípua missão a de fazer prevalecer a filosofia política da Constituição Federal sôbre todos os desvios em que Congresso e o presidente da República, Estados, Municípios e particulares se tresmalhem, quer por leis sancionadas ou promulgadas, quer pela execução delas ou pelos atos naquela área indefinida do discricionarismo facultado, dentro de certos limites, a ambos aquêles Podêres. O traçado dêsses limites, quer quanto ao legislador quer quanto ao executor, nunca foi, não é, nem será nunca uma linha firme, clara e inconfundível. Há uma terra de ninguém desta faixa fronteiriça. Teoricamente, essas linhas jazem na Constituição. Mas como lei é obra de expressão do pensamento, ela padece de lacunas, antinomias e obscuridades, como os de qualquer outro país em qualquer época. $\mathrm{E}$ a ação do tempo, envelhecendo dispositivos ou desafiando o alcance de outros, senão o próprio silencia do texto, engendra os problemas que o Supremo Tribunal Federal ha de enfrentar pelo futuro afora, às vêzes como freio dos avanços temerários, outras vêzes como acelerador das aspirações agudas e das reformas latentes $^{79}$.
\end{abstract}

O perfil do Poder Judiciário do início do século por certo se mostrava delineado, com grau de importância reconhecido, mormente em seu aspecto de mecanismo de freio e contrapeso aos demais poderes, contudo, como exposto no início do presente capítulo, claramente não havia, ao menos na experiência nacional, dado o passo para adentrar na senda das questões tormentosas que hoje coloca sua atuação sob duras críticas por parte da doutrina.

\footnotetext{
${ }^{79}$ BALEEIRO, Aliomar. Supremo Tribunal Federal, esse outro desconhecido. Rio de Janeiro: Forense, 1968. p. 103.
} 
Ao analisarmos nosso Supremo Tribunal Federal, sob a égide da Constituição de 1891, sua atuação mostrava-se muito distante de suas diversas atribuições atuais, mormente se analisadas sob o enfoque do vasto aparato utilizado no controle abstrato de normas, no sopesamento e aplicação de princípios, questão de certa forma recente na doutrina e prática nacionais que trouxe grande expansão e alteração dos limites da função jurisdicional.

Ressalvada sua atuação em sede de competência originária, elencada no inciso I e alíneas do art. 59 da referida Constituição, sua atuação maior resumia-se ao julgamento em grau de recurso das questões decididas pelos Juízes e Tribunais Federais, o que segundo Pedro Lessa, a época, já se demonstrava fator preocupante por instituir nosso Supremo como uma terceira instância para as questões até então de índole federal ${ }^{80}$.

Ao tempo da Constituição da República, de 1891, o avanço fundamental de nosso Poder Judiciário ocorreu pelo fim de sua subordinação ao Poder Monárquico, a criação de uma Justiça Estadual e uma Federal, a criação de um Supremo Tribunal Federal sediado na capital da República, garantias como a vitaliciedade e irredutibilidade de vencimento aos seus membros, delineamentos que deram as bases à solidificação deste Poder.

Verifica-se que a doutrina nacional de meados do século XX passou a ter claro o papel fundamental do Poder Judiciário, sem contudo desbordar dos limites clássicos postos pelos pais da doutrina da separação de poderes, ainda que com análises que já vislumbravam um norte de expansão desta função, embora não com a magnitude a que esta se alça na atualidade.

Ao mesmo tempo em que paulatinamente a função judicial passou a ser vista como garantia da higidez da constituição, de importante contrapeso ao exercício arbitrário do poder, inclusive com a necessária intervenção no âmbito das funções legislativa e executiva que transbordassem seus poderes, e isto fica patente na lição de Sampaio Dória, era também certa a necessidade de preservação desta função nos exatos termos da jurisdição clássica, fiel aos parâmetros da lei, reservando ao campo do governo as decisões sobre matéria política, sem adentrar no campo reservado ao mister da função legislativa, dentro de um primado representativo de democracia, do qual o fruto decorre do exercício

\footnotetext{
${ }^{80}$ LESSA, Pedro. Do Poder Judiciario. Rio de Janeiro: Livraria Francisco Alves, 1915. p. 23.
} 
da atividade legislativa na eleição das pautas e diretrizes que espelham, ainda que formalmente, a vontade dos detentores do sufrágio.

Se estes eram os delineamentos gerais do Poder Judiciário brasileiro, sob os olhos da abalizada doutrina mencionada, cabe, ainda que de forma breve, um olhar sobre a evolução deste Poder, sob o aspecto de sua atuação como ente titular do controle judicial de constitucionalidade.

Não buscaremos aqui uma análise ampla, dogmática, sobre a evolução deste sistema de constitucionalidade, como elaborado com maestria na obra do professor Elival da Silva Ramos, mas utilizaremos os necessários aportes dos estudos realizados nesta senda para demonstrar como este incremento da função jurisdicional aproximou-a da análise e debate de questões que trouxeram consigo uma interpenetração de esferas de atuação, estanques no pensamento dos autores setecentistas e ainda bem preservadas no pensamento jurídico constitucional, sobretudo na experiência brasileira, do início e primeiros quartéis do século $\mathrm{XX}$.

Sob a égide da primeira Constituição do período republicano de 1891, com notável influência de Rui Barbosa, trazendo ao texto influência do sistema norte-americano, surge a figura do controle de constitucionalidade de caráter incidental e de efeitos concretos.

O art. 59, $\S 1^{\circ}, a$ e $b$ da Constituição de 1891 previu a competência do Supremo Tribunal Federal para rever por meio de recurso as sentenças das Justiças dos Estados, em última instância, quando questionada a validade ou a aplicação de tratados e leis federais, e a decisão do referido Tribunal for contra ela, e, em sua alínea $b$, a revisão em grau recursal das decisões do Tribunal do Estado quando esta considerar válidos leis ou atos dos Governos dos Estado, ou ainda leis federais, questionadas em face da Constituição.

A disposição do art. 59 reproduzia, com algumas modificações textuais, o julgamento incidental de inconstitucionalidade, previsto no Decreto n. 848 de 11 de outubro de $1890^{81}$.

\footnotetext{
${ }^{81}$ Dispunha o art. $3^{\circ}$ do Decreto 848 de 1890: "Na guarda e applicação da Constituição e das leis nacionaes a magistratura federal só intervirá em especie e por provocação de parte."
} 
Interessante destacar que o sistema de então consagrava o controle concreto de constitucionalidade, afastando quaisquer incursões no campo de um controle abstrato de normas. Nas palavras de Gilmar Ferreira Mendes, citando a lição de Rui Barbosa, pode-se observar um apego aos cânones clássicos da divisão dos Poderes, ainda que estivéssemos sob os auspícios de um sistema de controle de constitucionalidade:

\begin{abstract}
Convém destacar que era inequívoca a consciência de que o controle de constitucionalidade não se havia de fazer in abstracto. "Os tribunais - dizia Rui - não intervêm na elaboração da lei, nem na sua aplicação geral. Não são órgãos consultivos nem para o legislador, nem para a administração (...). E sintetizava, ressaltando que a judicial review "é um poder de hermenêutica, e não um poder de legislação",82.
\end{abstract}

De forma a preencher o arcabouço sistêmico do controle de constitucionalidade da Constituição de 1891, a Lei Federal n. 221 de 20 de novembro de 1894, completou a organização da Justiça Federal da República, previu a possibilidade, em verdade, o dever, dos juízes e tribunais deixarem de aplicar as leis e regulamentos incompatíveis com a Constituição, nos termos de seu art. $13, \S 10^{\circ}$.

Consoante lição de Elival da Silva Ramos:

\begin{abstract}
Tratava-se, com efeito, de um controle difuso, quanto ao aspecto orgânico ou competencial; incidental, concreto e subjetivo, quanto ao aspecto modal ou procedimental; gerador de decisões com efeito inter partes, decisões essas de natureza meramente declaratória, com aparência de retroatividade total, no plano da eficácia temporal, indicativas de nulidade ab initio e de pleno direito do ato impugnado ${ }^{83}$.
\end{abstract}

A Constituição de 1934 inseriu no sistema brasileiro regra semelhante ao full bench do direito norte-americano, ou cláusula de reserva de plenário, que em seu artigo 179 estatuía: "Só por maioria absoluta de votos da totalidade dos seus Juízes, poderão os Tribunais declarar a inconstitucionalidade de lei ou ato do Poder Público.”

Importante ponto trazido pela Constituição de 1934 diz respeito à possibilidade do Senado Federal, por provocação do Procurador Geral da República, de suspender a execução do

\footnotetext{
${ }^{82}$ BRANCO, Paulo Gustavo Gonet; MENDES, Gilmar Ferreira. Curso de Direito Constitucional. 7 a . ed. São Paulo: Saraiva, 2012. p. 1134.

${ }^{83}$ RAMOS, Elival da Silva. Controle de Constitucionalidade no Brasil: perspectivas de evolução. São Paulo: Saraiva, 2010. p. 187-8.
} 
ato impugnado e declarado inconstitucional, nos termos do art. 91, IV, e art. 96 da Constituição de 1934.

Ao analisar a Carta de 1934, Gilmar Ferreira Mendes traz importante observação em relação ao texto Constitucional de 1934, o que mostra novamente, a teor do exposto nas doutrinas clássicas analisadas nos parágrafos anteriores, uma opção, embora em clara evolução e crescimento rumo ao incremento e sofisticação dos mecanismo de controle, ainda bem distante daquilo que iríamos vislumbrar na atuação hodierna do Supremo Tribunal Federal: "Não se deve omitir, ainda, que a Constituição de 1934 continha expressa ressalva à judicialização das questões políticas, dispondo o art. 68 que 'é vedado ao Poder Judiciário conhecer das questões exclusivamente políticas", ${ }^{\text {. }}$.

Em termos evolutivos a Constituição de 1937 não trouxe relevantes mudanças ao sistema de controle de constitucionalidade, exceto pelo retrocesso trazido em seu art. 96, § único, o qual permitia ao Presidente da República espécie de revisão constitucional, outorgandolhe poderes para tornar sem efeito a decisão que declarava a inconstitucionalidade de lei ou ato, faculdade esta albergada nas cláusulas abertas da necessidade de "bem estar do povo, ou, à promoção ou defesa do interesse nacional de alta monta."

Com a reabertura democrática da Constituição de 1946 voltam-se novamente as atenções ao fortalecimento e evolução do sistema judicial de controle de constitucionalidade.

A Constituição de 1946 disciplinou hipóteses de cabimento do recurso extraordinário, instrumentando com detalhes este recurso, que fundamentalmente, servia de mecanismo de controle de constitucionalidade de caráter concreto.

Por certo a maior inovação da referida Carta foi a chamada representação interventiva, trazendo novamente figura já prevista na Constituição de 1934, outorgando-lhe contudo ampla utilização durante o período de vigência desta Constituição, ao contrário de sua predecessora de $1934^{85}$.

\footnotetext{
${ }^{84}$ BRANCO, Paulo Gustavo Gonet; MENDES, Gilmar Ferreira. Curso de Direito Constitucional. 7ª ed. São Paulo: Saraiva, 2012. p. 1136.

${ }^{85}$ Cabe aqui trazer a doutrina de Elival da Silva Ramos, o qual aponta diferença fundamental entre a figura prevista na Constituição de 1934 e a inovação trazida pela Constituição de 1946: "A sistemática foi, portanto, aprimorada pela Carta de 46, pois a verificação de constitucionalidade passou a dizer respeito ao ato estadual
} 
A chamada representação interventiva inova no sistema pela sua utilização como espécie de ação direta, de certa forma preparando o terreno para o surgimento do controle abstrato de normas por via de ação direta de inconstitucionalidade consagrado com a EC n. 16 de 1965 , caráter que chegou a ser delineado na representação interventiva de então ${ }^{86}$.

Com o advento da Emenda Constitucional 16 de 26 de novembro de 1965 a evolução de nosso Poder Judiciário dá uma largo passo ao rumos hoje ainda mais latentes de nosso sistema de controle de constitucionalidade, com todas as implicações que tal fator implica na impulsão da chamada atuação ativista da função jurisdicional, a consagração da ação direta de inconstitucionalidade, de viés abstrato, de controle de constitucionalidade.

Embora a nova ação direta de inconstitucionalidade tenha sofrido influência, ou tenha seu caminho aberto pela utilização da representação interventiva, há uma diferença fundamental, um avanço na natureza desta nova ação, trazendo um caráter de efeitos erga omnes e de declaração ex tunc de inconstitucionalidade. Neste sentido, o professor Elival da Silva Ramos, em excerto extraído da obra de Oswaldo Aranha Bandeira de Mello, traz clara diferenciação entre estas ações, fundamental para observarmos o ponto de evolução deste novo mecanismo advindo da EC n. 16 de 1965:

\footnotetext{
Na primeira consiste em ação de inconstitucionalidade, para declaração pelo Judiciário de ato Legislativo ou Executivo, porém na espécie, cujo efeito erga omnes só surge do ato do Congresso Nacional suspendendo os seus efeitos. Ao contrário, na última há ação de inconstitucionalidade em tese, com efeito erga omnes. A declaração em tese, com efeito erga omnes, deflui da decisão judicial, que se não restringe à suspensão dos seus efeitos, à sua revogação ex nunc, mas consiste em declaração de írritos e nulos e erga omnes, esses atos normativos, portanto, ex tunc ${ }^{87}$.
}

A nova via de controle tornara dispensável a intervenção do Senado para trazer efeitos erga omnes à declaração de inconstitucionalidade, este agora fazia parte da natureza da ação direta de caráter abstrato.

contraventor, previamente à decretação da intervenção por lei federal, enquanto sob o regime de 34 tal verificação tinha por objeto a própria lei interventiva, previamente à sua implementação pelo Presidente da República. (RAMOS, Elival da Silva. Controle de constitucionalidade no Brasil: perspectivas de evolução. São Paulo: Saraiva, 2010. p. 206)

${ }^{86}$ Idem, ibidem. p. 208.

${ }^{87}$ Idem, ibidem. p. 210-1. 
A Constituição de 1967 erigida durante o período do regime militar não trouxe grandes alterações ao nosso sistema de controle de constitucionalidade, mantendo o acesso ao Supremo Tribunal Federal por meio de controle incidental via recurso extraordinário: a representação interventiva, agora com titularidade para elaboração do Decreto interventivo ao Presidente da República, o qual teria de submetê-lo ao Congresso no prazo de cinco dias, nos termos do art. 11 e 12 da Constituição, e a ação direta de inconstitucionalidade, nos mesmos moldes propostos pela Emenda Constitucional 16 de 1965.

O professor Gilmar Ferreira Mendes em seu Curso de Direito Constitucional resume de forma clara e sucinta o quadro existente sob a égide da Constituição de 1967, cabendo aqui sua transcrição:

\begin{abstract}
A representação para fins de intervenção, confiada ao Procurador-Geral da República, foi ampliada, com o objetivo de assegurar não só a observância dos chamados princípios sensíveis (art. 10, VII), mas também prover a execução de lei federal (art. 10, VI, $1^{\mathrm{a}}$ parte). A competência para suspender o ato estadual foi transferida para o Presidente da República (art. 11, $2^{\circ}$ ). Preservou-se o controle de constitucionalidade in abstracto, tal como estabelecido pela Emenda n. 16/65 $(\text { art. } 119, \mathrm{I}, l)^{88}$.
\end{abstract}

Este é, em breves linhas, o quadro evolutivo que preparava o terreno para as fortes mudanças sentidas após a Constituição de 1988.

O texto constitucional de 1988 amplia o rol de legitimados para a propositura da ação direta de inconstitucionalidade, anteriormente reservada ao Procurador Geral da República, passando a ter legitimidade para propositura, além da figura anteriormente detentora desta atribuição, o Presidente da República, a Mesa do Senado, a Mesa da Câmara dos Deputados, a Mesa da Assembleia Legislativa, o Governador do Estado, o Conselho Federal da Ordem dos Advogados do Brasil, confederação sindical, entidade de classe de âmbito nacional, partido político com representação no Congresso Nacional.

A ampliação do rol de legitimados, bem como a figura do amicus curiae, prevista na Lei $\mathrm{n}^{\mathrm{o}}$ 9.868/99, em que pesem as críticas de parte da doutrina, certamente trazem certa democratização, ou mesmo, firmam, ao seu modo, um espaço deliberativo que tem

\footnotetext{
${ }^{88}$ BRANCO, Paulo Gustavo Gonet; MENDES, Gilmar Ferreira. Curso de Direito Constitucional. $7^{\text {a }}$. ed. São Paulo: Saraiva, 2012. p. 1143.
} 
assumido o Supremo Tribunal Federal, seja esta mudança benéfica ou não, possibilitando que este adentre, mediante provocação destes novos legitimados, em questões morais e de política governamental afetas aos interesses de diversos grupos representativos de setores da sociedade.

Exemplo claro pode ser extraído do julgamento da Ação Direta de Inconstitucionalidade 3.150, no qual travou-se um intenso debate envolvendo diversas entidades, tais como, Confederação Nacional dos Bispos do Brasil - CNBB, MOVITAE - Movimento em Prol da da Vida, dentre outros, ligadas a interesses que por vezes superam a questão técnicojurídica para adentrar ao campo das opções morais e políticas da sociedade.

Marca também de nossa atual Constituição foi o surgimento no âmbito do controle concentrado e abstrato da ação direta de inconstitucionalidade por omissão, cuja procedência acarreta a comunicação ao Poder competente para que adote as medidas cabíveis, e, da figura do mandado de injunção.

Sobre o mandado de injunção, cabe lembrar a evolução conceitual surgida desde seu advento, quando possuía, segundo entendimento exposto no julgamento do MI 107, julgado em 23.11.1989, caráter não concretista, pelo qual, procedente a ação, caberia a comunicação ao Poder competente para que elaborasse a norma necessária ao exercício do Direito.

Com o julgamento dos mandados de injunção n. 712/PA, 708/DF, 670/ES o STF passou a dar ao mandado de injunção caráter concretista, com efeitos erga omnes, em caso que, diante da omissão do legislador, aplicou aos servidores públicos a chamada Lei de Greve, criação legislativa destinada especificamente aos trabalhadores da iniciativa privada.

Nos casos individuais, alterando também a orientação histórica sobre o mandado de injunção, passou o STF, no julgamento do MI 721, a adotar posição concretista de caráter individual, aplicando ao impetrante o direito à aposentadoria especial pelo exercício de trabalho insalubre a trabalhador sob a égide do regime estatutário ${ }^{89}$.

\footnotetext{
${ }^{89}$ Sobre esta mudança de paradigma, Alexandre de Moraes aponta o exercício de ativismo judicial por força da nova postura assumida pelo Supremo Tribunal Federal. Nas palavras do professor da Faculdade de Direito do Largo de São Francisco: "em virtude da inércia do legislador em colmatar as lacunas
} 
Surge também, em seu art. 102, §único, a ADPF, arguição de descumprimento de preceito fundamental, cujo regramento, tendo em vista o caráter limitado de sua norma instituidora, nasce com a Lei 9.882 de 3 de dezembro de $1999 .{ }^{90}$

A nova ação direta permite o confronto em face dos princípios fundamentais contidos na Constituição quando houver relevante controvérsia constitucional sobre lei ou ato normativo federal, estadual ou municipal.

A arguição de descumprimento de preceito fundamental permite o confronto de normas anteriores à vigência da Constituição atual em face dos preceitos fundamentais nela contidos, confronto este que é vedado por meio da ação direta de inconstitucionalidade.

Importante ressaltar que a ADPF possui caráter de subsidiariedade em relação às demais ações diretas, dicção que se extrai do $\S 1^{\circ}$ do art. 4 da Lei 9.882/99, o qual dispõe "§ $1^{\circ}$ Não será admitida arguição de descumprimento de preceito fundamental quando houver qualquer outro meio eficaz de sanar a lesividade."

Mostra-se tormentosa na doutrina a delimitação do parâmetro de controle no âmbito desta nova ação constitucional, havendo divergência quanto ao alcance dos chamados preceitos fundamentais.

Mais uma vez, o caráter de nossa Constituição, de conteúdo semântico aberto, autoriza as mais diversas interpretações sobre os chamados preceitos fundamentais.

Elival da Silva Ramos aponta o caráter aberto do parâmetro de controle da arguição de descumprimento de preceito fundamental:

constitucionais, após 20 anos do texto constitucional, o Supremo Tribunal Federal alterou seu posicionamento e adotando claro ativismo judicial passou a adotar a posição concretista, tanto geral, quanto individual. (MORAES, Alexandre de. Direito Constitucional. 28 $8^{\mathrm{a}}$. ed. São Paulo: Atlas, 2012. p. 186)

${ }^{90}$ Para uma análise acurada das questões e críticas sobre a ação direta de inconstitucionalidade por omissão, mandado de injunção, e, sobretudo, sobre a arguição de descumprimento de preceito fundamental, vide a obra de Elival da Silva Ramos (RAMOS, Elival da Silva. Controle de Constitucionalidade no Brasil: perspectivas de evolucão. São Paulo: Saraiva, 2010). 
Sabe-se, de pronto, que não é toda norma constitucional que, uma vez descumprida, autoriza o uso da arguição, estando o instrumento voltado à tutela de preceitos fundamentais. Cuida-se, porém, à evidência, de conceito amplo e indeterminado, cuja destrinça pode ser sugerida pela doutrina, porém sem jamais atingir o nível de segurança que somente a prática do instituto permitirá. ${ }^{91}$

Sobre a definição dos preceitos fundamentais albergados como parâmetro de controle nesta ação direta, tem a doutrina apresentado diferentes posições quanto ao seu conteúdo ${ }^{92}$.

A Emenda Constitucional n. 3/93 traz a figura da ação declaratória de constitucionalidade, o avesso da ação direta de inconstitucionalidade, cuja procedência implica a declaração com efeitos erga omnes e vinculantes sobre a constitucionalidade do dispositivo de lei ou ato normativo federal. O rol de legitimados para sua propositura, em um primeiro momento mais restrito, passou a ser equiparado ao rol da ADI por força do advento da EC n. 45/2004, a qual inseriu também a legitimidade ao Governador do Distrito Federal e à Assembleia Legislativa do Distrito Federal para propositura de ambas ações.

Talvez mais profundas ainda tenham sido as mudanças sentidas com o advento das leis 9.868 de 10 de novembro de 1999 e 9.882 de 3 de dezembro de 1999, do que com o próprio texto constitucional de 1988. As referidas leis trouxeram mudanças sensíveis no âmbito do controle de constitucionalidade, fortalecendo sobremaneira o caráter abstrato de nosso sistema.

${ }^{91}$ RAMOS, Elival da Silva. Controle de Constitucionalidade no Brasil: perspectivas de evolucão. São Paulo: Saraiva, 2010. p. 327.

${ }^{92}$ José Afonso da Silva aponta que “'Preceitos fundamentais' não é expressão sinônima de 'princípios fundamentais'. É mais ampla, abrange estes e todas as prescrições que dão sentido básico do regime constitucional, como são por exemplo, as que apontam a autonomia dos Estados, do Distrito Federal, e especialmente as designativas de direitos e garantias fundamenteis". (SILVA, Afonso da. Curso de Direito Constitucional Positivo. São Paulo: Malheiros, 2002. p.558 ). Elival da Silva Ramos na já citada obra, os aponta como "'princípios fundamentais', do Título I, da CF; as normas-princípio do $\S 4^{\circ}$ do art. 60 e as que constituem seu desdobramento; e, finalmente, os princípios constitucionais sensíveis, arrolados no inc. VII, do art. 34, da Lei Maior."(RAMOS, Elival da Silva. Controle de Constitucionalidade no Brasil: perspectivas de evolucão. São Paulo: Saraiva, 2010, p. 327). Na visão de Gilmar Ferreira Mendes, "um juízo mais ou menos seguro sobre a lesão de preceito fundamental consistente nos princípios da divisão de Poderes, da forma federativa do Estado ou dos direitos e garantias fundamentais exige, preliminarmente, a identificação do conteúdo dessas categorias na ordem constitucional e, especialmente, das relações de interdependência. Nessa linha de entendimento, a lesão a preceito fundamental não se configurará apenas quando se verificar possível afronta a um princípio fundamental, tal como assente na ordem constitucional, mas também a disposições que confirma densidade normativa ou significado específico a esse princípio." (BRANCO, Paulo Gustavo Gonet; MENDES, Gilmar Ferreira. Curso de Direito Constitucional. 7ª ed. São Paulo: Saraiva, 2012. 
Em que pese a possibilidade do conhecimento da questão do controle de constitucionalidade por todos os juízes e instâncias do Poder Judiciário via controle difuso, e nisso reside o chamado caráter misto ou difuso de nosso sistema de controle judicial de constitucionalidade, a evolução de nossas Constituições e Legislação, sobretudo com os mecanismos legados pós-Constituição de 1988, aponta para uma tendência ao controle de caráter abstrato e concentrado de constitucionalidade.

Mais do que isso, ainda que se mantenha a possibilidade do controle difuso, o Supremo Tribunal Federal passou a ocupar grande parte da agenda política nacional, como local de debate das questões mais diversas, graças em parte ao incremento e à sofísticação deste sistema de controle jurisdicional de constitucionalidade.

No escólio de Manoel Gonçalves Ferreira Filho, as referidas leis "refletem mudanças quanto ao significado desse próprio controle no sistema constitucional, e, portanto, o papel ou função do Supremo Tribunal Federal, enquanto guarda da Constituição" ${ }^{\text {"93. }}$.

Se de um lado a Lei n. 9.882/99 trouxe regramento e aplicabilidade à norma da Constituição que instituiu em nosso sistema a arguição de descumprimento de preceito fundamental, a Lei n. 9.868/99 trouxe a disciplina processual do controle abstrato de normas.

A Lei Federal n. 9.868/99, de 10 de novembro de 1999, traz como pontos fundamentais, a figura do amicus curiae, a possibilidade de convocação de audiências públicas para esclarecimento de matéria ou circunstância de fato, podendo utilizar-se do auxílio de peritos ou mesmo "pessoas com experiência e autoridade na matéria", a possibilidade e o regramento da concessão de medidas cautelares no âmbito das ações diretas de constitucionalidade, dentre outros pontos, sendo extensa a disciplina do processo no âmbito destas ações.

Cabe ressaltar a previsão advinda do art. 27 da Lei 9.868/99, objeto de grande discussão e das mais diversas críticas no meio acadêmico e jurídico em geral, sobre a possibilidade de

\footnotetext{
${ }^{93}$ FERREIRA FILHO, Manoel Gonçalves. Aspectos do Direito Constitucional Contemporâneo. $3^{\mathrm{a}}$. ed. São Paulo: Saraiva, 2011. p. 235.
} 
modulação temporal dos efeitos da decisão de procedência da ação direta de inconstitucionalidade, nos termos do referido artigo, "tendo em vista razões de segurança jurídica ou de excepcional interesse social”.

Vale aqui colacionar a crítica sempre perspicaz do professor Manoel Gonçalves Ferreira Filho, ao analisar o disposto no art. 27 da referida lei:

O primeiro, inegável, consiste em registrar que o ato inconstitucional não é mais, como ensinavam doutrina e jurisprudência, nulo e írrito.

$[\ldots]$

E, mais. A decisão pode "restringir" os seus efeitos... Isto significa, por exemplo, que ela poderá considerar válidos atos inconstitucionais, ou dispensar o Estado de devolver o que percebeu em razão de tributo inconstitucionalmente estabelecido e cobrado... Donde resultará a inutilidade do controle. ${ }^{94}$

Prossegue ainda o autor:

O terceiro, insofismável, mostra que o controle de constitucionalidade assumiu um caráter político e que nele se pretende que o Supremo Tribunal Federal atue como órgão político.

$[\ldots]$

Disto tudo decorre, em suma, a conclusão de que o Supremo Tribunal Federal se torna (ou tende a se tornar) uma terceira Câmara do Poder Legislativo. ${ }^{95}$

As inovações da Lei 9.868/99 e Lei 9.882/99 tornaram ainda mais efetivo um processo de alargamento das fronteiras do exercício das funções do Poder Judiciário em matéria de controle de constitucionalidade, aparelhando-o como nunca dantes observado na história republicana brasileira.

O sistema de controle de constitucionalidade brasileiro em sua evolução assumiu caráter preponderantemente judicial-repressivo. A evolução do Poder Judiciário brasileiro, sobretudo no aspecto que interessa a este estudo, no desenvolvimento do aparato destinado ao controle judicial da supremacia da Constituição, mostra claramente que a figura do controle político ficou relegada a caráter secundário.

\footnotetext{
${ }^{94}$ FERREIRA FILHO, Manoel Gonçalves.Princípios Fundamentais do Direito Constitucional. 2a . ed. São Paulo: Saraiva, 2010. p. 248

${ }^{95}$ Idem, ibidem. p. 249.
} 
Até mesmo por uma observação empírica fica claro que o locus principal em que se decidem as questões de compatibilidade dos atos do governo e atos legislativos é o Poder Judiciário, em especial em sede de controle concentrado, no qual na última década tem-se utilizado largamente as ações diretas sobre questões de grande relevo da agenda nacional.

As reformas sentidas no âmbito de nosso sistema de controle de constitucionalidade pósConstituição de 1988 tornaram central o controle abstrato e concentrado de normas, em detrimento do controle incidental de caráter difuso.

Sobre esta mudança de eixo, acentua Gilmar Ferreira Mendes:

A Constituição de 1988 reduziu o significado do controle de constitucionalidade incidental ou difuso, ao ampliar, de forma marcante, a legitimação para propositura da ação direta de inconstitucionalidade (art. 103), permitindo que, praticamente, todas as controvérsias constitucionais relevantes sejam submetidas ao Supremo Tribunal Federal mediante processo de controle abstrato de normas.

\section{$[\ldots]$}

Assim, se se cogitava de um modelo misto de controle de constitucionalidade, é certo que o forte acento residia, ainda, no amplo e dominante sistema difuso de controle. O controle direto continuava a ser algo acidental e episódico dentro do sistema difuso.

A Constituição de 1988 alterou, de maneira radical, essa situação, conferindo ênfase não mais no sistema difuso ou incidente, mas ao modelo concentrado, uma vez que as questões constitucionais passam a ser veiculadas, fundamentalmente, mediante ação direta de inconstitucionalidade perante o Supremo Tribunal Federal ${ }^{96}$.

Na mesma seara, corrobora o entendimento de Rubens Beçak:

Com a Constituição de 1988, ocorreu evidente desbalanceamento do controle de constitucionalidade brasileiro - desde1965 considerado do tipo misto, prevendo a utilização tanto das matrizes difusa como da concentrada - tendo tomado o legislador constituinte acentuada preferência pelo sistema kelseniano, mormente o alargamento dos institutos previstos para a sua realização como também, gizese, a ampliação do rol de legitimados ativamente ad causam para sua proposição ${ }^{97}$.

\footnotetext{
${ }^{96}$ MENDES, Gilmar Ferreira. Jurisdição Constitucional: o controle abstrato de normas no Brasil e na Alemanha. $5^{\text {a }}$. ed. São Paulo: Saraiva, 2005. p. 89.

${ }^{97}$ BEÇAK, Rubens. Controle Difuso (Aspectos Gerais). In: Comentários à Constituição Federal de 1988. Coordenadores científicos: Paulo Bonavides; Jorge Miranda; Walber de Moura Agra. Coordenadores editoriais: Francisco Bilac Pinto Filho, Octávio Luiz Rodrigues Júnior. Rio de Janeiro: Forense, 2009. p. 1590.
} 
No mencionado artigo do professor livre docente da Faculdade de Direito do Largo de São Francisco, Rubens Beçak, é analisado o enfraquecimento do recurso extraordinário, o qual paulatinamente, pelo advento de mecanismos de filtragem como a repercussão geral, tem sua utilização reduzida dentro de nosso sistema de controle de constitucionalidade.

Corroborando ainda com o exposto, dando ainda mais autoridade à conclusão alçada, cabe trazer a lição de André Ramos Tavares:

Contudo, tem-se assinalado a tendência que, a partir de 1988, manifesta-se no Direito brasileiro no sentido de intensificar o controle concentrado da constitucionalidade, sem prejuízo do método difuso. Denotam essa tendência, no texto original de 1988, a ampliação da legitimidade ativa para a propositura da ação direta de inconstitucionalidade e a ampliação dos próprios instrumentos de controle abstrato-concentrado da constitucionalidade. Essa inclinação vai se intensificar com a EC n. 3/93, que criou a ação declaratória de constitucionalidade, e a EC n. 45/2004, que ampliou a legitimidade ativa desta última ação e criou a súmula vinculante ${ }^{98}$.

Sobre o advento das chamadas Súmulas Vinculantes ${ }^{99}$, a observação de André Ramos Tavares é precisa e traz mais um elemento que aponta este deslocamento de característica de nosso sistema de controle de constitucionalidade.

\begin{abstract}
Mais recentemente, com a criação da súmula vinculante, construiu-se uma ponte definitiva entre o controle difuso-concreto da constitucionalidade das leis e o controle abstrato-concentrado, já que as decisões proferidas no primeiro contexto poderão alcançar os efeitos próprios do segundo modelo, desde que sejam incorporadas no enunciado de uma súmula vinculante ${ }^{100}$.
\end{abstract}

É interessante notar esta tendência no Direito Constitucional brasileiro, o que demonstra que o Supremo Tribunal Federal tem alçado uma posição muito além de um órgão superior

\footnotetext{
98 TAVARES, André Ramos. Curso de Direito Constitucional. 9a. ed. rev. e atual. São Paulo: Saraiva, 2011. p. 308.

${ }_{99}$ Sob outra ótica, vale a transcrição do entendimento de Manoel Gonçalves Ferreira Filho sobre uma relação, assim entendida pelo autor, entre o advento das Súmulas Vinculantes e a atividade expansiva dos magistrados, ou utilizando a terminologia adotada neste trabalho, ativismo judicial: "Esta habilita o Supremo Tribunal Federal a editar súmulas de efeito vinculante sobre matéria constitucional, tendo por objeto a "validade, a interpretação e a eficácia de normas determinadas"(Constituição, art. 103-A). Tais súmulas, enunciados normativos escritos, são no fundo leis constitucionais interpretativas e possivelmente aditivas que se integram à Constituição efetiva do País. Vão além da mera jurisprudência que pode modificar-se evolutivamente, pois têm de ser revogadas, com a observância de um processo formal, como emendas constitucionais a que equivalem." (FERREIRA FILHO, Manoel Gonçalves. O papel político do judiciário e suas implicações. In: FRANCISCO, José Carlos. (coord. e coautor). Neoconstitucionalismo e atividade jurisdicional: do passivismo ao ativismo judicial. Belo Horizonte: Del Rey, 2012. p. 230).

100 TAVARES, André Ramos. Curso de Direito Constitucional. 9a . ed. rev. e atual. São Paulo: Saraiva, 2011. p. 310 .
} 
dentro da estrutura do Poder Judiciário para tornar-se foro deliberativo de todas estas questões albergadas em nosso bloco de constitucionalidade.

Todas estas engrenagens processuais alimentadas pela ampliação do acesso dos mais diversos legitimados à propositura destas ações constitucionais, têm tornado o Supremo Tribunal Federal verdadeiro foro de princípio, espaço deliberativo de questões fundamentais, ainda que sobre ele pairem fundadas objeções sobre seu caráter supostamente antidemocrático.

Pois bem, se a função jurisdicional assume um papel sólido durante o início da República no Brasil, e evolui rumo ao seu fortalecimento durante o transcorrer do século XX, parece claro, e aqui reside o segundo momento de evolução do Poder Judiciário destacado nos primeiros parágrafos deste capítulo, que é com o advento da Constituição de 1988, dada sua característica analítica, fruto de um amplo debate no qual foram inseridos em seu conteúdo inúmeras pautas representativas de múltiplos interesses, ${ }^{101}$ da presença de uma normatividade impregnada de cláusulas de conteúdo principiológico e axiomático abertos, aliado ao mencionado aprimoramento dos mecanismos do sistema judicial de controle de constitucionalidade, cuja sofisticação e amplitude atingem grau máximo pós-Constituição de 1988, que se dá o avanço do Poder Judiciário ao campo de questões políticas e legislativas, outrora legadas pura e tão somente ao exercício dos demais "Poderes".

Ao confrontarmos a atuação do Supremo Tribunal Federal pós-Constituição de 88 com os cânones apontados pelos autores mencionados no início do presente capítulo observa-se que o Poder que atuava somente para dirimir litígios de efeito concreto, que não adentrava em questões de natureza política, que somente funcionava como legislador negativo,

${ }^{101}$ Cabe aqui trazer à colação a análise do professor Elival da Silva Ramos, em sua obra Controle de Constitucionalidade no Brasil: perspectivas de evolução, em que ressalta, sem olvidar-se do fato de ser a Constituição de 1988 a mais debatida da história constitucional brasileira, uma característica que certamente traz elemento complicador no manejo deste texto constitucional: "Não é difícil perceber que a Carta de 88 se ressente, outrossim, de maior organicidade, agasalhando soluções normativas permeadas por interesses corporativos e paroquiais e unidas, o mais das vezes, por um cimento ideológico pouco aderente, fruto de compromissos assumidos erraticamente ao longo do penoso procedimento de votações." (RAMOS, Elival da Silva. Controle de constitucionalidade no Brasil: perspectivas de evolução. São Paulo: Saraiva, 2010. p. 226.

Torna-se evidente na observação da prática da jurisdição constitucional brasileira, sobretudo quando voltamos nossa observação aos julgamentos postos em sede de controle abstrato de normas, que a multiplicidade de pautas, de conteúdo aberto, representativas destes múltiplos interesses consagrados na Constituição, aliada ao princípio da Supremacia da Constituição e do exercício do controle de constitucionalidade por meio do Poder Judiciário como meio de sua preservação, trouxe ao campo do processo judicial a arena de debates e decisões outrora legadas à arena política da democracia representativa. 
possuindo até então ferramental acanhado no controle abstrato do alcance das normas e de sua compatibilidade com o entendimento dado por esta Corte ao texto constitucional, assume feições opostas, muito além da então imaginada atuação do Poder Judiciário idealizada pelos pais do constitucionalismo moderno, bem como, por aqueles que conformaram a instituição Judiciária desde o advento da República até as décadas finais do século XX.

É dentro deste novo quadro que passam a surgir de forma mais veemente questionamentos sobre a existência de uma distorção na balança da divisão dos poderes, de uma atuação do Poder Judiciário para além dos limites de seus parâmetros institucionais, de suas funções delineadas no desenvolver do constitucionalismo, sem que isto signifique um apego a formas estanques, mas sim um olhar sobre um desvio do núcleo essencial de sua função. 


\section{Poder Judiciário e Ativismo Judicial}

Com base nos delineamentos traçados no capítulo anterior, passamos a nos debruçar sobre uma análise deste novo Poder Judiciário, sobretudo em sua atuação nas grandes questões debatidas no âmbito do Supremo Tribunal Federal por meio deste amplo e rico instrumental processual destinado às ações de controle de constitucionalidade.

Por força do recorte adotado nesta dissertação, deixaremos de lado aqui observações sobre as mudanças e existência de um ativismo judicial nas instâncias ordinárias do Poder Judiciário, na chamada Jurisdição comum, em que pese a importância de uma análise das mudanças no perfil e na atuação destas instâncias ordinárias, sob os influxos de fenômenos comuns aos aqui abordados.

A título de reflexão sobre este ponto, se a questão coloca-se de forma por vezes problemática nas instâncias por assim dizer, mais preparadas, técnica e materialmente, ao enfrentamento deste novo bloco de constitucionalidade, cuja abertura dos conceitos e sua indeterminação é a maior tônica, imagine-se a problemática que nasce da atuação difusa desta espécie de controle, ou mesmo dos juízos de ponderação realizados ao longo de nossa extensa Federação, muitas vezes feitos em tábula rasa de sua real profundidade e complexidade que a questão demanda.

Do exposto até o presente momento, duas premissas são fundamentais e complementares à análise deste novo Poder Judiciário.

A primeira delas diz respeito a uma característica que talvez não seja exclusividade da Constituição de 1988, mas que com ela se aprofundou sobremaneira: a presença de conteúdo analítico desta Constituição, permeado por cláusulas abertas, de conteúdo axiológico amplo ${ }^{102}$.

\footnotetext{
${ }^{102}$ Oscar Vilhena Vieira aponta que a Constituinte de 1988 avançou para além das questões puramente constitucionais para adentrar em campos que, como observado nos parágrafos acima, ampliaram muito seu campo de incidência, e por consequência, trouxeram mudanças nas características do bloco de constitucionalidade. Em seu artigo, Supremocracia, o professor da Fundação Getúlio Vargas aponta esta questão como uma das razões desta "Supremocracia": "A primeira destas decisões diz respeito ao próprio ethos ambicioso da Constituição de 1988 que, segundo Seabra Fagundes, corretamente desconfiada do legislador, deveria sobretudo legislar. Assim, a Constituição transcendeu os temas propriamente constitucionais e regulamentou pormenorizada e obsessivamente um amplo campo de relações sociais,
} 
A Assembleia Constituinte de 1988 deu ao Poder Judiciário matéria-prima que lhe permite adentrar em questões morais que no mais das vezes residem no campo das opções políticas e legislativas da sociedade, ou que deveriam ser desenvolvidas em um processo de amadurecimento com ampla participação dos atores sociais.

Ao integrarem o bloco de constitucionalidade, cláusulas abertas e princípios de conteúdo amplo, muitas vezes interpretados com alto grau de discricionariedade por aqueles a quem incumbe sua aplicação, permitem uma margem de interpretação e de opção no exercício do controle de constitucionalidade que ampliam os limites da atuação deste juris dicere.

A segunda premissa complementar à primeira, reside na evolução dos mecanismos de controle de constitucionalidade expostos na capítulo anterior.

O aumento da utilização das ações diretas por meio do controle abstrato de constitucionalidade tem permitido um avanço das decisões judiciais em terrenos anteriormente não percorridos, sobretudo com as inovações trazidas pelas leis que deram regramento à ação direta de inconstitucionalidade e à arguição de descumprimento de preceito fundamental, o efeito vinculante das decisões a todas as esferas do Poder Judiciário e ao Governo e a possibilidade de modulação dos efeitos destas decisões.

Estes caracteres de nossa realidade constitucional nos colocam diante de um modelo estatal em que, a cada dia, o Poder Judiciário tem assumido importância maior e atuação ampliada, denotando um outro peso deste Poder na clássica balança idealizada por Montesquieu e adotada em todos os Estado erigidos sobre as linhas do Constitucionalismo Moderno.

Se esta nova realidade é um fato concreto ao qual não podemos negar vigência, cabe analisarmos se este rumo que tem tomado nossa balança dos Poderes mostra-se deletério aos cânones da democracia, pilar fundamental de nossa sociedade, e mesmo ao próprio desenvolvimento da função Judicante.

econômicas e públicas, em uma espécie de compromisso maximizador."(VIEIRA, Oscar Vilhena. Supremocracia. In: Rev. direito $G V$ [online]. vol.4, n.2, p. 446. 2008. ISSN 1808-2432). 
Mais do que uma análise binária e por vezes maniqueísta sobre o tema, faz-se necessário o aperfeiçoamento crítico sobre as condições em que esta nova realidade tem se desenvolvido. A concepção sob um viés, por assim dizer, pessimista destes novos cânones da função jurisdicional surgem nas críticas da doutrina comumente sob a nomenclatura de Ativismo Judicial.

Utilizamos aqui o conceito de ativismo judicial adotado por Elival da Silva Ramos, em sua obra Ativismo Judicial: Parâmetros Dogmáticos:

Ao se fazer menção ao ativismo judicial, o que se está a referir é a ultrapassagem das linhas demarcatórias da função jurisdicional, em detrimento principalmente da função legislativa, mas também, da função administrativa e, até mesmo, da função de governo ${ }^{103}$.

A observância da separação dos Poderes importa, dentre diversos outros consectários, na manutenção dos órgãos do Poder Judiciário nos limites da função jurisdicional que lhe é confiada e para cujo exercício foram estruturados 104 .

Ainda sobre o conceito do chamado ativismo judicial:

\begin{abstract}
Por ativismo judicial deve-se entender o exercício da função jurisdicional para além dos limites impostos pelo próprio ordenamento que incumbe , institucionalmente, ao Poder Judiciário fazer atuar, resolvendo litígios de feições subjetivas (conflitos de interesse) e controvérsias jurídicas de natureza objetiva (conflitos normativos). Há como visto, uma sinalização claramente negativa no tocante às práticas ativistas, por importarem na desnaturação da atividade típica do Poder Judiciário, em detrimento dos demais Poderes. Não se pode deixar de registrar mais uma vez que o fenômeno golpeia mais fortemente o Poder Legislativo, o qual tanto pode ter o produto da legiferação irregularmente invalidado por decisão ativista (em sede de controle de constitucionalidade), quanto o seu espaço de conformação normativa invadido por decisões excessivamente criativas ${ }^{105}$.
\end{abstract}

A abordagem dogmática contida na obra do professor da Faculdade de Direito do Largo de São Francisco nos dá a contribuição necessária e fundamental à abordagem aqui desejada, em que pese o presente trabalho não tratar de um olhar dogmático sobre a questão.

Os limites da atuação do Poder Judiciário se encontrariam, segundo a visão do referido autor, nos limites do próprio direito vigente, no qual a fundamentação das decisões

\footnotetext{
${ }^{103}$ RAMOS, Elival da Silva. Ativismo Judicial: parâmetros dogmáticos. São Paulo: Saraiva, 2010. p. 116

${ }^{104}$ Idem, ibidem. 2010, p. 117.

${ }^{105}$ Idem, ibidem. 2010, p. 129.
} 
judiciais deve encontrar balizas de acordo com as regras de hermenêutica para sua validade.

Se as decisões judiciais não são elaboradas livremente e se, tampouco, a discricionariedade do juiz é tão ampla quanto a do legislador, é nos limites substanciais que o próprio direito a aplicar lhe impõe que se há de buscar os critérios para a aferição do ativismo judiciário, nos termos já anteriormente $\operatorname{assinalados}^{106}$.

Dentre outros pontos abordados com maestria na análise de Elival da Silva Ramos, o autor identifica nas duas premissas postas no início do capítulo fatores de impulsão desta atividade ativista da função judicial.

Sobre a influência do controle abstrato de constitucionalidade, o qual tem se tornado, como já exposto, a tônica de nosso sistema, e a característica aberta de nossos preceitos constitucionais, expõe o constitucionalista do Largo de São Francisco:

A principal razão para tanto está na maior proximidade do controle de constitucionalidade, assim efetuado, do exercício da função legislativa, ainda que se trate, como já assinalado, do exercício de função jurisdicional. Com efeito, quer em uma hipótese como noutra, a decisão judicial sobre a validade da lei é emitida com efeitos gerais, ou erga omnes; de outra parte, quer no controle concentrado, que no controle abstrato em sistema difuso, registra-se a tendência a se admitir a modulação dos efeitos temporais das decisões sancionatórias da inconstitucionalidade; finalmente, a jurisdição constitucional, assim desenvolvida, interfere diretamente no conteúdo dos atos legislativos controlados. O exercício da fiscalização de constitucionalidade, nas condições apontadas, é fator desencadeante do ativismo judiciário na medida em que o órgão de controle perceba tornar-se menos nítida a distinção entre legislação e jurisdição $^{107}$.

Ademais, contribui como fator auxiliar da indução ao ativismo pelo controle concentrado ou pelo controle abstrato de normas a circunstância de que as normas parâmetro utilizadas pela Corte Constitucional (em sentido amplo) para apurar a validade da legislação fiscalizada são, em larga medida, máxime em sede de constitucionalidade material, normas-princípio, cuja formulação textual fluída permite ao órgão de controle maior liberdade de ação no exercício de sua função hermenêutico-concretizadora. A par disso, como já se constatou, o caráter eminentemente teleológico-valorativo dos princípios constitucionais e a força expansiva que lhes é inerente conduzem, com frequência, o órgão fiscalizatório ao balanceamento entre princípios de incidência simultânea para além de um simples ajuste entre os respectivos núcleos essenciais (o que competiria ao legislador fazer), bem como, ao desdobramento de seu significado de base, construindo disciplinas normativas que a eles se relacionam, mas que deles não decorrem $^{108}$.

\footnotetext{
${ }^{106}$ RAMOS, Elival da Silva. Ativismo Judicial: parâmetros dogmáticos. São Paulo: Saraiva, 2010. p. 134.

${ }^{107}$ Idem, ibidem. p. 277.

${ }^{108}$ Idem, ibidem. p. 277.
} 
Se a atividade jurisdicional deve encontrar sua validade na fundamentação dentro das balizas do próprio ordenamento jurídico, e se por outro lado, o sistema atual de controle de constitucionalidade permite ampla margem de atuação, aliado à matéria-prima posta à sua disposição, qual seja, cláusulas abertas e princípios constitucionais cuja tradução permitem a mais ampla variedade de conotações, parece clara a conclusão de que, o terreno é fértil à expansão do chamado ativismo judicial.

A necessidade de conformação da atividade judicial ao Direito como uma ideia sistêmica colide frontalmente com uma ordem jurídica cuja tônica é a imprecisão de seus conteúdos, e têm, portanto, as fronteiras de sua limitação alargadas, fronteiras estas que acabam por ser construídas por meio da tradução destas cláusulas abertas por parte de seu aplicador, no caso, o Poder Judiciário.

Como denota o entendimento de Elival da Silva Ramos, há um núcleo a ser respeitado dentro dos parâmetros do Direito positivo, bem como limites subjacentes à própria natureza da função judicial, os quais o ativismo acaba por fazer eclodir.

Sobre este ponto Alexandre de Moraes sintetiza aspectos fundamentais que impulsionaram a atividade ativista da Jurisdição, mormente sob o enfoque da experiência brasileira.

\begin{abstract}
No Brasil, a partir do fortalecimento do Poder Judiciário e da Jurisdição Constitucional pela Constituição de 1988 , principalmente pelos complexos mecanismos de controle de constitucionalidade e pelo vigor dos efeitos de suas decisões, em especial os efeitos erga omnes e vinculantes, somados à inércia dos Poderes Políticos em efetivar totalmente as normas constitucionais, vem permitindo que novas técnicas interpretativas ampliem a atuação jurisdicional em assuntos tradicionalmente de alçada dos Poderes Legislativo e Executivo.”. Prossegue o ilustre constitucionalista: "Principalmente, a possibilidade do Supremo Tribunal Federal em conceder interpretações conforme a Constituição, declarações de nulidade sem redução do texto, e, ainda, mais recentemente, a partir da edição da Emenda Constitucional n ${ }^{\circ} 45 / 04$, a autorização constitucional para editar, de ofício, Súmulas Vinculantes não só no tocante à vigência e eficácia do ordenamento jurídico, mas também em relação à sua interpretação, acabaram por permitir, não raras vezes, a transformação da Corte Suprema em verdadeiro legislador positivo ${ }^{109}$.
\end{abstract}

As observações acima reforçam a tese de que, ao contrário do sistema norte-americano, o qual há mais de um século convive com o debate em torno da questão, o avanço substancial dessa jurisdição, por assim dizer, ativista, se deu com as mudanças sentidas

${ }^{109}$ MORAES, Alexandre de. Direito Constitucional. 28a . ed. São Paulo: Atlas, 2012. p. 801. 
com a nova ordem constitucional de 1988, com as emendas constitucionais 3/1993 e 45/2004 e com as Leis 9.868/99 e Lei 9.882/99.

O fortalecimento do caráter abstrato do controle de constitucionalidade, não somente no incremento de seus mecanismos, mas na ampliação da legitimação para sua propositura, rompendo o monopólio até então do Procurador Geral da República, reduzindo a importância do controle difuso, permitiu que "praticamente, todas as controvérsias constitucionais relevantes sejam submetidas ao Supremo Tribunal Federal mediante processo de controle abstrato de normas" $" 110$.

Dentro de uma Constituição em que as mais diversas questões estão inseridas, protegidas por cláusulas e princípios constitucionais amplos, claramente há um deslocamento do locus de debate destas questões para o interior do processo objetivo de controle de constitucionalidade.

Neste ponto a função jurisdicional avoca para si o debate típico do processo político democrático.

Torbjorn Vallinder, em seu artigo When the Courts go marching in. aponta que a judicialização da política, termo comumente utilizado, assim como ativismo judicial, para apontar a interferência do Poder Judiciário sobre os campos da legislação e da conformação da vontade política, consiste em transformar algo, no caso, a política, em uma metodologia própria do processo judicial, por isso judicialização.

\footnotetext{
Thus the judicialization of politics should normally mean either (1) the expansion of the province of the courts or the judges at the expense of the politicians and/or the administrators, that is, the transfer of decision-making rights from the legislature, the cabinet, or the civil service to the courts or, at least, (2) the spread of judicial decision-making methods outside the judicial province proper. In summing up we might say that judicialization essencial involves turning something into a form of judicial process ${ }^{111}$.
}

A observação contida acima é importante ao apontar que não somente há uma transferência do locus de formação do decision making mas sim uma mudança do método de sua realização, passando a operar dentro de um método de natureza processual.

\footnotetext{
${ }^{110}$ MENDES, Gilmar Ferreira. Jurisdição Constitucional. $3^{\mathrm{a}}$. ed. São Paulo: Saraiva, 1999. p. 78.

${ }^{111}$ VALLINDER, Torbjörn. When the courts go marching in. In: TATE, C. Neal; VALLINDER, Torbjörn. The Global Expansion of Judicial Power. New York: New York University Press, 1995. p. 13.
} 
No enfoque em estudo, este método corresponde aos limites processuais e procedimentais das ações diretas, quando assumimos que é nesta senda que se realizam os grandes debates de questões fundamentais à sociedade.

Se esta nova feição do Poder Judiciário é uma realidade, cabe observar algumas das razões, além dos motivos de ordem técnico-jurídica, como as duas premissas acima firmadas, para a expansão deste Poder Judiciário.

Uma das razões claras reside no enfraquecimento da própria democracia sob o viés do sistema representativo experimentado na quase totalidade dos países ocidentais.

O Poder Judiciário avança às trincheiras dos Poderes Legislativo e Executivo em grande parte pela ineficiência destes órgãos no cumprimento das metas herdadas de uma geração de direitos sociais e prestações estatais as quais foram erigidas por meio de Constituições escritas como verdadeiras promessas revestidas com a natureza de normas jurídicas.

Oscar Vilhena Vieira aponta dentre outras razões para a expansão do Poder Judiciário o referido esvanecimento do sistema representativo.

\begin{abstract}
Uma segunda corrente enxerga a ampliação do papel do direito e do judiciário como uma decorrência da retração do sistema representativo e de sua incapacidade de cumprir as promessas de justiça e igualdade, inerentes ao ideal democrático e incorporadas nas constituições contemporâneas. Neste momento, recorre-se ao judiciário como guardião último dos ideais democráticos ${ }^{112}$.
\end{abstract}

Nesta mesma seara o professor da Vanderbilt University, C. Neal Tate, aponta uma espécie de delegação por parte dos Poderes representativos ao Judiciário para que assuma o papel de decision maker.

\footnotetext{
Occasionally, the judicialization of politics occurs when majoritarian institutions decide that there are certain issues that they do not wish to be burdened with deciding. Though the leadership of the majoritarian institutions might well deny it, it often appears toa $n$ outsider that this delegation is willful. Why do such delegations occurs? At times the reason appears to be that political costs of dealing seriously with the issue are too great risk, that the issue is a nowin proposition for elected decision makers. ${ }^{113}$
}

${ }^{112}$ VIEIRA, Oscar Vilhena. Supremocracia. In: Rev. direito $G V$ [online]. vol.4, n.2, p. 443. 2008. ISSN 1808-2432.

${ }^{113}$ TATE, C. Neal. Why the expansion of judicial power? In: TATE, C. Neal; VALLINDER, Torbjörn. The Global Expansion of Judicial Power. New York: New York University Press, 1995. p. 32. 
Delegating policies to the judiciary occurs in the context of a politics of rights the policies being delegated are otherwise too clearly within the normal discretion of majoritarian institutions to allow them to become the subject of judicial decision-making. In addition, the delegations may also represent the ineffectiveness of majoritarian institutions. However, one might also argue that failure to delegate these issues to the courts would only guarantee ineffectiveness of legislative or executive policy-making, since the issues would hamstring the majoritarian bodies and make it difficult for them to make any other kind of policy effectively ${ }^{114}$.

A abordagem do professor Tate se mostra atual e ressalta um ponto para além da mera inefetividade dos poderes Legislativo e Executivo, e, uma ausência de vontade política para a tomada de certas decisões, para as quais o custo eleitoral mostra-se elevado, podendo surtir efeitos indesejados àqueles que almejam por vezes somente as próximas eleições.

Talvez por esta razão questões como as reformas previdenciárias, política e tributária temse feito por meio de decisões judiciais, ainda que não revestidas sob o aspecto de ampla reforma, mas por certo pontualmente em questões cujo amplo debate político partidário mostra-se contra producente, e até mesmo, indesejado por aqueles que dele participam na qualidade de representantes da população.

Na mesma seara do apontado por Elival da Silva Ramos, Jorge Octávio Lavocat Galvão enxerga neste quadro um avanço da função judicial a campos outrora pertencentes a outras esferas deliberativas, consubstanciando sua atuação ativista.

Depois de 1988, com o fim do período ditatorial, a Suprema Corte tem decidido questões próprias dos poderes democraticamente eleitos. Esse fenômeno deve-se, entre outros, a dois motivos preponderantes. Em primeiro lugar, o poder constituinte e o legislador ordinário vêm alterando atribuições do Supremo Tribunal Federal por meio de edição de emendas constitucionais e de leis federais, de sorte a estabelecer um novo regime de jurisdição constitucional, que concentra poder político nesse órgão de cúpula do Judiciário. Esse novo regime privilegia o controle de constitucionalidade centralizado em detrimento do modelo de controle difuso, originalmente adotado pelo Brasil em 1891. Em segundo lugar, nos últimos anos, o próprio Supremo Tribunal Federal tem-se revelado cada vez mais "ativista", à míngua de críticas por parte da opinião pública $^{115}$.

${ }^{114}$ Idem, ibidem. p. 32-2.

${ }^{115}$ GALVÃO, Jorge Octavio Lavocat. Concentração de Poder da Jurisdição Constitucional: Uma análise crítica de seus pressupostos filosóficos. In: ALMEIDA, Fernando Dias Menezes de; AMARAL JÚNIOR, José Levi Mello do; LEAL, Roger Stiefelmann; HORBACH, Carlos Bastide (coord.). Direito Constitucional, Estado de Direito e Democracia: Homenagem ao Prof. Manoel Gonçalves Ferreira Filho. São Paulo: Quartier Latin, 2011. p. 366. 
É dentro deste quadro que assistimos, senão a uma proeminência do Poder Judiciário frente aos outros Poderes, a um avanço amplo de suas atividades ao campo de deliberação destas questões fundamentais.

Ainda corroborando com as já abalizadas exposições anteriores, o professor Manoel Gonçalves Ferreira Filho, cujo exercício da cátedra de Direito Constitucional tem contribuído para a formação de gerações de constitucionalistas de grande importância, em recente artigo, publicado na obra coletiva de organização do professor José Carlos Francisco, Neoconstitucionalismo e atividade jurisdicional: do passivismo ao ativismo judicial, traz importantes apontamentos sobre o fenômeno.

Ao abordar o fenômeno por ele chamado de atividade expansiva dos magistrados, ou ativismo judicial, Manoel Gonçalves aponta três fatores como causa desse fenômeno, sendo estes:

Uma, de ordem técnico-jurídica, é a expansão do controle judicial das políticas e atos administrativos, particularmente por meio da aferição de constitucionalidade.

Outra, de ordem sócio-política, reflete o desprestígio dos "políticos", em face do prestígio dos magistrados como uma "aristocracia togada", quer dizer, o contraste entre uma "plebe" despreparada e ávida e uma elite instruída, preocupada com o justo. Justo este confundido com o interesse geral.

Uma terceira, também de ordem sociopolítica, intimamente ligada à anterior, é auto-percepção dos magistrados como elite, com responsabilidade de trabalhar para o bem comum ${ }^{116}$.

Em especial ao caso brasileiro, Manoel Gonçalves Ferreira Filho agrega outros fatores específicos aos já mencionados no parágrafo anterior.

\footnotetext{
Neste, estão presentes as causas acima apontadas. Entretanto, a elas se soma o “estilo" da Constituição de 1988, suas ambiguidades, seus defeitos de redação, a imprecisão de sua linguagem, abundância de princípios cogentes, e, sobretudo, a multiplicação de instrumentos judiciais de atuação ou controle sobre as políticas de governo e sobre o proceder dos demais Poderes ${ }^{117}$.
}

${ }^{116}$ FERREIRA FILHO, Manoel Gonçalves. O papel político do judiciário e suas implicações. In: FRANCISCO, José Carlos. (coord. e coautor). Neoconstitucionalismo e atividade jurisdicional: do passivismo ao ativismo judicial. Belo Horizonte: Del Rey, 2012. p. 222-3.

${ }^{117}$ Idem, ibidem. p. 223. 
Dimitri Dimoulis, traz na mesma senda dos autores supracitados, visão que aponta a existência do chamado ativismo judicial neste novo fenômeno sentido sobremaneira após a Constituição de 1988.

(...) afirma-se que a principal característica da experiência jurídica brasileira após a promulgação da Constituição Federal de 1988 foi o fortalecimento do Poder Judiciário, segundo uma tendência que se manifesta em vários países, mas adquiriu particular intensidade no Brasil. O Judiciário concretiza a Constituição, aplicando-a diretamente em casos concretos, de acordo com aquilo que os Tribunais consideram como conteúdo dos princípios constitucionais. Isso criou o referido protagonismo do Poder Judiciário, simbolizado pela recente midiatização do Supremo Tribunal Federal, cuja atuação cotidiana tornou-se notícia central, sendo frequentes reportagens e entrevistas sobre os posicionamentos políticos e até mesmo sobre a vida privada de seus integrantes $^{118}$.

Essa mudança no equilíbrio entre poderes estatais tornou a atividade desenvolvida pelo Judiciário mais próxima da atuação do legislador positivo. $\mathrm{O}$ Judiciário muitas vezes supre lacunas deixadas pelo legislador ou até decide contrariamente ao estabelecido nos textos legais, suprindo também omissões do Legislativo. Temos uma situação, rotulada de ativismo judicial, que recebe os aplausos de grande parte da doutrina nacional, sendo minoritárias as críticas ${ }^{119}$.

Verifica-se dos excertos colacionados que uma visão sobre a aplicação dos princípios constitucionais tem dado espaço a esta atuação ativista de nossos tribunais, a qual adentraria na seara legislativa por meio de decisões que, buscando justificação nestas cláusulas abertas, encamparia o campo legislativo ou mesmo, decidiria de forma contrária ao sistema normativo.

A crítica em relação ao manejo destes princípios de textura aberta faz-se sobretudo em razão do modo como os mesmos têm sido manejados pela atividade jurisdicional, sem que sejam utilizados parâmetros claros, objetivos, o que torna fácil o transbordamento do núcleo essencial da função judicial para o campo da atividade legiferante ou executiva, agregando-se ainda o fator de uma possível desestruturação de uma metodologia de interpretação e aplicação do Direito, o que se verá nos capítulos seguintes, cedendo espaço a critérios subjetivos e voluntaristas. ${ }^{120}$

\footnotetext{
${ }^{118}$ DIMOULIS, Dimitri. Além do ativismo e do minimalismo judicial no campo dos direitos fundamentais. Justificação jurídica de decisões e competências. In: FRANCISCO, José Carlos. Neoconstitucionalismo e atividade jurisdicional: do passivismo ao ativismo judicial. Belo Horizonte: Del Rey, 2012. p. 262.

${ }_{119}^{19}$ Idem, ibidem. p. 262-3.

${ }^{120}$ Neste ponto, vale a menção a análise do professor Roger Stiefelmann Leal, na qual o professor da Faculdade de Direito do Largo de São Francisco traça uma crítica baseada na assunção da concepção monista de jurisdição do federalista Alexander Hamilton, a qual teria trazido inconvenientes ao funcionamento do sistema político, pelas implicações negativas advindas desta modelo. Segundo o autor: "A incorporação da
} 
A este quadro agrega-se os já mencionados efeitos erga omnes e vinculantes das decisões proferidas em sede de controle de constitucionalidade, a sistemática existente na atualidade com relação ao mandado de injunção, à arguição de descumprimento de preceito fundamental, a edição das súmulas vinculantes, lembrando aqui das observações dos professores Manoel Gonçalves Ferreira Filho e André Ramos Tavares sobre o tema, a possibilidade de modulação dos efeitos destas decisões, sem olvidar das técnicas decisórias adotadas, como por exemplo as decisões aditivas, a interpretação conforme à Constituição, mecanismos estes que podem e por vezes, na visão desta parcela da doutrina nacional, têm sido utilizados em flagrante ativismo judicial.

A visão encampada por autores como Jorge Octavio Lavocat Galvão, Elival da Silva Ramos, dentre outros autores, encontra seu contraponto naqueles que pugnam pela existência de um novo paradigma do Direito Constitucional cujas bases apontam pela superação dos cânones do constitucionalismo moderno, afirmando uma mudança vetorial, tanto sob o aspecto interpretativo e institucional, que justificaria as posturas objeto de crítica por aqueles que se contrapõem ao chamado ativismo judicial.

Dentro do necessário embate dialético destas posições opostas, passamos a adentrar a análise deste viés cada vez mais frequente na literatura do direito público brasileiro.

\subsection{A visão neoconstitucionalista}

Em artigo que se tornou importante ao estudo do tema, Luis Roberto Barroso abre sua explanação com a seguinte constatação:

jurisdição constitucional à jurisdição ordinária, proporcionada a partir da concepção monista ou unitária de Hamilton sobre a função judicial, gera preocupantes repercussões no funcionamento do sistema político. Além de conferir ao Judiciário posição proeminente no arranjo institucional, reconhece aos órgãos que têm função de aplicar a lei ao caso concreto a prerrogativa de se recusar a fazê-lo, mediante a construção de uma suposta ofensa ao texto constitucional. Basta à autoridade judicial, mediante o uso de um "álibi constitucional ad hoc", erigido a partir da abertura proporcionada por princípios constitucionais de amplíssima textura, afastar diploma legal que - segundo seus interesses, sentimentos e convicções configura óbice para uma "justa" resolução do caso" (LEAL, Roger Stiefelmann. O exercício da jurisdição constitucional pelo Poder Judiciário. In: ALMEIDA, Fernando Dias Menezes de; AMARAL JÚNIOR, José Levi Mello do; LEAL, Roger Stiefelmann; HORBACH, Carlos Bastide (coord.). Direito Constitucional, Estado de Direito e Democracia: Homenagem ao Prof. Manoel Gonçalves Ferreira Filho. São Paulo: Quartier Latin, 2011. p. 599). 
Talvez esta seja uma boa explicação para o recurso recorrente aos prefixos pós e neo: pós-modernidade, pós-positivismo, neoliberalismo, neoconstitucionalismo. Sabe-se que veio depois e que tem a pretensão de ser novo. Mas ainda não se sabe bem o que é. Tudo é ainda incerto. Pode ser avanço. Pode ser uma volta ao passado. Pode ser apenas um movimento circular, uma dessas guinadas de 360 graus ${ }^{121}$.

A assertiva do autor denota o tônica do neoconstitucionalismo ${ }^{122}$. Seus parâmetros mostram-se incertos, e de certa forma, vagos e abertos, em simetria aos novos parâmetros normativos abertos, com os quais, tanto aqueles que se filiam a esta corrente quanto aqueles que contra ela se opõem, se deparam em nosso atual quadro constitucional.

O professor da faculdade de direito da UERJ aponta ainda como transformações teóricas do neoconstitucionalismo:

\begin{abstract}
No plano teórico, três grandes transformações subverteram o conhecimento convencional relativamente à aplicação do direito constitucional: a) o reconhecimento de força normativa à Constituição; b) a expansão da jurisdição constitucional; c) o desenvolvimento de uma nova dogmática da interpretação constitucional $^{123}$.
\end{abstract}

Sobre a nova dogmática da interpretação constitucional, Barroso afirma haver uma superação do modelo de simples subsunção da normas, como regra abstrata, aos casos concretos, operação praticada pelo juiz, por uma interpretação composta de categorias como "cláusulas gerais, os princípios, as colisões de normas constitucionais, a ponderação e a argumentação" ${ }^{\prime 124}$.

Outro ponto essencial que permeia esta corrente do Direito Constitucional é a revalorização da moral como integrante do Direito.

\footnotetext{
${ }^{121}$ BARROSO, Luís Roberto. Neoconstitucionalismo e constitucionalização do direito (O triunfo tardio do direito constitucional no Brasil). In: Revista de Direito Constitucional e Internacional: Caderno de Direito Constitucional e Ciência Política, ano 15, n. 58, p. 130-1, janeiro-março/2007.

${ }^{122}$ Parece-nos certa a crítica de Elival da Silva Ramos ao negar a qualidade de movimento ou escola ao neoconstitucionalismo, situando-o no âmbito de um viés teórico. Em suas palavras: "O neoconstitucionalismo não chega a caracterizar um movimento ou escola, dada a falta de aglutinação de seus integrantes em torno de um corpo coerente de postulados ou de propostas, constituindo, quando muito, um viés teórico do Direito Constitucional." (RAMOS, Elival da Silva. Ativismo Judicial: parâmetros dogmáticos. São Paulo: Saraiva, 2010. p. 279).

${ }^{123}$ BARROSO, Luís Roberto. Neoconstitucionalismo e constitucionalização do direito (O triunfo tardio do direito constitucional no Brasil). In: Revista de Direito Constitucional e Internacional: Caderno de Direito Constitucional e Ciência Política, ano 15, n. 58, p. 134, janeiro-março/2007.

${ }^{124}$ BARROSO, Luís Roberto. Neoconstitucionalismo e constitucionalização do direito (O triunfo tardio do direito constitucional no Brasil). In: Revista de Direito Constitucional e Internacional: Caderno de Direito Constitucional e Ciência Política, ano 15, n. 58, p. 138, janeiro-março/2007.
} 
Este caráter moralista é citado em artigo da lavra de Thays Oliveira de Britto e Walber de Moura Agra, in verbis:

O neoconstitucionalismo propõe um modelo teórico para explicar o Estado Constitucional de Direito, caracterizando-se por negar teses juspositivistas da separação entre Direito e moral, procurando indicar parâmetros claros de concretização normativa que sofram o influxo de vetores metajurídicos ${ }^{125}$.

A corrente neoconstitucionalista é apontada, no mais das vezes por seus cultores, como a antítese do positivismo, ou como a solução para as crises que a lógica positivista de subsunção não teria logrado êxito em solucionar.

Quando confrontamos aquilo que foi apontado nos capítulos anteriores, a fluidez e a inflação de princípios e cláusulas abertas em nosso texto constitucional de 1988, com estas constatações da corrente neoconstitucionalista, ambos parecem formar um amálgama no qual resta o questionamento, se teria este movimento de revalorização da moralidade no Direito influenciado na adoção deste modelo em nosso texto constitucional, ou se este "movimento", absorve esta tônica de nossa constituição como o alimento necessário ao desenvolvimento de suas aspirações teoréticas.

Eduardo Cambi, endossa a tese sobre a existência de uma ruptura dos limites entre Direito e moral.

\footnotetext{
O neoconstitucionalismo promove a reaproximação do direito com a moral, buscando a concretização de valores compartilhados por toda a comunidade, em um certo momento e lugar, a fim de legitimar o exercício do direito enquanto instrumento de poder.

Rompe-se, portanto, a separação entre direito e moral, em favor de um gradualismo entre ambos, a ser buscado por intermédio de consensos a serem elaborados discursivamente, com o escopo de tornar possível a tese do construtivismo ético, a partir de parâmetros constitucionais ${ }^{126}$.
}

O autor adota a tese, também encampada pela maioria dos autores do chamado neoconstitucionalismo, de uma necessidade de atuação proativa do Poder Judiciário na

\footnotetext{
${ }^{125}$ AGRA, Walber de Moura; BRITTO, Thays Oliveira de. Neoconstitucionalismo. In: FRANCISCO, José Carlos. (coord. e coautor). Neoconstitucionalismo e atividade jurisdicional: do passivismo ao ativismo judicial. Belo Horizonte: Del Rey, 2012. p. 17

${ }^{126}$ CAMBI, Eduardo. Neoconstitucionalismo e neoprocessualismo: direitos fundamentais, políticas públicas e protagonismo judiciário. São Paulo: Revista dos Tribunais, 2009. p. 137.
} 
promoção dos direitos fundamentais, visando a realização de verdadeira justiça social por meio do processo, sobretudo com o rompimento da separação entre o direito e a moral.

Isto se revela no próprio nome da obra do autor, Neoconstitucionalismo $e$ neoprocessualismo: direito fundamentais, políticas públicas e protagonismo judiciário.

Este "protagonismo judiciário", usando aqui a terminologia adotada pelo autor, diz respeito ao deslocamento da responsabilidade na promoção dos direitos e compromissos assumidos pelo Estado Constitucional, sobretudo pela Constituição cidadã de 1988 ao Poder Judiciário, o qual assume o papel de tradutor destes axiomas e princípios, valendo aqui a observação de que princípios constitucionais e direitos fundamentais nem sempre são sinônimos, podendo estes últimos ser albergadores de regras, e não de princípios, e promovedores de sua aplicação social, sempre à luz da dignidade da pessoa humana, igualdade e outros vetores interpretativos albergados na Constituição.

O Poder Judiciário passar a ser o médium deste embricamento entre o Direito e Moral, e em sua atividade, passa a figurar como tradutor da moral em sua aplicação nesta nova lógica interpretativa.

Para que se faça a necessária demonstração, indispensável a este trabalho científico, transcrevemos trechos da obra do autor Eduardo Cambi que nos dão a exata percepção sobre o tema:

\begin{abstract}
A atividade interpretativa do juiz, pois, não deve se prender a um sistema hermenêutico fechado, devendo ser levado em consideração o contexto histórico social e interdisciplinar. Abandonar o império do modelo teórico logico-dedutivo do silogismo judiciário, sob este aspecto externo, significa aproximar o magistrado de questões políticas, imprescindíveis a uma interpretação axiológica do direito, desmitificando o mito da neutralidade do juiz e, principalmente, transformando o processo em um instrumento da democracia ${ }^{127}$.
\end{abstract}

Prossegue o autor:

A vigilância democrática dos juízes, aliada à independência do Judiciário, é requisito indispensável à promoção dos direitos humanos-fundamentais. Sem um Judiciário forte, a sociedade sucumbiria à tirania do poder. Prevaleceria a

${ }^{127}$ CAMBI, Eduardo. Neoconstitucionalismo e neoprocessualismo: direitos fundamentais, políticas públicas e protagonismo judiciário. São Paulo: Revista dos Tribunais, 2009. p. 120-1. 
opressão estatal e ficariam sem cumprimento os pactos internacionais e os direitos constitucionais que protegem a integridade dos direitos essenciais de todas as pessoas, não conferindo prevalência ao valor ético-jurídico da dignidade da pessoa humana ${ }^{128}$.

Ainda explorando o arcabouço teórico desta corrente, fazem-se importantes as observações do professor de direito constitucional da Universidade Presbiteriana Mackenzie, José Carlos Francisco.

Em artigo denominado (Neo) Constitucionalismo na Pós-Modernidade: Princípios Fundamentais e Justiça no Caso Concreto, o professor José Carlos Francisco aponta pesquisa realizada com magistrados brasileiros, a qual traz um perfil que pretensamente aponta uma tomada de partido por estes "novos cânones" da função judicial.

Ainda que as experiências neoconstitucionalistas e ativistas não tenham ganhado força em países europeus (especialmente na Espanha, na Itália, na França e em Portugal), esses pressupostos são presentes na realidade brasileira, pois dados colhidos em meados da década de 1990 revelaram que $83 \%$ dos magistrados brasileiros pesquisados acreditam que o Poder Judiciário não é neutro, e que em suas decisões o juiz deve interpretar a lei no sentido de aproximá-las dos processos sociais substantivos e, assim, influir na mudança social. Já 73,4\% dos magistrados entrevistados no Brasil "concordam inteiramente" ou "concordam muito" com a opinião de que o juiz não pode ser um mero aplicador das leis, pois tem de ser sensível aos problemas sociais, ainda que "apenas" $37,7 \%$ tenham se posicionado da mesma forma sobre a opinião de que "o compromisso com a justiça social deve preponderar sobre a estrita aplicação da lei”. Esses números mostram que a postura mecanicista de aplicação do texto normativo aos fatos concretos deixou de representar o modo de trabalho de proporção importante da magistratura brasileira ${ }^{129}$.

Sobre a mesma diversidade de conceitos, apontada por Luis Roberto Barroso no início deste capítulo, José Carlos Francisco aponta “ideias”, o que corrobora com o sentido difuso do movimento neoconstitucionalista.

Essa diversidade de conceitos de "neoconstitucionalismo" é consequência da associação dessa expressão a vários movimentos, vinculando diversas idéias tais como aplicação direta de princípios constitucionais aos casos concretos, fortalecimento do controle de constitucionalidade, busca de justiça na aplicação

\footnotetext{
${ }^{128}$ Idem, ibidem. p. 123.

${ }^{129}$ FRANCISCO, José Carlos. (Neo) Constitucionalismo na Pós-Modernidade: Princípios Fundamentais e Justiça no Caso Concreto. In: FRANCISCO, José Carlos (Coord. e coautor). Neoconstitucionalismo e atividade jurisdicional: do passivismo ao ativismo judicial. Belo Horizonte: Del Rey, 2012. p. 49-50.
} 
do direito, novas relações entre direito positivo e moral, neopositivismo ou póspositivismo, ponderação e teoria da argumentação ${ }^{130}$.

José Carlos Francisco identifica quatros fatores históricos fundamentais ao surgimento do neoconstitucionalismo: a inserção de princípios nas Constituições pós-segunda grande guerra, as quais com o fortalecimento das Cortes Constitucionais contribuíram para a valorização da justiça material e de medida contra o arbítrio do legislador ordinário; a formação de blocos transnacionais, dentro dos quais a abertura semântica dos enunciados permitiu a adaptação à realidade de cada um dos países; o pluralismo das relações sociais, e, por último, a incapacidade do legislador de prever a totalidade das situações fáticas dentro de uma sociedade dinâmica e complexa ${ }^{131}$.

É interessante destacar que o autor identifica o neoconstitucionalismo como advindo de uma necessidade histórica, ao mencionar que "o neoconstitucionalismo é uma construção feita a partir de necessidades mostradas por fatos históricos, e não um artifício teórico" ${ }^{\text {"132. }}$.

Os apontamentos realizados por meio da citação dos referidos autores, nos permitem, dentro deste amálgama de ideias que compõem este viés do direito constitucional, identificar alguns pontos fundamentais à abordagem pretendida neste trabalho.

O primeiro deles reside no chamado "protagonismo judiciário", tomando emprestada a terminologia utilizada por Eduardo Cambi.

Embora haja diferentes matizes de pensamento naqueles que total ou ainda parcialmente aderem ao chamado neoconstitucionalismo, a figura do Poder Judiciário se mostra central, de certa forma hipostasiada em relação às demais funções clássicas do $\operatorname{Estado}^{133}$.

\footnotetext{
${ }^{130}$ FRANCISCO, José Carlos. (Neo) Constitucionalismo na Pós-Modernidade: Princípios Fundamentais e Justiça no Caso Concreto. In: FRANCISCO, José Carlos (Coord. e coautor). Neoconstitucionalismo e atividade jurisdicional: do passivismo ao ativismo judicial. Belo Horizonte: Del Rey, 2012. p. 54.

${ }^{131}$ Idem, ibidem. p. 60-1.

${ }^{132}$ Idem, ibidem. p. 59.

${ }^{133}$ Vale mencionar trecho extraído de do artigo intitulado Neoconstitucionalismo e constitucionalização do direito (O triunfo tardio do direito constitucional no Brasil) no qual se afirma esta valorização do Poder Judiciário: "Uma das instigantes novidades do Brasil dos últimos anos foi a virtuosa ascensão institucional do Poder Judiciário. Recuperadas as liberdades democráticas e as garantias da magistratura, juízes e tribunais deixaram de ser um departamento técnico especializado e passaram a desempenhar um papel político, dividindo espaço com o Legislativo e o Executivo. Tal circunstância acarretou uma modificação substantiva na relação da sociedade com as instituições judiciais, impondo reformas estruturais e suscitando questões complexas acerca da extensão de seus poderes". (BARROSO, Luís Roberto. Neoconstitucionalismo e constitucionalização do direito (O triunfo tardio do direito constitucional no Brasil). In: Revista de Direito
} 
Há certo consenso no fato de que haveria um novo paradigma do Direito Constitucional, no qual as regras de subsunção clássicas dariam lugar às teorias argumentativas, dentre as quais encontram-se diferentes graus e métodos, à tópica ou mesmo à utilização constante de juízos de ponderação como integrantes de uma nova hermenêutica constitucional.

Estas observações permitem concluir que aos autores desta vertente do Direito Constitucional, o deslocamento ao Poder Judiciário de questões fundamentais que dizem respeito ao projeto político da nação, ao implemento de políticas públicas e à interpretação e tradução dos diversos axiomas presentes na Constituição, não se constituiria em distorção ao princípio da separação dos poderes, ou mesmo em ativismo judicial, adotando aqui a carga pejorativa do termo, mas sim uma nova realidade jurídico-constitucional.

Não se deve olvidar que entre estes mesmos autores há ressalvas quanto a atuação do Poder Judiciário. Não se deseja aqui incorrer em reducionismos, em que pese o âmbito restrito de abordagem sobre o tema, o qual comportaria uma dissertação destinada somente à sua análise, mas algumas observações devem ser feitas.

Eduardo Cambi ressalta a necessidade da adoção de critérios de correção por meio de uma teoria da argumentação que afaste este Judiciário, proeminente, dos riscos do subjetivismo ou do mero decisionismo.

O método concretista aposta na teoria da argumentação como forma de
concretização da norma jurídica. Tal teoria evita, de um lado, que se confunda o
texto legislativo com a norma (resultado de interpretação). De outro, inibe o
subjetivismo e o decisionismo, pois não resulta na possibilidade do intérprete
"dizer qualquer coisa sobre qualquer coisa". Não sendo admissível que as
decisões judiciais sejam tomadas a partir de impulsos ou fatores puramente
emotivos. Tampouco deve ser considerada adequada a motivação calcada em
citação vaga de princípios jurídicos (como ocorre, usualmente, com os princípios
da dignidade da pessoa humana ou da razoabilidade), desacompanhada da
criteriosa análise do caso concreto e de argumentação jurídica sólida. O
neopositivismo não deve dar margem para o subjetivismo dos intérpretes,
fazendo imperar a desordem e a descrença na Constituição ("oba-oba
constitucional). Pela teoria da argumentação, permite-se que, no processo
judicial, sejam discutidos os limites hermenêuticos, contidos na própria
constituição, para atuação legítima da jurisdição constitucional, exigindo que as
partes e órgão judicial se desincumbam de seus ônus argumentativos, os quais

Constitucional e Internacional: Caderno de Direito Constitucional e Ciência Política, ano 15, n. 58, p. 166-7, janeiro-março/2007). 
devem ser tanto mais intensos quanto mais forem vagas as normas a serem aplicadas $^{134}$.

Esta análise, perfunctória se comparada à vasta produção bibliográfica sobre o tema, corrobora com o apontado anteriormente, no sentido de que, a matéria-prima dos operadores do Direito sofreu um alargamento de seus parâmetros de aferição.

O caráter aberto das normas constitucionais, e portanto do bloco de constitucionalidade posto para o exercício da Jurisdição Constitucional, é um fato inegável por parte da doutrina, seja por aqueles que veem neste fator um desejado instrumental para o crescimento da função judicial, seja para aqueles que veem neste ponto um problema a ser resolvido, sob um viés negativo da questão que tende a colocar em xeque os cânones da democracia e de princípios fundamentais do constitucionalismo moderno, como a separação de poderes.

Antes de adentrarmos nesta análise, que coloca a Jurisdição Constitucional como o local central no debate sobre estas cláusulas abertas e as implicações desta realidade, faremos ainda breves considerações, sobre a crítica a este neoconstitucionalismo.

\subsection{A antítese ao neoconstitucionalismo}

Cremos que não há que se fixar em uma análise dicotômica, polarizando o debate entre aqueles que enxergam na atividade jurisdicional, para além dos limites clássicos do constitucionalismo moderno, um risco ao Estado de Direito, à própria ideia de Constitucionalismo, e à Democracia, situando-os como anti neoconstitucionalistas, e aqueles que veem com naturalidade esses novos rumos da função Judicial, deixando-os em um círculo fechado de pretensos autores neoconstitucionalistas, principalmente porque, não há consenso na doutrina sobre a existência deste neoconstitucionalismo, mesmo entre aqueles que adotam uma visão mais receptiva à dita atuação ativista do Poder Judiciário.

Contudo, ainda que não se queira aqui albergar diferentes posições em dois blocos estanques, é certo que os aportes feitos por autores do chamado neoconstitucionalismo

\footnotetext{
${ }^{134}$ CAMBI, Eduardo. Neoconstitucionalismo e neoprocessualismo: direitos fundamentais, políticas públicas e protagonismo judiciário. São Paulo: Revista dos Tribunais, 2009. p. 111.
} 
atingem de forma central o ponto de reflexão aqui almejado, tendo em seu contraponto aqueles que a esta visão se opõem.

Para uma crítica às exposições neconstitucionalistas trazidas no capítulo anterior, cabe demonstrar a visão de importante parcela do pensamento jurídico constitucional brasileiro.

Elival da Silva Ramos credita a esta corrente um fator de impulsão ao ativismo judicial.

\begin{abstract}
Vislumbram-se no esboço propositivo neoconstitucionalista as tintas de um fluido moralismo jurídico, que "não despreza o direito posto", mas que o descarta, se necessário for, para que prevaleça a ordem objetiva de valores a que prestam vassalagem. Cuida-se sim de um jusnaturalismo mitigado, em que se propugna o distanciamento de categorias metafísicas ou do subjetivismo axiológico, para buscar a racionalidade argumentativa (à Alexy) ou na experiência histórica (à Dworkin) um mínimo de objetividade ética que permita a superação (em determinadas circunstâncias, apenas) da objetividade do direito legislado.

A principiologização do direito, característica do moralismo, desponta como a face mais visível desse pretenso "pós-positivismo" tupiniquim, abrindo as portas do sistema jurídico ao subjetivismo de decisões judiciais que, valendo-se de contornos menos nítidos das normas-princípio e potencializando-lhe os efeitos para além do que seria lícito fazer, deixam de concretizar a Constituição para, a bem ver, construí-la, ao sabor das preferencias axiológicas de seus prolatores.
\end{abstract}

Nas transcrições acima podemos identificar o ponto nevrálgico da problemática proposta no presente trabalho, sobre o qual iremos avançar mais propriamente nos dois capítulos seguintes.

Esta moralização ou principiologização do Direito abriria o campo necessário para que o Poder Judiciário avançasse suas fronteiras ao espaço nuclear dos demais poderes clássicos, em especial o Legislativo.

O ferramental está posto, um sistema de controle de constitucionalidade amplo, dotado de sofisticados meios processuais, cujas reformas pós-Constituição de 1988 permitiram uma ampliação de seu campo de abrangência, seja quantitativamente ou qualitativamente, e, de outro lado, sua matéria prima é constituída de preceitos fluídos, cláusulas abertas, e de uma Carta que buscou abarcar em seu corpo os mais diversos direitos, tornando-a extremamente extensa. 
Endossando a crítica de Elival da Silva Ramos, Carlos Bastide Horbach em artigo denominado A nova roupa do Direito Constitucional, pós positivismo e outros modismos traz indispensáveis considerações.

Carlos Bastide Horbach aponta que esta atuação do Poder Judiciário identificada por parcela da doutrina como ativismo judicial, embora não utilize esta nomenclatura, decorre de problemas no desenho institucional das funções no Direito brasileiro, bem como, a uma “crise de mentalidade"135, a qual é objeto de análise no referido artigo.

O citado autor compara os elementos apontados por Luis Roberto Barroso, em seu texto $O$ começo da História. A nova interpretação constitucional e o papel dos princípios no direito brasileiro com as lições extraídas da obra clássica de Carlos Maximiliano, Hermenêutica e aplicação do Direito, demonstrado que os princípios aventados como integrantes desta nova hermenêutica constitucional, quais sejam, o princípio da supremacia da Constituição, princípio da presunção de constitucionalidade das leis e atos do poder público, princípio da interpretação conforme a Constituição, princípio da Unidade da Constituição, princípio da efetividade, e, princípio da razoabilidade ou proporcionalidade, seriam nada mais do que os tradicionais métodos de interpretação constitucionais travestidos em uma nova roupagem, a nova roupa do Direito Constitucional, em analogia à fábula de Hans Christian Andersen, A Nova Roupa do Rei ${ }^{136}$.

Da crítica aguda de Horbach, cabe a transcrição de dois trechos nos quais o autor liga este fator às já mencionadas características de nosso texto constitucional.

\footnotetext{
Não sendo a "nova hermenêutica constitucional" uma teoria com traços próprios, caracteriza-se como uma formulação retórica que busca justificar uma realidade, qual seja, a extrapolação indevida das funções jurídico-políticas, em especial pelos responsáveis pela interpretação das leis e da Constituição, num claro movimento ideológico ${ }^{137}$.

À retórica perniciosa do "neo-constitucionalismo" e à vulgata brasileira da sociedade aberta dos intérpretes alia-se ainda um outro fator: A extensão analítica do texto constitucional e a indeterminação de muitos de seus preceitos $^{138}$.
}

\footnotetext{
${ }^{135}$ HORBACH, Carlos Bastide. A nova roupa do Direito Constitucional, pós positivismo e outros modismos. In: Revista dos Tribunais, v. 859, ano 96, p. 83, maio de 2007.

${ }^{136}$ Idem, ibidem. p. 87

${ }^{137}$ HORBACH, Carlos Bastide. A nova roupa do Direito Constitucional, pós positivismo e outros modismos. In: Revista dos Tribunais, v. 859, ano 96, p. 88, maio de 2007.

${ }^{138}$ Idem, ibidem. p. 89.
} 
Percebe-se que a pretensa teoria engendrada pelo neoconstitucionalismo, segundo a visão adotada pelo autor, corresponde mais a um projeto ideológico do que realmente a um novo paradigma do Direito, mormente pela utilização de critérios hermenêuticos e parâmetros já conhecidos pelo Constitucionalismo e Hermenêutica por assim dizer, clássicos.

Jorge Octávio Lavocat Galvão, em sua Tese apresentada no ano de 2012 no curso de Doutorado na Faculdade de Direito do largo de São Francisco, identifica, mesmo diante dos diferentes matizes de pensamento que envolvem a temática do neoconstitucionalismo, elementos centrais e comuns àqueles que adotam este viés.

\begin{abstract}
(...) percebe-se haver uma constância temática nos trabalhos dos autores ditos neoconstitucionalistas. A crença na emancipação social por meio da jurisdição constitucional faz com que os diversos autores festejem os instrumentos que conferem uma maior liberdade aos juízes para interferir na realidade social. A aplicação direta da Constituição, a valorização dos princípios, a constitucionalização do ordenamento jurídico, a aplicação horizontal dos direitos fundamentais e a técnica da proporcionalidade são vistos com bastante otimismo por todos eles. Obviamente, essa manifestação de preferência por tais mecanismos é uma atividade valorativa por parte desses intérpretes. Da mesma forma, a crescente produção doutrinária sobre os referidos institutos, bem como suas aplicações aos casos concretos, não podem ser vistas como um desenvolvimento natural do constitucionalismo. Não são fatos puros, mas escolhas do intérprete ${ }^{139}$.
\end{abstract}

A leitura do excerto da obra de Jorge Lavocat Galvão nos remete, na mesma senda das observações de Elival da Silva Ramos e Carlos Bastide Horbach, a uma conclusão comum por parte destes doutrinadores, no sentido de que, a hipervalorização destes métodos interpretativos, a leitura realizada por esta parcela da doutrina, leva a crer em uma opção, uma escolha dos intérpretes por este viés, cuja tônica parece se fechar em um círculo entre protagonismo judiciário, utilização de amplos meios processuais e hermenêuticos no manejo desta "matéria-prima" subjacente à Constituição de 1988, consistente em cláusulas abertas e seu caráter analítico, extenso na regulação social.

Dentro desta ótica, a teoria neoconstitucional promove e vê de forma promissora, a transferência para o Poder Judiciário, sobretudo no âmbito do controle de constitucionalidade, da discussão de questões morais amplas pertinentes aos rumos da

${ }^{139}$ GALVÃO, Jorge Octávio Lavocat. O neoconstitucionalismo e o fim do Estado de Direito. Tese de doutorado. Faculdade de Direito da Universidade de São Paulo. São Paulo, 2012. p. 81. 
sociedade, para além dos cânones normativos mais estritos, privilegiando a atuação do Poder Judiciário naquilo que chamam seus críticos de ativismo judicial.

No caso do Neoconstitucionalismo, está claro que se trata de uma teoria cujo principal foco é a substância das decisões. Sua vocação é ser uma teoria transformadora, voltada para a reforma da sociedade, valorizando o ativismo judicial e a mudança social em detrimento dos valores da democracia e da segurança jurídica ${ }^{140}$.

O choque entre os valores da democracia e esta nova atuação do Poder Judiciário far-se-ia em virtude da transferência à função judicial, desprovida de caráter democrático e participativo, da competência para decidir questões além dos limites do ordenamento.

A questão se torna tormentosa quando por força dos novos parâmetros de controle de constitucionalidade os próprios limites normativos da Constituição e do ordenamento jurídico tornam-se de difícil percepção.

Esta observação não escapa à crítica do autor:

\begin{abstract}
Ao incitar os intérpretes a rediscutirem judicialmente os méritos dos compromissos políticos assumidos pela sociedade, o Neoconstitucionalismo está em constante tensão com esse ideal político em dois sentidos: primeiro, ao colocar em xeque a validade de todas as normas jurídicas, deixando os cidadãos desorientados sobre como agir, segundo, ao pulverizar o critério normativo mediante os quais os litígios sobre a aplicação dessas mesmas normas serão $\operatorname{decididos}^{141}$.
\end{abstract}

Como já afirmado, as críticas postas parecem aglutinar-se em face dos vetores teóricos do movimento neoconstitucionalista, mesmo que nem todos os autores mais adeptos de um Poder Judiciário ativista filiem-se ou endossem a nomenclatura do chamado neconstitucionalismo.

Isto justifica a opção pela abordagem aqui adotada, pois em ambos os discursos verificamos o confronto de visões que nos colocam diante do ponto de estrangulamento da questão, objeto desta Dissertação.

\footnotetext{
${ }^{140}$ Idem, ibidem. p. 131.
}

${ }^{141}$ Idem, ibidem. p. 134. 
Dentre esses aspectos e causas do chamado ativismo judicial, ressaltamos aquele que nos parece um dos principais pontos, causador de uma possível tensão frente aos postulados democráticos, a transformação do Poder Judiciário em tradutor e intérprete de valores e conteúdos morais fundamentais da sociedade.

É neste campo que o avanço deste Poder tem se mostrado mais amplo, na mesma medida e proporção da amplitude de nosso texto constitucional e tem recebido críticas por parte dos estudiosos do tema, como já se pôde perceber do até aqui desenvolvido.

A apatia do sistema representativo, exercido pelo poder Legislativo, aliado a este novo espectro do Judiciário deslocou o debate destas questões ao Poder Judiciário, tornando-se a última e mais importante trincheira de debate das questões fundamentais da sociedade, muito além de uma atuação focada na análise de um Direito como um sistema de normas hermético que permitisse o exercício de suas funções por meio de critérios precisos e puramente dogmáticos. 


\section{O PODER JUdiciáRIO COMO INTÉRPRETE DE VALORES DA SOCIEDADE}

O arcabouço teórico explorado nos capítulos anteriores permite, a constatação de um dado que parece invariável, sejamos nós adeptos de um Judiciário ativista ou refratários a ele.

Esta constatação reside no fato de que o Poder Judiciário, mormente em suas Cortes Superiores, tornou-se o foro de discussão e tradução de todos os valores e conteúdos amplos subjacentes às normas constitucionais, o que dentro de um modelo de sociedade da qual Constituição reflete com espelho os diversos interesses que a compõem, torna-o em médium dos valores da própria sociedade.

A título introdutório cabe trazer os necessários aportes sobre a designação valores, para que possamos melhor delimitar o objeto desta análise.

Carl Schmitt afirma que "el valor no es, sino vale" $" 142$. Prossegue o constitucionalista alemão ao afirma que "el valor, sin embargo, implica una afán muy flerte a la realización [...] El valor tiene realmente ansia de actualización. No es real, pero está relacionado con la realidad y está al acecho de ejecución y cumplimiento"143.

Miguel Reale acentua a impossibilidade de definição de um conceito claro de valor, afirmando que "do valor se pode dizer apenas que vale"144.

Em sua clássica obra Filosofia do Direito, são apontadas características que compõem a estrutura dos valores, as quais nos auxiliam a delimitar sua noção fundamental.

Valores são bipolares, "porque a um valor se contrapõe um desvalor" ${ }^{145}$. Além de bipolares, os valores são dotados de implicação, "no sentido de que nenhum deles se realiza sem influir, direta ou indiretamente, na realização dos demais"146.

\footnotetext{
${ }^{142}$ SCHMITT, Carl. La Tirania de los Valores. Anima Schmitt de Otero (Trad.). In: Revista de Estudios Politicos, Madrid, 115, p. 68, Enero-Frebrero/1961.

${ }^{143}$ Idem, ibidem. p. 68. .

${ }^{144}$ REALE, Miguel. Filosofia do Direito. 20a. ed. São Paulo: Saraiva, 2002. p. 187.

${ }^{145}$ Idem, ibidem. p. 189.

${ }^{146}$ Idem, ibidem. p. 189.
} 
O mundo ideal dos valores, possui ainda a característica de referibilidade, o que significa que "o valor implica sempre uma tomada de posição do homem e, por conseguinte, a existência de um sentido" ${ }^{147}$. Os valores contém uma chamada graduação hierárquica, de forma que "toda sociedade obedece a uma tábua de valores, de maneira que a fisionomia de uma época depende da forma como seus valores se distribuem ou ordenam"148.

Os elementos de bipolaridade, referibilidade, implicação e graduação hierárquica nos mostram que os valores são vetores de orientação da conduta humana que por sua natureza implicam em escolhas e rejeições por parte daqueles que os traduzem do plano imaterial à realidade fática.

Dentro do processo nomogenético da teoria tridimensional do Direito ocorre a chamada dialética de implicação polaridade, no qual esta valoração implica no resultado da formação da norma, médium entre os valores escolhidos e traduzidos pelo homem à luz de sua experiência concreta.

O exercício da atividade de interpretação e aplicação do Direito em um ambiente permeado por uma textualidade normativa aberta e uma linguagem de princípios, não raramente referenciados a valores, traz ao Judiciário a função ampla de intérprete destes mesmos valores, de uma moral subjacente a estes, influenciando diretamente na própria interpretação e tradução que a sociedade possui destes axiomas, quando este processo de adensamento do texto normativo desloca-se de um prévio processo de formação do texto para um processo a posteriori, realizado no âmbito de nossas Cortes Superiores, em especial no Supremo Tribunal Federal.

Neste sentido, passam as Cortes a exercer de forma mais ampla em seu processo interpretativo e de aplicação do Direito uma função que precipuamente compete aos entes legislativos, representantes democráticos do povo na eleição e tradução de valores e sua implicação com os fatos, ainda que o processo de formação do Direito se dê em todas suas esferas de aplicação e interpretação ${ }^{149}$.

\footnotetext{
${ }^{147}$ REALE, Miguel. Filosofia do Direito. 20a . ed. São Paulo: Saraiva, 2002. p.190.

${ }^{148}$ Idem, ibidem. p. 191.

${ }^{149}$ Ainda que pensemos o processo de formação do Direito como algo exercido nas diferentes esferas em que se dá seu manejo, a observação de Miguel Reale nos auxilia a compreender a gradação neste processo de tradução de valores, dentro dos diferentes níveis de produção do Direito. REALE, Miguel apud RAMOS,
} 
O preenchimento e o refinamento destas normas constitucionais, carecedores de precisão terminológica e de significado, têm-se realizado no âmbito do processo judicial, colocando-o segundo parcela da doutrina, em rota de colisão com os postulados da separação de poderes e da própria Democracia.

De um lado, fincamos os marcos de um sistema de controle de constitucionalidade cujo instrumental atingiu grau de sofisticação ímpar na história constitucional brasileira, de outro, temos uma Constituição cuja tônica é a amplitude de seu texto, a imprecisão de seus postulados, albergados em cláusulas e princípios de textura aberta, erigidos em bloco de constitucionalidade, tendo ainda, não somente esta característica, mas também a ambição de possuir regramento analítico e extenso da mais vasta gama de assuntos da agenda social, econômica e política da nação, dada a grande diversidade de temas que a permeiam, típicos de uma sociedade pluralista do final do século XX, início do século XXI.

Esta realidade se acentua sobretudo quando as Cortes competentes para o conhecimento da matéria constitucional em caráter abstrato, em nossa realidade o Supremo Tribunal Federal, exercem esta atividade no âmbito das ações constitucionais.

O Supremo Tribunal Federal em suas últimas décadas tomou contornos singulares sobretudo por força dos aspectos delineados nos tópicos anteriores ${ }^{150}$. Se de um lado, o aparato técnico processual outorgado à nossa Corte Constitucional é o ferramental que

2010 aduz que: "Não nos atemoriza em mais esta oportunidade, afirmar que a verdade está no meio-termo, na conciliação dos extremos, devendo o juiz ser considerado livre, não perante a lei e os fatos, mas sim dentro da lei, em razão dos fatos e dos fins que dão origem ao processo normativo, segundo a advertência de Radbruch de que a interpretação jurídica, visando o sentido objetivamente válido de um preceito, 'não é pura e simplesmente um pensar de novo aquilo que já foi pensado, mas, pelo contrário, um saber pensar até ofim aquilo que já começou a ser pensado por outro', observação que deve ser completada com a de que a interpretação de uma norma envolve o sentido de todo o ordenamento a que pertence". (RAMOS, Elival da Silva. Ativismo Judicial: parâmetros dogmáticos. São Paulo: Saraiva, 2010. p. 137).

${ }^{150}$ Sobre o tema, corrobora a opinião de Oscar Vilhena Vieira: "A enorme ambição do texto constitucional de 1988, somada à paulatina concentração dos Poderes na esfera da jurisdição do Supremo Tribunal Federal, ocorrida ao longo dos últimos vinte anos, aponta para uma mudança no equilíbrio do sistema de separação de poderes no Brasil. O Supremo, que a partir de 1988, já havia passado a acumular as funções de tribunal constitucional, órgão de cúpula do poder judiciário e foro especializado, no contexto de uma Constituição normativamente ambiciosa, teve seu papel político ainda mais reforçado pelas emendas de no. 3/93, e no. 45/05, bem como pelas leis no. 9.868/99 e no. 9.882/99, tornando-se uma instituição singular em termos comparativos. , seja com sua própria história, seja com a história de cortes existentes em outras democracias, mesmo as mais proeminentes." (VIEIRA, Oscar Vilhena. Supremocracia. In: Rev. Direito GV [online]. vol.4, n.2, pp. 444. 2008. ISSN 1808-2432). 
propicia mecanismos para seu avanço, sua invasão nestes campos eminentemente morais e valorativos traz este Poder ao centro deliberativo da sociedade.

Sendo esta a realidade contemporânea, cabe trazer ao estudo as principais críticas e observações da doutrina sobre esta faceta do fenômeno do ativismo judicial, para que se possa explorar a tensão existente entre este pretenso ativismo e os cânones da democracia.

Oscar Vilhena Vieira vislumbra um deslocamento aos tribunais do o debate destas questões de grande relevância no âmbito jurídico e político nacional, o que aliado às características de nossa Constituição, como já exposto à saciedade nos parágrafos anteriores, nos coloca diante da tensão aqui proposta.

\begin{abstract}
Na prática, as cortes constitucionais há muito se vêm debatendo com questões morais graves, como a pena de morte, o aborto, o significado da dignidade da pessoa humana como limitação última à constituição, a relação entre privacidade e liberdade de expressão. Constituições compromissárias, como a Brasileira, por sua vez, impõem dificuldades adicionais ao judiciário. Além da obrigação de trabalhar com normas de textura aberta, que abrigam conceitos políticos e princípios morais, os juízes são obrigados a arbitrar uma competição de valores e diretivas normativas muitas vezes contraditórias ${ }^{151}$.
\end{abstract}

A leitura do excerto extraído de artigo do professor Oscar Vilhena Vieira tem a conotação de que esta realidade, de uma Constituição de carga semântica aberta é um dado ao qual não podemos fugir, e tem certamente deslocado para o âmbito da jurisdição a discussão sobre estas ditas "questões morais graves", usando aqui a terminologia adotada pelo professor Vieira.

Esta é também a conclusão de Gustavo Zagrebelsky, em seu artigo Estado Constitucional, ao colocar o chamado direito pelos princípios não como uma escolha, mas sim como uma realidade, não desconhecendo por outro lado as dificuldades que deste dado decorrem:

Todavia, uma vez que a inscrição dos princípios nas Cartas constitucionais é direta consequência do caráter pluralista do estado constitucional, a nulificação dos princípios equivaleria nada menos que à contradição de sua promessa para instaurar um poder ordenador de uma só dimensão. Daí, a conclusão que o "direito pelos princípios" e as dificuldades que dele derivam não são, hoje, uma

\footnotetext{
${ }^{151}$ VIEIRA, Oscar Vilhena. A moralidade da Constituição e os Limites da Empreitada Interpretativa, ou entre Beethoven e Bernstein. In: SILVA, Virgilio Afonso da (org). Interpretação Constitucional. São Paulo: Malheiros Editores, 2007. p. 227-8.
} 
escolha nossa, mas uma necessidade com a qual devemos conviver, buscando a melhor convivência ${ }^{152}$.

A crítica do professor Carlos Ari Vieira Sundfeld parte da mesma constatação, mostrando todavia um viés contrário a uma certa banalização no manejo dos princípios e cláusulas abertas da Constituição ${ }^{153}$.

$\mathrm{Na}$ mesma linha do apontado pelos dois autores anteriormente citados, o ilustre administrativista aponta a dificuldade em lidar com essa nova realidade, em que pese sua imposição como um fator inexorável aos tempos atuais.

Hoje, fala-se o tempo todo em princípios no direito público brasileiro. Essa moda tem três razões principais. Indeterminações aparecem aos montes na (ainda recente e sempre mudando) Constituição de 1988 e nas novas leis e, como a fábrica de princípios lança produtos sem parar, o trabalho de absorvê-los é permanente e ruídoso. Em segundo lugar, as pessoas estão cada vez mais dispostas a levar os princípios a sério como fonte de Direito - e as dificuldades que isso propõe são enormes. Por fim, a operação de um sistema com tal índice de incerteza normativa gera muita confusão (saber se a confusão é positiva ou negativa: eis uma questão!). Não é de estranhar que os princípios esteja cada vez mais na berlinda ${ }^{154}$.

Se de um lado esta conclusão, por todo o já exposto até este ponto, parece ululante, as implicações advindas do exercício deste novo foro de tradução destes axiomas são as mais diversas e têm despertado diferentes abordagens pelos estudiosos da filosofia política e do Direito Constitucional.

\footnotetext{
${ }^{152}$ ZAGREBELSKY, Gustavo. Estado Constitucional. In: HORBACH, Carlos Bastide et al (coord.). Direito Constitucional, Estado de Direito e Democracia: Homenagem ao Prof. Manoel Gonçalves Ferreira Filho. São Paulo: Quartier Latin, 2011. p. 304.

${ }^{153}$ É fundamental a colação da constatação trazida no início de seu artigo Princípio é preguiça na qual é colocada de forma crítica e atenta a necessidade de ponderação e limites ao referido ambiente de principiologizacão do Direito. "Vive-se hoje um ambiente de geleia geral no direito público brasileiro, em que princípios vagos podem justificar qualquer decisão. O objetivo deste capítulo é opor-se a essa deterioração da qualidade do debate jurídico. O profissional do Direito, ao construir soluções para os casos, tem um dever analítico. Não bastam boas intenções, não basta intuição, não basta invocar e elogiar princípios, é preciso respeitar o espaço de cada instituição, comparar normas e opções, estudar causas e consequências, ponderar as vantagens e desvantagens. Do contrário, viveremos no mundo da arbitrariedade, não do Direito." (SUNDFELD, Carlos Ari Vieira; MACEDO JÚNIOR, Ronaldo Porto (org); BARBIERI, Catarina Helena Cortada (org). Princípio é preguiça? In: Direito e interpretação: racionalidades e instituições. São Paulo: Saraiva, 2011. p. 287)

${ }^{154}$ Idem, ibidem. p. 293.
} 
Elival da Silva Ramos traz sua crítica ao apontar a valorização de uma corrente moralista que permite à Corte, competente para dar a última palavra sobre a interpretação destas cláusulas abertas, uma atuação deletéria neste ponto.

Em sua abordagem sobre o moralismo jurídico, Elival da Silva Ramos afirma que:

\begin{abstract}
A razão disso reside no fundamentalismo axiológico que está na base do moralismo jurídico, presidindo a ideia de que há uma ordem objetiva de valores fundamentais que deve servir de modelo ao direito positivo, atuando o juiz como um autêntico sacerdote a serviço dessas diretrizes ontológicas. Para tanto, deve se valer das ambiguidades, contradições e insuficiências de que os textos normativos são permeados e, principalmente, do controle de constitucionalidade, que the permite recusar validade a atos legislativos a partir de parâmetros normativos altamente flexíveis e que se prestam a manipulações argumentativas de toda a espécie ${ }^{155}$.
\end{abstract}

De acordo com a crítica apontada na obra de referência, Ativismo Judicial: Parâmetros Dogmáticos esta amálgama entre o Direito e a Moral, sustentada inclusive pelas correntes neoconstitucionalistas como um de seus pilares, traz ao intérprete aplicador liberdade ampla em sua atuação, fator de impulsão ao ativismo judicial.

\begin{abstract}
(...) a exacerbação da importância dos princípios constitucionais, marca indelével da teorização moralista, não tem outra finalidade senão dotar o intérpreteaplicador de liberdade para, se necessário, corrigir (ou, em hipóteses extremas, até mesmo recusar validade) o direito posto, em nome de uma pretensa ordem objetiva de valores imposta pela razão (Alexy) ou pela vivência histórica de uma comunidade (Dworkin) ${ }^{156}$.
\end{abstract}

Esta exacerbação dos princípios, das cláusulas abertas, advinda da vertente moralista do Direito, tende a uma eclosão dos parâmetros normativos delimitadores da função criativa do juiz, função esta que o autor não nega, dentro de sua proposta de um positivismo reflexivo, contudo, "a identificação de limites ao órgão responsável pela tarefa de concretização, sutilmente, acaba por se deslocar de um plano exclusivamente jurídiconormativo para uma dimensão axiológica, externa ao ordenamento positivo" ${ }^{\text {157 }}$.

Dentro da análise dogmática do professor Elival da Silva Ramos, a vertente chamada de moralismo jurídico constitui-se em fator de impulsão ao ativismo judicial.

\footnotetext{
${ }^{155}$ RAMOS, Elival da Silva. Ativismo Judicial: parâmetros dogmáticos. São Paulo: Saraiva, 2010. p. 116.

${ }^{156}$ Idem, ibidem. 2010. p. 307.

${ }^{157}$ Idem, ibidem. 2010, p. 88.
} 


\begin{abstract}
A razão disso reside no fundamentalismo axiológico que está na base do moralismo jurídico, presidindo a ideia de que há uma ordem objetiva de valores fundamentais que deve servir de modelo ao direito positivo, atuando o juiz como um autêntico sacerdote a serviço dessas diretrizes ontológicas. Para tanto, deve se valer das ambiguidades, contradições e insuficiências de que os textos normativos são permeados e, principalmente, do controle de constitucionalidade, que lhe permite recusar validade a atos legislativos a partir de parâmetros normativos altamente flexíveis e que se prestam a manipulações argumentativas de toda a espécie ${ }^{158}$.
\end{abstract}

Dentro da ótica apresentada por Elival da Silva Ramos, a assunção pelo Poder Judiciário, sobretudo do controle de constitucionalidade, tem sido importante fator de impulsão do ativismo judicial, levando à violação e à perda de parâmetros claros do sistema normativo como um todo.

Na seara dos autores que trazem críticas a esta atividade dos Tribunais, é necessária a análise das críticas de Jürgen Habermas e John Hart Ely, ainda que distante da amplitude de análise que as obras dos referidos autores merecem e com o cuidado necessário para que não transportemos à experiência brasileira fatores advindos de culturas jurídicas diversas que não sejam aplicáveis ao nosso contexto.

A posição do pensador alemão e do jurista norte-americano, ainda que comportem diferenças, e, ainda que advindas de realidades constitucionais distintas, no caso de Habermas à experiência alemã do Tribunal Federal Constitucional, e em Ely, à experiência americana permeada por uma forte cultura de precedentes judiciais da common law, parecem em alguns pontos aplicar-se claramente a um contexto de certa forma universal, e por consequência à experiência brasileira.

Partindo da crítica de Habermas, algumas considerações fazem-se necessárias.

Seguindo orientação extraída da análise de Jean Paul C. Veiga da Rocha, o autor alemão formula quatro princípios sobre o Estado de Direito, o primeiro deles o da soberania popular, pelo qual "os cidadãos devem criar suas próprias leis que os vinculam, mediante um processo político democrático institucionalizado" "159, o segundo, o princípio da "ampla

\footnotetext{
${ }^{158}$ RAMOS, Elival da Silva. Ativismo Judicial: parâmetros dogmáticos. São Paulo: Saraiva, 2010. p. 135.

${ }^{159}$ ROCHA, Jean Paul C. Veiga da. Separação dos Poderes e Democracia Deliberativa. In: NOBRE, Marcos; TERRA, Ricardo. (Orgs.). Direito e Democracia: um guia de leitura de Habermas. São Paulo: Malheiros Editores, 2008. p. 181.
} 
proteção jurídica do indivíduo, por meio de um Poder Judiciário independente"160, o princípio da legalidade na administração pública, pelo qual "se garante a submissão de poder administrativo ao poder comunicativo"161 , e o último, "princípio da separação entre Estado e Sociedade" ${ }^{\prime 162}$.

No âmbito desta classificação nos desperta especial interesse a observação do segundo princípio.

Transcreveremos aqui trecho de artigo de Jean Paul C. Veiga da Rocha, o qual serve de explicação essencial ao que Habermas busca demonstrar em relação ao segundo princípio:

\begin{abstract}
Aqui, Habermas retoma a distinção entre as competências de legislar, de um lado, e de aplicar o direito de outro. A lei é produzida pelo Poder Legislativo com base em discursos de justificação (ou de fundamentação), para pautar a atuação estatal e lastrear as pretensões jurídicas dos indivíduos. O Poder Judiciário, como representante imparcial da comunidade jurídica, desenvolve, perante uma ampla esfera pública jurídica, um discurso de aplicação de normas. Justificação e aplicação, portanto, implicam distintas lógicas de argumentação que precisam ser distribuídas em dois diferentes Poderes do Estado. Complementando esse quadro, o princípio da vinculação do juiz à lei impede o Judiciário, que detém o poder de determinar a execução administrativa de suas próprias decisões, de definir o conteúdo de sua própria atuação. Habermas lembra também que o princípio da proteção jurídica, combinado com o devido processo legal, promove a segurança jurídica e a aceitação racional das decisões judiciais ${ }^{163}$.
\end{abstract}

Dentro da conceituação desenvolvida por Habermas, a função jurisdicional encontra limites à sua atuação de forma a respeitar os limites do decidido dentro do processo de justificação existente na criação do direito pelo Legislador, com base no princípio da soberania popular.

Este arquétipo aponta no sentido de uma contenção da atuação do Poder Judiciário delimitando o campo de atuação deste, implicando limites que refletem fundamentalmente na questão.

${ }^{160}$ Idem, ibidem. p. 181.

${ }^{161}$ ROCHA, Jean Paul C. Veiga da. Separação dos Poderes e Democracia Deliberativa. In: NOBRE, Marcos; TERRA, Ricardo. (Orgs.). Direito e Democracia: um guia de leitura de Habermas. São Paulo: Malheiros Editores, 2008. p. 182.

${ }^{162}$ Idem, ibidem. p. 182.

${ }^{163}$ ROCHA, Jean Paul C. Veiga da. Separação dos Poderes e Democracia Deliberativa. In: NOBRE, Marcos; TERRA, Ricardo. (Orgs.). Direito e Democracia: um guia de leitura de Habermas. São Paulo: Malheiros Editores, 2008. p. 181-2. 
Dentro da concepção habermasiana, a atuação do Poder Judiciário faz-se por meio de um discurso de aplicação de normas, de forma que não entre em rota de colisão com o discurso de justificação inerente à atividade legislativa na formação do direito ${ }^{164}$.

Dentro desta ótica, surge uma tensão latente, sobre como restaria a questão posta no presente capítulo, a atividade da Jurisdição Constitucional como intérprete e responsável em última análise pela própria definição da normatividade, pois, se a matéria-prima configura-se de característica ampla, vaga, maleável, seria o Tribunal o responsável por lapidá-la, fundindo na aplicação deste sistema de normas também a atividade de refino de seu significado.

Com base na análise da chamada jurisprudência de valores do Tribunal alemão, Habermas afirma que esta metodologia "coloca a jurisprudência constitucional num estado de legislação concorrente" ${ }^{\text {165 }}$.

Habermas refuta a ideia da atividade dos Tribunais constitucionais para além do caráter deontológico dos direitos, para a busca de fundamentações baseadas em valores nas quais se realiza uma gradação de validade das normas diante de casos concretos, o que ocorre nos juízos de ponderação ${ }^{166}$.

Ainda que se trate de realidades diversas, e o objeto de análise de Habermas se funda na chamada jurisprudência de valores, sua crítica é aplicável a outras realidades constitucionais, dentre elas a brasileira ${ }^{167}$, dentro das características hoje presentes em nossa Constituição.

\footnotetext{
${ }^{164}$ Cabe aqui transcrever a observação de Jürgen Habermas: “A prática da decisão está ligada ao direito e à lei, e a racionalidade da jurisdição depende da legitimidade do direito vigente. E esta depende, por sua vez, da racionalidade de um processo de legislação, o qual, sob condições da divisão de poderes do Estado de direito, não se encontra à disposição dos órgãos de aplicação do direito." (HABERMAS, Jürgen. Direito $e$ Democracia: entre facticidade e validade. 2. ed. Flávio Beno Siebeneichler (Trad). Rio de Janeiro: Tempo Brasileiro, 2012. p. 297. V. 1)

${ }^{165}$ HABERMAS, Jürgen. Direito e Democracia: entre facticidade e validade. 2. ed. Flávio Beno Siebeneichler (Trad). Rio de Janeiro: Tempo Brasileiro, 2012. p. 312. V. 1.

${ }^{166}$ Segundo a análise de Paulo Gustavo Gonet Branco "Habermas alinha-se com a crítica que rejeita a assimilação de normas (ou princípios normativos) a valores. Assinala que as normas possuem sentido deontológico e os valores, teleológico. As normas tem sentido de obrigação indeclinável, enquanto os valores expressam referência de agir teleológico. (BRANCO, Paulo Gustavo Gonet. Juízo de Ponderação na jurisdição constitucional. São Paulo: Saraiva, 2009. p. 73).

${ }_{167}$ Corrobora com esta possibilidade de utilização da crítica à jurisprudência de valores do Tribunal Constitucional alemão a observação dos professores Conrado Hübner Mendes e Virgílio Afonso da Silva: "Embora essa crítica tenha como alvo a jurisprudência do Tribunal Constitucional alemão, a sua importância
} 
Algumas passagens da importante obra do pensador alemão, que diz especial respeito ao âmbito jurídico, Direito e Democracia: entre facticidade e validade, nos mostram as implicações deste quadro em que a respectiva Corte Constitucional passa a trabalhar com normas de alta carga axiológica, de conteúdos que pela sua imprecisão passam a carecer de um refinamento interpretativo que passa a definir em verdade o significado destas cláusulas abertas, muitas vezes, para além dos limites hermenêuticos claros e das balizas normativas.

\begin{abstract}
Ao deixar-se conduzir pela ideia da realização de valores materiais, dados preliminarmente no direito constitucional, o tribunal constitucional transforma-se numa instância autoritária. No caso de uma colisão, todas as razões podem assumir o caráter de argumentos de colocação de objetivos, o que faz ruir a viga mestra introduzida no discurso jurídico pela compreensão deontológica de normas e princípios do direito ${ }^{168}$.
\end{abstract}

Um dos fatores trazidos pelo pensador alemão tem ligação com características do advento do Estado Social, o qual trouxe influxos à ordem jurídica de objetivos políticos fundamentados em princípios. Esta característica parece presente também em nosso contexto.

\begin{abstract}
(...) a ordem jurídica materializada do Estado Social - a qual não consiste apenas, e em primeira linha, em programas condicionais claramente delineados, pois inclui objetivos políticos e uma fundamentação em princípios - pode aparecer como um abalo, ou melhor, como uma corrupção da arquitetônica constitucional. Comparada à tese positivista da separação, a materialização do direito carrega atrás de si uma "remoralização", a qual afrouxa a ligação linear da justiça as vantagens do legislador político, na medida em que a argumentação jurídica se abre em relação a argumentos morais de princípio e a argumentos políticos visando a determinação de fins ${ }^{169}$.
\end{abstract}

A adoção destes parâmetros lassos no exercício das atividades de controle de constitucionalidade pode servir como medida para que se legitimem escolhas que não necessariamente se espelhem em critérios hermenêuticos claros ou encontrem ressonância no sistema jurídico vigente, mas sim em valores escolhidos ad nutum. Habermas afirma

pode ser expandida para a jurisdição constitucional de outros países. A importância para o caso brasileiro é nítida, já que a jurisprudência do Supremo Tribunal Federal cada vez mais lança mão de argumentos de valores ou princípios criticados por Habermas e, com frequência rapidamente crescente, recorre ao sopesamento ou à ponderação como forma de aplicação do direito.” (MENDES, Conrado Hübner; SILVA, Virgílio Afonso da. Habermas e a Jurisdição Constitucional. In: NOBRE, Marcos; TERRA, Ricardo. (Orgs.). Direito e Democracia: um guia de leitura de Habermas. São Paulo: Malheiros Editores, 2008.).

${ }^{168}$ HABERMAS, Jürgen. Direito e Democracia: entre facticidade e validade. 2. ed. Flávio Beno Siebeneichler (Trad). Rio de Janeiro: Tempo Brasileiro, 2010. p. 312. V. 1. p. 320-1.

${ }^{169}$ Idem, ibidem. p. 305-6. 
que "na medida em que um tribunal constitucional adota a doutrina da ordem de valores e a toma como base de sua prática de decisão, cresce o perigo dos juízos irracionais, porque, neste caso, os argumentos funcionalistas prevalecem sobre os normativos" ${ }^{\text {"170 }}$.

Esta nova realidade constitucional traz um ponto de dificuldade na operacionalização do direito, alterando características ínsitas ao Direito, como a segurança jurídica, a previsibilidade no agir diante do Direito, alterando a própria coerência do sistema normativo, quando este passa a ser maleável e sujeito à ampla tradução por parte dos Tribunais.

É certo que a Constituição deve espelhar a realidade social da qual emerge, sendo também certo que a realidade social da atualidade mostra-se fluída, plural, refletindo estas características na Constituição, contudo, também é notável a dificuldade que esta realidade traz e a problemática que dela decorre.

Sobre isto, verifica-se na crítica de Habermas a quebra de um caráter binário, deontológico, do Direito.

\begin{abstract}
Segundo Habermas, tanto a "jurisprudência dos valores" do Tribunal Constitucional alemão quanto a teria dos princípios, de Robert Alexy, teriam como consequência aquilo que chama de perda do caráter deontológico das normas de direitos fundamentais, já que os valores (e os princípios), ao contrário do que ocorre com as normas jurídicas, possuem um caráter teleológico (DD I: 330). Com isso, o sistema jurídico perde uma das características principais, que, segundo Habermas, seria a "codificação binária". Assim, ao invés de uma racionalidade baseada na diáde válido/invalido, o recurso a valores (ou a princípios) implicaria uma racionalidade estranha ao mundo jurídico, baseada em uma "codificação gradual", ancorada em relações de precedência. Isso porque valores não estipulam deveres ou direitos definitivos aos seus destinatários, mas apenas uma relação de precedência entre si (DD I: 316 ). Em vista disso, valores não teriam a vinculação absoluta de uma obrigação universal e incondiciona $1^{171}$.
\end{abstract}

A crítica do autor não deve ser vista de forma simplista, somente sob uma possível quebra deste caráter binário, deontológico do Direito: a crítica faz-se mormente quando verificada a utilização do chamado sopesamento, critério utilizado na jurisprudência alemã e também largamente na jurisprudência brasileira.

\footnotetext{
${ }^{170}$ HABERMAS, Jürgen. Direito e Democracia: entre facticidade e validade. 2. ed. Flávio Beno Siebeneichler (Trad). Rio de Janeiro: Tempo Brasileiro, 2010. p. 312. V. 1. p. 321.

${ }^{171}$ MENDES, Conrado Hübner; SILVA, Virgílio Afonso da. Habermas e a Jurisdição Constitucional. In: NOBRE, Marcos; TERRA, Ricardo. (Orgs.). Direito e Democracia: um guia de leitura de Habermas. São Paulo: Malheiros Editores, 2008. p. 210.
} 
É importante a transcrição abaixo, da lavra dos professores Virgílio Afonso da Silva e Conrado Hübner Mendes:

\begin{abstract}
Dois seriam os principais problemas desse sopesamento: em primeiro lugar, haveria o perigo de que o seu caráter teleológico e orientado pelo caso concreto pudesse levar ao sacrifício de direitos fundamentais, caso a caso, em favor de objetivos coletivos; além disso, o sopesamento entre valores ou entre princípios não seria um procedimento baseado em critérios racionais e, por isso, "seria realizado ou de forma arbitrária ou irrefletida" (DD I: 321-322) ${ }^{172}$.
\end{abstract}

Ainda segundo a análise dos professores Virgílio Afonso da Silva e Conrado Hübner Mendes, Habermas vê a ampla utilização dos critérios de ponderação como uma forma atrelada a subjetivismos do julgador, e nisto se afasta do caráter sistêmico, imperativo do Direito, "substitui-se a decisão do legislador, que, ao criar uma lei, expressa a sua forma particular de interpretar a constituição, pela opinião alternativa do juiz sobre o mesmo problema" $" 173$.

A crítica do pensador alemão toca em pontos fundamentais que surgem quando vislumbramos a atuação "ativista” do Poder Judiciário ao manejar estas cláusulas abertas, princípios e valores, e com base nesta atividade, conformar todo o sistema normativo, preenchendo o próprio conteúdo do Direito vigente em sua atividade de intérprete da Constituição.

Partilhando de parte da crítica sustentada por Habermas, John Hart Ely, com base na experiência constitucional norte-americana sustenta um modelo de controle de constitucionalidade procedimental, em detrimento de uma análise substancial da Constituição, reservando a realização desta tarefa de tradução dos valores morais da sociedade ao âmbito da política.

A construção de uma teoria procedimental sobre o controle de constitucionalidade dá-se pela descrença do autor no exercício desta tarefa decisória sobre questões fundamentais da sociedade no âmbito da Suprema Corte, por razões diversas, dentre elas o caráter antidemocrático não somente da função judicial, mas do fato da retirada desta

172 MENDES, Conrado Hübner; SILVA, Virgílio Afonso da. Habermas e a Jurisdição Constitucional. In: NOBRE, Marcos; TERRA, Ricardo. (Orgs.). Direito e Democracia: um guia de leitura de Habermas. São Paulo: Malheiros Editores, 2008. p. 210.

${ }^{173}$ Idem, ibidem. p. 213. 
possibilidade do âmbito do debate público com sua transferência ao âmbito restrito do processo judicial, ao alvitre de uma ínfima parcela de justices, ou em nosso caso, de ministros componentes de nossa Corte superior.

\begin{abstract}
A experiência nos diz que, na verdade, haverá sim uma distorção sistemática na escolha de valores fundamentais pelos juízes, uma distorção que privilegia (o que, aliás, não surpreende) os valores dos profissionais liberais da alta classe média, da qual provém a maioria dos juristas, dos juízes e também dos filósofos. As pessoas costumam achar que o que é importante para elas é importante para todos, e nós não somos exceção ${ }^{174}$.
\end{abstract}

Ely analisa alguns pontos sustentados pela doutrina americana, os quais por força do enfoque do presente trabalho não serão aqui esmiuçados: a chamada teoria dos princípios neutros, pela qual as decisões da Corte deveriam pautar-se em um princípio a ser utilizado em decisões posteriores, o que manteria seu grau de coerência e certeza, argumentos baseados em uma suposta primazia do Poder Judiciário para realização de raciocínios sobre questões fundamentais e morais, pois não estaria sujeito às pressões a que se submete o Poder Legislativo, ao recurso à tradição, muito difundido na experiência americana, talvez menos presente na cultura jurídica brasileira, e, a tese sobre valores partilhados pelo consenso.

A análise destas questões não afasta o autor de uma conclusão no sentido de que estas questões substantivas da Constituição devem permanecer e resolver-se no âmbito do debate político democrático, cabendo à Corte uma função procedimental, de forma a desobstruir os entraves na participação política.

\begin{abstract}
Mais uma vez aprendemos que é possível raciocinar sobre as questões morais, mas debater questões éticas não é a mesma coisa que descobrir uma verdade ética absoluta. Então, voltamos ao ponto inicial: nossa sociedade não aceita a noção de um conjunto de princípios morais objetivamente válidos e passíveis de ser descobertos; pelo menos, não aceita um conjunto que sirva para derrubar as decisões de nossos representantes eleitos - e tem razão de não aceitá-lo ${ }^{175}$.
\end{abstract}

A proteção das Cortes superiores far-se-ia por meio da desobstrução dos canais de participação ao processo político democrático, preservando cláusulas procedimentais necessárias a propiciar um ambiente igualitário no processo de participação política.

\footnotetext{
${ }^{174}$ ELY, John Hart. Democracia e Desconfiança: uma teoria do controle judicial de constitucionalidade. Juliana Lemos (Trad). São Paulo: WMF Martins Fontes, 2010. p. 78.

${ }^{175}$ Idem, ibidem. p. 72.
} 
Jürgen Habermas traz interessante observação sobre a concepção de Ely, na obra já citada nos parágrafos anteriores, a qual vale ser transcrita.

\begin{abstract}
A concepção cética desenvolvida por J. H. Ely procura aliviar a jurisprudência da orientação por princípios jurídicos de proveniência moral ou ética em geral. Ely parte da ideia de que a constituição americana regula, em primeira linha, problemas de organização e de procedimento, não sendo talhada para a distinção e implementação de valores fundamentais. No seu entender, a substância da constituição não reside em regulamentos materiais e sim formais (tais como, equal protection ou due process of law) ${ }^{176}$.
\end{abstract}

Segundo Habermas, ao analisar a visão de Ely, "o tribunal tem que tomar precauções para que permaneçam intactos os "canais" para o processo inclusivo de formação da opinião e da vontade, através do qual uma comunidade jurídica democrática se auto-organiza" 177 .

A análise do autor norte-americano é focada em especial na experiência da Suprema Corte norte americana, da qual foi auxiliar na era Warren, razão pela qual deve-se fazer a ressalva e o recorte necessário à sua crítica para sua transposição ou comparação ao nosso contexto, mormente pelo fato de que o jurista norte-americano faz uma análise da Constituição de seu país como de viés procedimental, de caráter constitutivo ${ }^{178}$, e não como uma carta de direitos substantivos ${ }^{179}$, o que torna possível e mais clara sua construção sobre o controle de constitucionalidade procedimental.

Contudo, a crítica sobre a questão das Cortes Constitucionais como intérpretes e tradutoras de questões valorativas e abertas parece sim, na mesma linha do apontado por Jürgen Habermas ${ }^{180}$, aplicável à nossa realidade, uma vez que ainda que com tons diferentes, mostram-se como realidades análogas.

${ }^{176}$ HABERMAS, Jürgen. Direito e Democracia: entre facticidade e validade. 2. ed. Flávio Beno Siebeneichler (Trad). Rio de Janeiro: Tempo Brasileiro, 2012. p. 312. V. 1. p. 326.

${ }_{177}$ Idem, ibidem. p. 327.

${ }^{178}$ ELY, John Hart. Democracia e Desconfiança: uma teoria do controle judicial de constitucionalidade. Juliana Lemos (Trad). São Paulo: WMF Martins Fontes, 2010. p. 134.

${ }^{179}$ Neste ponto é importante trazer a doutrina de Daniel Sarmento, onde o constitucionalista justamente coloca a Constituição brasileira como de viés diverso daquele apontado por Hart Ely: "É uma Constituição, por isso mesmo, pródiga na consagração de valores substantivos. Ela não se contenta em traçar as regras do jogo democrático, nem se limita a estabelecer as condições materiais necessárias para se tornar a democracia possível - embora também o faça. Ela não é, definitivamente, uma Constituição do tipo procedimental, já que acolhe valores materiais como dignidade da pessoa humana e solidariedade social, tornando-os de observância compulsória no âmbito do Estado e da sociedade". (SARMENTO, Daniel. Ubiquidade constitucional: os dois lados da moeda. In: SARMENTO, Daniel. Livres e iguais: estudos de direito constitucional. Rio de Janeiro: Lumen Juris, 2006. p. 179).

${ }^{180}$ Habermas sintetiza de forma precisa esta parcela da crítica de Ely que se amolda tanto a suas preocupações, como nas modestas formulações deste trabalho, cabendo transcrever novamente o escólio do 
Partindo também da realidade alemã, vale trazer à colação a crítica da professora da Universidade Johan Wolfgang Goethe, de Frankfurt, Ingeborg Maus, no conhecido artigo Judiciário como superego da sociedade: o papel da atividade jurisdicional na "sociedade órfã.

O cerne de suas observações funda-se na assunção pelo Poder Judiciário de uma figura paterna, o superego de uma sociedade, ao definir o alcance e traduzir os valores morais desta sociedade.

A professora da Universidade de Frankfurt inicia sua constatação ao elaborar um diálogo com o pensador da Escola de Frankfurt, Herbert Marcuse, cujos trabalhos na década de sessenta apontavam a perda do objeto de psicanálise, com a dissolução da figura paterna na formação do ego, com a diminuição da integração social no âmbito pessoal.

\begin{abstract}
À primeira vista, o crescimento no século XX do "Terceiro Poder", no qual se reconhecem todas as características tradicionais da imagem do pai, parece oporse a essa análise de Marcuse. Não se trata simplesmente da ampliação objetiva das funções do Judiciário, com o aumento do poder da interpretação, a crescente disposição para litigar ou, em especial, a consolidação do controle jurisdicional sobre o legislador, principalmente no continente europeu após as duas guerras mundiais . Acompanha essa evolução uma representação da Justiça por parte da população que ganha contornos de veneração religiosa ${ }^{181}$.
\end{abstract}

A autora aponta um hipostasiação do Poder Judiciário e do papel da Constituição, a qual pode ser identificada em nossa experiência dentre as características assumidas pelo Poder Judiciário, em especial o Supremo Tribunal Federal, e pelas características de nossa carta de direitos.

\begin{abstract}
A apropriação da persecução de interesses sociais, de processos de formação da vontade política e dos discursos morais por parte da mais alta corte é alcançada mediante uma profunda transformação do conceito de Constituição: esta deixa de ser compreendida - tal qual nos tempos da fundamentação racional-jusnatu-
\end{abstract}

pensador alemão: “Apoiado em tal compreensão procedimentalista da constituição, Ely deseja fundamentar "judicial self-restraint". Em sua opinião, o tribunal constitucional só pode conservar sua imparcialidade, se resistir à tentação de preencher seu espaço de interpretação com juízos de valores morais. O ceticismo de Ely discorda, não somente de uma jurisprudência de valores, como também de uma interpretação dirigida por princípios, no sentido da interpretação construtiva de Dworkin". (HABERMAS, Jürgen. Direito e Democracia: entre facticidade e validade. 2. ed. Flávio Beno Siebeneichler (Trad). Rio de Janeiro: Tempo Brasileiro, 2012. p. 328. V. 1).

${ }^{181}$ MAUS, Ingeborg. Judiciário como superego da sociedade: o papel da atividade jurisdicional na “sociedade órfã". In: Novos Estudos CEBRAP, n. 58, p. 185, nov. 2000. 
ralista da democracia - como documento da institucionalização de garantias fundamentais das esferas de liberdade nos processos políticos e sociais, tornando-se um texto fundamental a partir do qual, a exemplo da Bíblia e do Corão, os sábios deduziriam diretamente todos os valores e comportamentos corretos. O TFC, em muitos de seus votos de maioria, pratica uma "teologia constitucional $^{182}$.

Tal qual apontado nos parágrafos anteriores, a evolução da Constituição para uma carta composta por cláusulas abertas, cujos direitos são exprimidos por cláusulas de alta carga valorativa, moral, concedeu ao Poder Judiciário a possibilidade de imiscuir-se no papel de tradutor das principais questões e valores da sociedade, tomando o espaço do debate político, fator de impulsão do chamado ativismo judicial.

A constatação efetuada na realidade alemã parece se amoldar com certa clareza à nossa realidade constitucional. Segundo Maus:

\footnotetext{
A transformação da Constituição em uma "ordem de valores" confere às determinações constitucionais individuais (por meio da "abertura" de suas formulações) uma imprecisão tal que é capaz de suprir e ampliar voluntaristicamente os princípios constitucionais positivados ${ }^{183}$.
}

A leitura aponta a preocupação, comum às críticas até aqui expostas, de que este contexto dê espaço a voluntarismos e decisões desprovidas de lastro hermenêutico e normativo, o que desnatura a função do direito como um sistema normativo e coloca o Poder Judiciário, mormente pela natureza das questões que têm sido discutidas e pelo alcance de suas decisões, nos remetendo aqui às observações já feitas sobre a evolução de nossos sistema de controle de constitucionalidade, em uma posição ativista, conformando os próprios rumos da sociedade para além das decisões fundamentais tomadas pelo Poder Legislativo ou mesmo pelo Constituinte originário.

Esta preocupação do pensamento jurídico com uma revalorização de uma doutrina de valores, ou como um moralização do Direito e da Constituição, como já apontado na crítica de Elival da Silva Ramos, há tempos encontram ressonância da doutrina internacional.

${ }^{182}$ MAUS, Ingeborg. Judiciário como superego da sociedade: o papel da atividade jurisdicional na "sociedade órfâ". In: Novos Estudos CEBRAP, n. 58, p. 192, nov. 2000.

${ }^{183}$ Idem, ibidem. p. 200. 
Carl Schmitt, em artigo traduzido para diversos idiomas - em português: A Tirania dos Valores - apontava uma preocupação com um revalorização da teoria dos valores de Max Scheler, cuja razão provavelmente se encontraria na resposta ã crise nihilista do século XIX, e sua utilização na filosofia política, sobretudo por sua penetração na jurisprudência dos tribunais superiores.

O constitucionalista alemão já apontava que “con la invasión de 'valores'se provocó, en toda su agudeza, el problema de la disolución de conceptos y métodos jurídicos"184.

A tirania dos valores abordada por Schmitt reside na condição subjetiva da lógica dos valores e dos riscos que sua lógica interpretativa traz em si mesma. Nas palavras do constitucionalista, "La libertad puramente subjetiva de establecer valores, sin embargo, conduce a una lucha eterna de valores e ideologias, a una guerra de todos contra todos $" 185$.

Sua crítica aguda à utilização de uma jurisprudência fundada em valores coloca a questão na mesma seara da crítica daqueles que enxergam o risco de decisões judiciais pautadas em critérios subjetivos, em que os valores se impõem, dada sua própria natureza, o que não seria diferente quando transportada ao âmbito da política ou de uma Corte Constitucional.

\begin{abstract}
Nos enfrentamos, pues, con la lógica inmanente del pensamento de valores a la cual nadie puede escapar. Subjetivo u objetivo, formal o material, en cuanto aparece el valor se hace inevitable un cambio especifico de pensamento. Este cambio, hay que decirlo, es la consecuencia fatal de um pensar en valores. Porque lo especifico del valores estriba en que solamente vale y no es. La ponencia, por consiguiente, no significa nada si no se impone; la validez tiene que ser continuamente actualizada, es decir, hacerse valer, si no se disuelve en vana apariencia. Quien disse valor quiere haver valer e imponer. Las virtudes se ejercen, las normas se aplican, la órdenes se cumplen; pero los valores se establecen y se imponen. Quien disse que valen, sin que nadie los haga valer, quier engañar ${ }^{186}$.
\end{abstract}

Se de um lado, as críticas dos autores supracitados constituem-se em uma clara preocupação com a ausência de critérios claros neste processo de tradução dos valores,

\footnotetext{
${ }^{184}$ SCHMITT, Carl. La Tirania de los Valores. Anima Schmitt de Otero (Trad.). In: Revista de Estudios Politicos, Madrid, 115, p. 67, Enero-Frebrero/1961.

${ }^{185}$ Idem, ibidem. p. 70.

${ }^{186}$ SCHMITT, Carl. La Tirania de los Valores. Anima Schmitt de Otero (Trad.). In: Revista de Estudios Políticos, Madrid, 115, p. 71, Enero-Frebrero/1961.
} 
com a quebra do caráter deontológico do sistema normativo, e com a violação ao postulado democrático, parcela da doutrina enxerga o fenômeno sem as ressalvas apontadas, mas sim como algo a festejar.

Quando observados os apontamentos realizados no capítulo destinado à abordagem da visão neoconstitucionalista sobre a atuação ativista do poder Judiciário, pode-se perceber que "moralização do Direito e da Constituição", aliadas ao protagonismo Judiciário pregado por esta parcela do pensamento jurídico, são vistas como uma necessidade dos novos tempos, dentro da proposta deste viés do pensamento jurídico-constitucional.

Eduardo Cambi enxerga nesta nova relação do Direito com a Moral uma condição de validade do direito positivo enquanto espelhem estes valores morais.

\begin{abstract}
Os princípios e valores, contidos na Constituição (especialmente a dignidade da pessoa humana, a solidariedade social,a liberdade e a igualdade) abriram uma via de penetração moral no direito positivo. Logo, direitos fundamentais, concebidos como princípios, são válidos enquanto correspondem às exigências morais sentidas em um período específico, não podendo ser meramente abolidos (são cláusulas pétreas, conforme o art. $\left.60, \S 4^{\circ}, \mathrm{IV}, \mathrm{da} \mathrm{CF}\right)^{187}$.
\end{abstract}

A narrativa do autor "neoconstitucionalista" pugna ao mesmo tempo por uma certa forma de contenção à atividade judicial, ao afirmar que "a alternativa ao passivismo judiciario não é o ativismo tosco, pelo qual o juiz estaria livre para julgar conforme o seu senso de justiça."188, e por outro lado, o coloca como agente de transformação social à luz da realidade social, afirmando ser "função judicial promover a paz social, pela mediação entre grupos e interesses, entre o direito e a justiça" 189 , sendo uma atividade "transformadora guiada pela atividade intersocial de produção responsável de projetos de justiça social inclusiva (pró-atividade na tutela dos interesses sociais relevantes) ${ }^{\prime 190}$.

A narrativa de Gustavo Zagrebelsky coloca a questão na rota dos trabalhos dos juízes, afirmando que na linguagem dos princípios constitucionais subjaz uma discussão moral.

\footnotetext{
${ }^{187}$ CAMBI, Eduardo. Neoconstitucionalismo e neoprocessualismo: direitos fundamentais, políticas públicas e protagonismo judiciário. São Paulo: Revista dos Tribunais, 2009. p. 134.

${ }^{188}$ Idem, ibidem. p. 247.

${ }^{189}$ Idem, ibidem. p. 247.

${ }^{190}$ Idem, ibidem. p. 245-6.
} 


\begin{abstract}
A invocação de um princípio escrito na constituição é frequentemente apenas o modo para abrir uma discussão que se coloca em outro lugar. Nos autos dos juízes constitucionais encontram lugar não apenas as opiniões dos juristas, mas também as discussões entre filósofos morais. Se a natureza real dos problemas nem sempre emerge com clareza, é apenas porque fica ocultada - poder-se-ia dizer: por pudor positivista - atrás de argumentos jurídicos "técnicos", de fachada ${ }^{191}$
\end{abstract}

Fica claro que na visão destes autores, ainda que haja uma certa preocupação com as dificuldades que emergem desta nova realidade constitucional de diversos países, como o Brasil, a atuação do Poder Judiciário como médium de um sistema normativo que para estes autores, ultrapassa as fronteira do texto normativo para adentar nos campos da moral, é um dado visto de forma positiva e necessária ao implemento deste projeto neoconstitucionalista.

Trazendo o já mencionado artigo de José Carlos Francisco, (Neo) Constitucionalismo na Pós-Modernidade: Princípios Fundamentais e Justiça no Caso Concreto, o autor deixa claro que, na contramão das críticas apontadas nos parágrafos anteriores, o movimento neoconstitucionalista empenha-se pela absorção desta moralidade, de uma jurisprudência de valores ao exercício da função judicial.

\begin{abstract}
O maior espaço deixado pelo aumento do grau de abstração dos princípios constitucionais positivados aumenta o grau de discricionariedade do operador do Direito no processo interpretativo e de escolha das soluções para os problemas apresentados, e é justamente a via pela qual, de modo consciente ou inconsciente (intuitivo), passam valores éticos e morais mesmo para o intérprete com postura positivista. Por isso, acreditamos que o neoconstitucionalismo pode ser apresentado como oposição ao positivismo jurídico puro quando há claro reconhecimento do fato de valores morais e até mesmo elementos políticos adentrarem no campo normativo em razão da grande abertura semântica permitida pelos princípios, mas não a todas as formas de manifestação do positivismo jurídico, especialmente o positivismo inclusivo ou moderado ${ }^{192}$.
\end{abstract}

O discurso neoconstitucionalista, seja de forma explícita, seja de forma mitigada, adota orientação de que o protagonismo judiciário é uma opção, a tábua de salvação para o implemento dos valores erigidos na Constituição de 1988, substituindo em grande parte a atividade executiva na realização dos programas derivados de nossa Carta, e o poder

${ }^{191}$ ZAGREBELSKY, Gustavo. Estado Constitucional. In: HORBACH, Carlos Bastide et al (coord.). Direito Constitucional, Estado de Direito e Democracia: Homenagem ao Prof. Manoel Gonçalves Ferreira Filho.

São Paulo: Quartier Latin, 2011. p. 303.

${ }^{192}$ FRANCISCO, José Carlos. (Neo) Constitucionalismo na Pós-Modernidade: Princípios Fundamentais e Justiça no Caso Concreto. In: FRANCISCO, José Carlos (Coord. e coautor). Neoconstitucionalismo e atividade jurisdicional: do passivismo ao ativismo judicial. Belo Horizonte: Del Rey, 2012. p. 65 . 
legislativo, ao atrair ao locus do processo judicial, a atividade de construção desta normatividade derivada desta cláusulas e princípios de textura ampla.

A atividade judicial, segundo o pensamento do autor, na ótica neoconstitucionalista, "procura uma transição para uma atividade mais ativa marcada pela jurisprudência de valores"193.

Os apontamentos feitos por estes autores nos remetem exatamente às críticas levantadas no início do presente capítulo.

Há uma opção clara nesta parcela do pensamento jurídico por um ativismo judicial, tomando como premissa esta invasão de conteúdos abertos nos espaços do Direito e da interpretação constitucional, sem que muitas vezes se questionem os riscos e questões tormentosas que advêm desta atividade ativista, os quais parecem bem percebidos pelas críticas postas anteriormente.

Se de um lado, o fenômeno de fusão entre conteúdos morais, valores e princípios de larga abertura interpretativa ao direito positivo, em especial, à Constituição, mostra-se uma realidade, de outro lado, para aqueles que o enxergam de forma festejada, não trazem uma equação exata ou algum meio de contenção eficaz para que não se comute a atividade judicial em uma atividade hipertrofiada, que atue de forma concorrente ao legislador positivo e mesmo ao Poder Constituinte, uma vez que dada a vagueza dos textos constitucionais, estes acabam sendo lapidados e construídos pelo próprio Poder Judiciário, dentro de um quadro de protagonismo judiciário e de incremento e expansão do controle abstrato de normas.

Os excessos de uma metodologia aberta pregada pela vertente neoconstitucionalista, ou mesmo por aqueles que sem trazer a si os prefixos "neo" positivista ou "neo" constitucionalistas encampam um discurso de protagonismo judiciário, de abertura ampla dos parâmetros de controle e de larga utilização dos princípios, com métodos de trabalho calcados na utilização excessiva de critérios de ponderação, tendem a nos colocar em um

${ }^{193}$ FRANCISCO, José Carlos. (Neo) Constitucionalismo na Pós-Modernidade: Princípios Fundamentais e Justiça no Caso Concreto. In: FRANCISCO, José Carlos (Coord. e coautor). Neoconstitucionalismo e atividade jurisdicional: do passivismo ao ativismo judicial. Belo Horizonte: Del Rey, 2012. p. 66. 
ambiente de desvalorização do princípio democrático tal qual conhecido desde o constitucionalismo moderno, pela transferência ao Poder Judiciário da função de tradutor de toda uma gama de questões as quais, em um raciocínio a priori, deveriam ser lapidadas e maturadas com a participação social, ainda que sob a forma de uma democracia representativa.

As leituras até aqui realizadas fecham um círculo em que nos parece difícil refutar a conclusão de que o Poder Judiciário assume na atualidade função central e de proeminência diante dos demais poderes instituídos, na qual o mesmo funde-se como intérprete, criador e aplicador do Direito, ainda que sobre esta conclusão pairem as fundadas críticas e objeções abordadas neste capítulo, bem como aquelas que serão aduzidas no capítulo destinado ao confrontamento da questão com a democracia.

Este "círculo" fecha-se quando temos de um lado um sistema de controle de constitucionalidade cujas características permitiram um avanço substancial da atividade das Cortes Superiores, sobretudo, em nossa realidade, do Supremo Tribunal Federal; de outro lado, um movimento de moralização do Direito, o alargamento dos parâmetros do texto constitucional e por conseguinte, a ampliação e fluidez do bloco de constitucionalidade; por último, a disseminação de uma doutrina que tem fortalecido os argumentos a favor desse protagonismo judiciário e da valorização de uma hermenêutica tão fluída quanto o conteúdo normativo de nossos preceitos constitucionais, abertos, vagos, nas palavras de Lênio Streck, um ambiente de "panprincipiologismo"194.

Esta faceta do ativismo judicial tem se mostrado presente de forma crescente em diversas realidade mundiais, bem como, na agenda de nosso Supremo Tribunal Federal.

Para que não fiquemos apenas no plano teórico, passaremos a dar um pequeno exemplo deste quadro na atuação do Supremo Tribunal Federal.

Não se registra aqui a pretensão de uma exaustiva análise de casos, mas sim do registro exemplificativo de como a questão tem se colocado no bojo da fundamentação das decisões proferidas pelo Supremo Tribunal Federal.

\footnotetext{
${ }^{194}$ STRECK, Lenio Luiz. Verdade e Consenso: constituição, hermenêutica e teorias discursivas. $4^{\mathrm{a}}$. ed. São Paulo: Saraiva, 2011. p. 50.
} 
A constatação do alargamento da função judicial apontada ao longo deste trabalho, em especial sobre a atuação do Supremo Tribunal Federal não se mostra uma tarefa difícil.

$\mathrm{O}$ atual momento de nosso quadro político social e a intensa exposição midiática comprovam o fato de que o Supremo Tribunal Federal passou a ocupar posição central na agenda política e social do país.

Os julgamentos realizados pelo Supremo Tribunal Federal, mormente sobre os casos em que se debatem questões fundamentais de ampla penetração no tecido social, assumem importância central nas mídias televisas, impressas e sociais, o que se percebe sem maiores dificuldades: há um protagonismo do debate travado nestas causas, perante o Poder Judiciário com relação à estas grandes pautas de maior repercussão social.

Este alargamento da função judicial, como já exposto, se diz não somente com relação à absorção de uma vasta agenda de questões analisadas nas últimas décadas pelo Supremo ${ }^{195}$, mas também e principalmente à absorção de um discurso e de uma metodologia de trabalho em que os conteúdos morais, uma excessiva utilização de princípios na fundamentação de seus julgamentos, têm se tornado a tônica na sua jurisprudência.

Para ilustrarmos o já exposto no decorrer deste capítulo, começamos com a transcrição de trechos do discurso do Decano do Supremo Tribunal Federal, Ministro Celso de Mello, proferido em nome do Supremo Tribunal Federal na sessão de posse do Ministro Carlos Ayres Britto.

Práticas de ativismo judicial, embora moderadamente desempenhadas pela Corte Suprema em momentos excepcionais, tornam-se uma necessidade institucional, quando os órgãos do Poder Público se omitem ou retardam, excessivamente, o cumprimento de obrigações a que estão sujeitos, ainda mais se se tiver presente que o Poder Judiciário, tratando-se de comportamentos estatais ofensivos à Constituição, não pode se reduzir a uma posição de pura passividade ${ }^{196}$.

\footnotetext{
${ }^{195}$ Sobre esta ampla agenda enfrentada pelo Supremo Tribunal Federal, Oscar Vilhena Vieira traz um rol que exemplifica e demonstra, em suas palavras, "que tudo no Brasil parece exigir uma 'última palavra 'do Supremo Tribunal Federal. (VIEIRA, Oscar Vilhena. Supremocracia. In: Rev. direito GV [online]. vol.4, n.2, pp. 451. 2008. ISSN 1808-2432.

${ }^{196}$ DISCURSO proferido pelo Ministro Celso De Mello, em nome no Supremo Tribunal Federal, na solenidade de posse do Ministro Carlos Ayres Britto Na Presidência Da Suprema Corte Do Brasil, em 19/04/2012. Disponível em <http://www.stf.jus.br/arquivo/cms/noticiaNoticiaStf/anexo/discursoCM.pdf>. Acesso em 20/11/2013.
} 
Referido trecho do discurso proferido pelo Ministro Celso tem sido citado com frequência em artigos e mesmo notícias veiculadas sobre a questão.

Diversos são os casos em que o Supremo Tribunal Federal tem se amparado em uma fundamentação permeada de conceitos amplos, princípios os mais diversos, cabendo inclusive um estudo de forma a elencar a diversidade de princípios citados nos julgados proferidos nos últimos anos por nossa Corte suprema, ou mesmo trazendo uma fundamentação aberta sobre os conceitos embutidos em nosso bloco de constitucionalidade.

Primeiramente, cabe observar trechos das fundamentação presente no voto do ministro Gilmar Mendes na ADI 3.150, o chamado caso das pesquisas com células-tronco.

A leitura das palavras do Ministro Gilmar Mendes revelam neste caso de grande repercussão, um dos maiores da história do Supremo Tribunal Federal, justamente aquilo que foi apontado no capítulo anterior, a assunção pelo Poder Judiciário do espaço deliberativo para questões que extrapolam o âmbito jurídico, adentrando a senda das questões morais, éticas, religiosas, da tormentosa tarefa que a priori jamais teria lugar no âmbito do exercício da jurisdição, segundo os postulados das teorias institucionais das revoluções liberais, ou mesmo segundo as lições dos juristas do início do século XX, citados em capítulos anteriores.

Passemos a leitura dos trechos do voto ${ }^{197}$.

O julgamento desta ADI $\mathrm{n}^{\circ} 3.510$, dedicadamente conduzido pelo Ministro Carlos Britto, constitui uma eloqüente demonstração de que a Jurisdição Constitucional não pode tergiversar diante de assuntos polêmicos envolvidos pelo debate entre religião e ciência.

É em momentos como este que podemos perceber, despidos de qualquer dúvida relevante, que a aparente onipotência ou o caráter contra-majoritário do Tribunal Constitucional em face do legislador democrático não pode configurar subterfúgio para restringir as competências da Jurisdição na resolução de questões socialmente relevantes e axiologicamente carregadas de valores fundamentalmente contrapostos.

${ }^{197}$ BRASIL. Supremo Tribunal Federal. ADI no 3510, Plenário do Supremo Tribunal Federal. Voto do Ministro Gilmar Mendes. Brasília, DF, 29 de maio de 2008. Disponível em: $<$ http://www.stf.jus.br/arquivo/cms/noticiaNoticiaStf/anexo/ADI3510GM.pdf>. Acesso em 22/11/13. 
Delimitar o âmbito de proteção do direito fundamental à vida e à dignidade humana e decidir questões relacionadas ao aborto, à eutanásia e à utilização de embriões humanos para fins de pesquisa e terapia são, de fato, tarefas que transcendem os limites do jurídico e envolvem argumentos de moral, política e religião que vêm sendo debatidos há séculos sem que se chegue a um consenso mínimo sobre uma resposta supostamente correta para todos.

Ainda nas palavras do Ministro Gilmar Mendes:

\begin{abstract}
O Supremo Tribunal Federal demonstra, com este julgamento, que pode, sim, ser uma Casa do povo, tal qual o parlamento. Um lugar onde os diversos anseios sociais e o pluralismo político, ético e religioso encontram guarida nos debates procedimental e argumentativamente organizados em normas previamente estabelecidas. As audiências públicas, nas quais são ouvidos os expertos sobre a matéria em debate, a intervenção dos amici curiae, com suas contribuições jurídica e socialmente relevantes, assim como a intervenção do Ministério Público, como representante de toda a sociedade perante o Tribunal, e das advocacias pública e privada, na defesa de seus interesses, fazem desta Corte também um espaço democrático. Um espaço aberto à reflexão e à argumentação jurídica e moral, com ampla repercussão na coletividade e nas instituições democráticas.
\end{abstract}

O teor do voto do ministro Gilmar Mendes torna desnecessárias maiores digressões.

O discurso subjacente ao voto do ministro revela uma penetração em espaços outrora reservados ao jogo democrático, com uma linguagem própria do espaço deliberativo, além da linguagem jurídica, ao menos à descendente de uma dogmática positivista clássica, avocando inclusive qualidade de espaço democrático à Corte.

A citação do referido julgamento, mesmo que de uma forma perfunctória, mostra-se interessante pois compatibiliza as críticas e observações da doutrina anteriormente apontados ao próprio discurso do Supremo Tribunal Federal.

Outro caso que se revela importante para a análise da questão é o julgamento da Arguição de Descumprimento de Preceito Fundamental n. 101.

A ADPF de relatoria da Min. Cármen Lúcia versa sobre pretensa violação de decisões judiciais em face do mandamento constitucional previsto no art. 225 da Constituição Federal, visando, em breve síntese, impedir a importação de pneus usados.

Sua análise revela-se importante ao presente trabalho pois se trata, em especial no cotejo dos votos dos Ministros Eros Grau, e da relatora, Ministra Cármen Lúcia, um debate sobre 
o ponto central de nossa discussão, os riscos sobre a utilização exacerbada de princípios e de conteúdos morais e valorativos no campo da fundamentação das decisões judiciais, mormente nos casos de grande relevo social frequentemente debatidos perante o Supremo Tribunal Federal.

A Arguição, cujo acórdão foi publicado no Diário da Justiça de 04 de junho de 2012, decidiu pela procedência da arguição, com a utilização da ponderação dos princípios constitucionais no sentido de que a importação de pneus usados viola os preceitos constitucionais de saúde e do meio ambiente ecologicamente equilibrado, arts. 170, inc. I e VI e seu parágrafo único, 196 e 225 da CF.

O voto do ministro Eros Grau, adota a mesma conclusão da ministra relatora no sentido de dar parcial procedência à arguição, contudo, sob fundamento diverso, e sobretudo naquilo que reside nossa especial atenção, com as críticas à utilização irrestrita de critérios de ponderação.

\begin{abstract}
Daí que os juízos de ponderação entre princípios de direito extirpam seu caráter de norma jurídica. Pretendo afirmar, com isto, que princípios de direito não podem, enquanto princípios, ser ponderados entre si. Apenas valores podem ser submetidos a essa operação. Dizendo-o de outro modo, a ponderação entre eles esteriliza o caráter jurídico-normativo que os definia como norma jurídica. Curiosamente, os princípios são normas, mas, quando em conflito uns com os outros, deixam de sê-lo, funcionando então como valores. A doutrina tropeça em si mesma ao admitir que os princípios, embora sejam normas jurídicas, não são normas jurídicas...

Juízes, especialmente os chamados juízes constitucionais, lançam mão intensamente da técnica da ponderação entre princípios quando diante do que a doutrina qualifica como conflito entre direitos fundamentais. Como contudo inexiste, no sistema jurídico, qualquer regra ou princípio a orientá-los a propósito de qual dos princípios, no conflito entre eles, deve ser privilegiado, essa técnica é praticada à margem do sistema, subjetivamente, de modo discricionário, perigosamente. A opção por um ou outro é determinada subjetivamente, a partir das pré-compreensões de cada juiz, no quadro de determinadas ideologias. Ou adotam conscientemente certa posição jurídicoteórica, ou atuam à mercê dos que detém o poder e do espírito do seu tempo, inconscientes dos efeitos de suas decisões, em uma espécie de "voo cego", na expressão de RÜTHERS. Em ambos os casos essas escolhas são perigosas. ${ }^{198}$
\end{abstract}

Ainda na trilha do voto do Ministro Eros Grau:

${ }^{198}$ BRASIL. Supremo Tribunal Federal. ADPF no 101, Plenário do Supremo Tribunal Federal. Voto do Ministro Eros Grau. Brasília, DF, 24 de junho de 2009. Disponível em: $<$ http://www.stf.jus.br/arquivo/cms/noticiaNoticiaStf/anexo/ADPF101ER.pdf>. Acesso em 23/11/2013. 
Pois é precisamente essa racionalidade que perece sempre que juízes operam a ponderação entre princípios. Daí a aguda observação de Habermas: enquanto uma corte constitucional adotar a teoria da ordem de valores e nela fundamentar sua práxis decisória, o perigo de juízos irracionais aumenta, porque os argumentos funcionalistas ganham prevalência sobre os normativos ${ }^{199}$.

A questão se resolveria segundo o voto do ministro Eros Grau sem a necessidade de utilização destes critérios, mas sim pela interpretação da Constituição e das normas aplicáveis.

Apenas para que se ilustre melhor a questão, ainda que sem a pretensão de uma análise exaustiva, a portaria n. 8/1991 do Departamento de Operações do Comércio Exterior DECEX, órgão veiculado ao Ministério do Desenvolvimento, Indústria e Comércio Exterior, em seu art. 27, impediria a importação de bens de consumo usados.

Haveria ainda fundamento no disposto na resolução n. 23/1996 do Conselho Nacional do Meio Ambiente - CONAMA, a qual expressamente veda em seu art. 4. a importação de pneumáticos usados, bem como vedações no disposto nas resoluções 258/1999 e 301/2002, também do CONAMA.

Os diplomas se coadunam ainda com a Convenção de Basiléia sobre o Controle de Movimentos Transfronteiriços de Resíduos Perigosos e seu Depósito, promulgada pelo governo nacional por meio do Decreto 875 de 1993.

A fundamentação do voto do Ministro Eros Grau toca na questão, e corrobora os questionamentos já delineados.

A leitura da decisão permite observar que a utilização da ponderação entre princípios era argumento que poderia, segundo entendimento do ministro, ser evitado.

Das cento e quarenta páginas que compõem o voto da Ministra Cármen Lúcia, grande parte dos argumentos baseia-se em critérios de ponderação entre princípios ou remissões a argumentos que transbordam o discurso jurídico, quando em verdade, a questão poderia ter se resolvido na legislação aplicável ao caso e sua compatibilidade com o bloco de

199 Idem, ibidem. 
constitucionalidade, questão que a relatora enfrenta a partir da página cento e vinte e três de seu voto.

As críticas apontadas pelo ministro e professor Eros Grau, como a de Habermas e a de Carl Schmitt, encontrada em seu texto A Tirania dos Valores, reproduzida no corpo do acórdão do ministro, trazem o alerta sobre os riscos da utilização indistinta de critérios de sopesamento, da eleição de valores casuísticos nas fundamentações das decisões proferidas pelo Supremo Tribunal Federal.

Ainda que não adentremos a análise exaustiva do julgamento, a tônica do debate, mormente no do voto do ministro Eros Grau representa de forma interessante o debate doutrinário trazido no desenvolvimento do presente capítulo, com os riscos que uma excessiva moralização do Direito e o uso dos chamados princípios e seu sopesamento podem trazer. 


\title{
5. A PROBLEMÁticA ENTRE ATIVISMO JUDICIAL E DEMOCRACIA
}

As críticas apontadas nos dois capítulos anteriores nos inserem na problemática entre o ativismo judicial e a democracia.

Ainda que de forma breve, faz-se necessário trazer alguns conceitos de democracia, termo que comporta diversos significados e gradações, mas que cremos poder resumir-se em uma ideia central.

Segundo a abordagem de Robert Dahl, o conceito de democracia comporta uma variedade de definições, mas que pode ser identificado segundo cinco critérios, sendo eles, a participação efetiva, na qual "todos os membros devem ter oportunidades iguais e efetivas para fazer os outros membros conhecerem suas opiniões sobre qual deveria ser esta política"; a igualdade de voto, pela qual "todos os membros devem ter oportunidade iguais e efetivas de voto e todos os votos devem ser contados como iguais"; o entendimento esclarecido, critério segundo o qual "dentro de limites razoáveis de tempo, cada membro deve ter oportunidades iguais e efetivas de aprender sobre as políticas importantes e suas prováveis consequências"; o controle do programa de planejamento, em que "os membros devem ter a oportunidade exclusiva para decidir como e, se preferirem, quais as questões que devem ser colocadas no planejamento"; inclusão de adultos, pelo qual "todos ou, de qualquer maneira a maioria dos adultos residentes permanentes, deveriam ter o pleno direito dos cidadãos implícito no primeiro de nossos critérios"200.

Manoel Gonçalves Ferreira Filho traz alguns princípios da democracia contemporânea, sob o ângulo jurídico, que nos ajudam a construir um núcleo de postulados sobre o atual conceito de democracia:

\begin{abstract}
A democracia contemporânea, do ângulo jurídico, pode ser resumida nalguns princípios. Ou seja: 1) ela tem o povo como fonte de todo poder - princípio da soberania popular; 2) todavia, o povo não exerce o poder, mas o faz por meio de representantes - princípio representativo - embora excepcionalmente o exerça; 3)tal poder é, ademais, limitado por freios e contrapesos e, sobretudo, pelo reconhecimento de direitos fundamentais em favor dos seres humanos princípio da limitação do poder ${ }^{201}$.
\end{abstract}

${ }^{200}$ DAHL, Robert A. Sobre a democracia. Beatriz Sidou (Trad.). Brasília: Editora Universidade de Brasília, 2009. p. 50.

${ }^{201}$ FERREIRA FILHO, Manoel Gonçalves. Princípios Fundamentais do Direito Constitucional. 2. ed. São Paulo: Saraiva, 2010.p. 51. 
Os conceitos acima trazidos, com a autoridade dos importantes autores citados, nos permitem a análise sobre a tensão entre estes dois polos, o ativismo judicial, mormente dentro das feições até aqui traçadas, e a democracia.

Para que a discussão não incida em reducionismos ${ }^{202}$ ou mesmo em uma perspectiva maniqueísta sobre o assunto, parece-nos necessário, para além da crítica a esta imersão do Supremo Tribunal Federal em um ativismo judicial, tomado sob o ponto de vista adotado nos parágrafos anteriores, trazer possíveis pontos de equilíbrio nesta nova característica da atuação do Poder Judiciário.

Isto porque, ainda que entendêssemos como procedentes as contumazes críticas à moralização do Direito, à assunção de uma jurisprudência de valores no âmbito de nossa Corte Constitucional, ao quadro montado pela conjugação do avanço de nosso sistema de controle de constitucionalidade e à abertura semântica do texto constitucional, com o consequente alargamento dos parâmetros de aferição de nosso bloco de constitucionalidade, podemos estar diante de um cenário cujos influxos na história apenas o confirmarão como uma realidade inexorável, razão pela qual, faz-se necessária uma reflexão sobre possíveis formas de contenção de exageros voluntaristas, na busca de um reequilíbrio com postulados básicos de um regime democrático.

Primeiramente, passamos a apontar as críticas sobre os influxos deste ativismo judicial com relação aos postulados democráticos, relembrando alguns pontos já trazidos em capítulos anteriores, sob o aspecto de um possível esvaziamento da própria democracia, para então trazermos alguns apontamentos sobre possíveis pontos de equilíbrio da questão.

\footnotetext{
${ }^{202}$ A observação de Daniel Sarmento parece incidir como reforço na necessidade de uma crítica com os olhos voltados à crítica necessária ao quadro vivenciado na atualidade, porém, de forma a construir dentro desta realidade uma possível melhoria do sistema. "A hermenêutica constitucional não deve ser construída a partir de idealizações contrafáticas dos intérpretes, sejam elas o "juiz Hércules" de Dworkin, o legislador que encarna a vontade geral do povo, ou até mesmo o dirigente de agência reguladora completamente técnico, apolítico e independente. No debate jurídico brasileiro, é preciso superar a cegueira diante das capacidades institucionais reais dos agentes que interpretam e aplicam as normas, para construir teorias mais realistas, que possam produzir, na prática, resultados que otimizem os valores constitucionais". (SARMENTO, Daniel. Interpretação Constitucional, Pré-compreensão e Capacidades Institucionais do Intérprete. In BINENBOJM, Gustavo (coord); SOUZA NETO, Cláudio Pereira de; SARMENTO, Daniel. Vinte Anos da Constituição Federal de 1988. Rio de Janeiro: Lumen Juris, 2009. p. 321).
} 
Pode-se verificar um paradoxo no enfretamento da questão. Após décadas de regime marcado pela excepcionalidade, pela ausência de participação democrática, a Carta de 1988 alberga uma série de conquistas dos mais diversos setores sociais.

Preencheu-se seu conteúdo com uma vasta cartilha de Direitos, os quais incorporaram conteúdo moral amplo e de forte viés axiológico, típico das sociedades pluralistas, para então, após aproximadamente duas décadas de sua vigência, estas questões nascidas de um clamor social tornarem-se de certa forma distantes do âmbito da deliberação popular, entendido seu exercício primordialmente por meio da participação no processo político, tendo seu alcance e significado discutidos por meio de processos judiciais, sobretudo, no âmbito de um modelo de controle de constitucionalidade preponderantemente abstrato e concentrado, ainda que em certo ponto aberto à participação por meio de instrumentos como o amicus curiae e a realização de audiências públicas e pelo alargamento do rol de legitimados ativos.

Corroborando o exposto, cabe a transcrição da observação feita por Jorge Octávio Lavocat Galvão:

Relativamente ao Brasil, no começo de sua experiência democrática, uma Corte Constitucional com amplos poderes fazia-se necessária para fortalecer o compromisso com os direitos fundamentais e aniquilar os espectros da ditadura. Vinte anos depois, entretanto, a população depara-se com a possibilidade de ter restringida sua participação na tomada de decisões político-sociais ${ }^{203}$.

É neste possível afastamento da população em relação à participação no processo de tomada destas decisões, de desenvolvimento e adensamento de nossa Constituição, que se encontra o principal ponto de tensão entre o ativismo judicial e a democracia.

Partindo da análise de Jorge Octávio Lavocat Galvão, pode-se observar a tensão entre a atividade judicial tal como delineada nos capítulos anteriores e a democracia, quando as Cortes Constitucionais assumem a tarefa de interpretação e propriamente da construção do significado, do adensamento, dos postulados de conteúdo aberto, nos quais repousam as questões fundamentais da sociedade:

\footnotetext{
${ }^{203}$ GALVÃO, Jorge Octávio Lavocat. Concentração de Poder da Jurisdição Constitucional: Uma análise crítica de seus pressupostos filosóficos. In: ALMEIDA, Fernando Dias Menezes de; AMARAL JÚNIOR, José Levi Mello do; LEAL, Roger Stiefelmann; HORBACH, Carlos Bastide (Coord.). Direito Constitucional, Estado de Direito e Democracia: Homenagem ao Prof. Manoel Gonçalves Ferreira Filho. São Paulo: Quartier Latin, 2011. p. 391.
} 


\begin{abstract}
Os juízes discordam sobre interpretação judicial na mesma proporção em que as pessoas comuns discordam sobre a moralidade coletiva. Os termos vagos em que as Cartas Constitucionais não fornecem nenhuma resposta para os casos constitucionais difíceis, como aborto, eutanásia, pesquisa com células-tronco e ações afirmativas. A única certeza é que a população vai ser diretamente afetada por alguma concepção particular de direito acolhida pela maioria dos membros da Suprema Corte. Nessas questões de moralidade política, não há nenhuma garantia que o ponto de vista adotado pelos juízes seja superior ao dos outros membros da sociedade ${ }^{204}$.
\end{abstract}

De acordo com as críticas já expostas no capítulo intitulado "O Poder Judiciário como intérprete de valores e conteúdos morais da sociedade", nota-se que o exercício de atividade judicial sobre os chamados casos difíceis, ou desacordos morais razoáveis, utilizando terminologia de Jeremy Waldron, propiciado sobretudo pela natureza de nosso próprio texto constitucional e pela configuração de nossos sistema de controle de constitucionalidade, desloca a construção do adensamento destes conceitos abertos, o próprio processo de maturação de questões fundamentais a toda a sociedade ao âmbito restrito, se comparado à amplitude e alcance do sufrágio, do processo judicial.

A agenda do Supremo Tribunal Federal e de diversas Cortes Constitucionais ao redor do mundo tem mostrado que as grandes questões que afetam diretamente toda a pluralidade dos atores sociais têm sido decididas fora do debate político democrático travado nos parlamentos, sem a participação efetiva destes mesmos atores, para adentrar os gabinetes e plenários dos Tribunais, como o novo foro de discussão e construção destes novos temas.

A preocupação central aqui exposta não reside simplesmente na possibilidade de discussão destas grandes questões pelo Poder Judiciário, pois se estas compõem o conteúdo da Constituição invariavelmente serão objeto de sua análise, mas sim da linha tênue hoje existente na aferição da constitucionalidade destas questões quando o parâmetro de aferição mostra-se extremamente fluído, dificultando precisar se o Poder Judiciário exerce sua função nos limites essenciais a ele confiados ou se em verdade transborda o núcleo essencial de sua função, colocando-se como legislador ou poder constituinte concorrente.

\footnotetext{
${ }^{204}$ GALVÃO, Jorge Octavio Lavocat. Concentração de Poder da Jurisdição Constitucional: Uma análise crítica de seus pressupostos filosóficos. In: ALMEIDA, Fernando Dias Menezes de; AMARAL JÚNIOR, José Levi Mello do; LEAL, Roger Stiefelmann; HORBACH, Carlos Bastide (coord.). Direito Constitucional, Estado de Direito e Democracia: Homenagem ao Prof. Manoel Gonçalves Ferreira Filho. São Paulo: Quartier Latin, 2011. p. 382-3.
} 
Parece-nos correto observar que dentro de um quadro em que se conclama uma constitucionalização ampla de todo o sistema jurídico, e, estes parâmetros constitucionais mostram-se de extrema imprecisão semântica, com largas margens interpretativas, há uma depreciação do valor das próprias normas inferiores à Constituição, fruto de um processo legislativo cuja tônica é, ou ao menos deveria ser, correspondente ao resultado do processo deliberativo democrático.

Sob o aspecto da participação popular, núcleo do postulado democrático, ainda que casos como o julgamento da ADI 3.510 tenham se mostrado exemplares do ponto de vista de uma maior abertura para a participação da sociedade no processo de formação da decisão final, certamente não se está diante de um locus deliberativo amplo, como seria em sua forma ideal uma casa legislativa, pelo menos na ótica da amplitude da participação popular.

Neste ponto fazemos a ressalva ao pensamento de Conrado Hübner Mendes. Se do ponto de vista da amplitude da participação haveria uma diferença quantitativa entre o processo legislativo e o processo judicial, no que concerne à qualidade deste processo deliberativo, devemos registrar aqui seu argumento, no sentido de que nas Cortes haveria um grau máximo de racionalidade, cujo processo de decisão é fruto do exercício da argumentação, "o ponto institucional mais próximo da "situação ideal de discurso", um padrão regulativo que concebe um ambiente em que todos os participantes da deliberação tenham igual oportunidade de falar e não sofram constrangimentos de nenhum tipo. ${ }^{205,}$

Assim, segundo se nota da observação colacionada, a Corte se mostraria privilegiada na discussão destas questões ${ }^{206}$.

\footnotetext{
${ }^{205}$ MENDES, Conrado Hübner. Desempenho deliberativo de cortes constitucionais e o STF. In: BARBIERI, Catarina Helena Cortada; MACEDO JÚNIOR, Ronaldo Porto (Org.). Direito e interpretação: racionalidades e instituições. São Paulo: Saraiva, 2011. p. 346.

${ }^{206}$ Vale trazer o argumento de Oscar Vilhena Vieira, o qual trilha o mesmo raciocínio de Conrado Hübner Mendes. Vejamos: "O ponto crucial de controle desta atividade argumentativo-decisória é a obrigação do magistrado fundamentar e justificar as razões que levaram a uma determinada decisão É este imperativo, inexistente na esfera do legislativo, que faz o procedimento argumentativo-decisório, levado a cabo pelo judiciário, um instrumento mais propício para se decidir questões de princípios, uma vez que "os motivos bem redigidos deve fazer-nos conhecer com fidelidade todas as operações da mente que conduziram o juiz ao dispositivo adotado por ele." (VIEIRA, Oscar Vilhena. A moralidade da Constituição e os Limites da Empreitada Interpretativa, ou entre Beethoven e Bernstein. In: SILVA, Virgilio Afonso da (org). Interpretação Constitucional. São Paulo: Malheiros Editores, 2007. p. 252)
} 
Mesmo se tomássemos como premissa válida a assertiva do parágrafo anterior, nos parece que ainda que exista um maior grau de racionalidade argumentativa, uma maior carga dialética, sob o ponto de vista da participação esta se mostra restrita se comparada com ao alcance quantitativo, atingido no processo político democrático.

A observação de Daniel Sarmento corrobora o exposto, e com as críticas já apontadas anteriormente, ao questionar a legitimidade de uma sociedade cuja base é a democracia, "amputar a liberdade de conformação do legislador em nome da irradiação de normas constitucionais, sobretudo diante da constatação que o grande "agente" desta irradiação é o juiz, que não é eleito e não responde politicamente perante o povo"207.

No cotejo entre este ambiente de hiper moralização do Direito e do consequente ativismo realizado pelas Cortes superiores, Daniel Sarmento aponta os caracteres deletérios deste fenômeno, dentre eles uma violação ao núcleo essencial da democracia.

\begin{abstract}
Esta prática é profundamente danosa a valores extremamente caros ao Estado Democrático de Direito Ela é prejudicial à democracia, porque permite que juízes não eleitos imponham as suas preferências e valores aos jurisdicionados, muitas vezes passando por cima de deliberações do legislador. Ela compromete a separação de poderes, porque dilui a fronteira entre as funções judiciais e legislativas. E ela atenta contra a segurança-jurídica, porque torna o Direito muito menos previsível, fazendo-o dependente das idiossincrasias do juiz de plantão, e prejudicando com isso a capacidade do cidadão de planejar a própria vida com antecedência, de acordo com o conhecimento prévio do ordenamento jurídico. Ela substitui, em suma, o governo da lei pelo governo dos juízes ${ }^{208}$.
\end{abstract}

Ainda nesta linha argumentativa, a crítica de Humberto Ávila toca de forma central e sintetiza aquilo que nos parece o principal ponto desta problemática:

O paradigma da ponderação, tal qual aqui analisado, aniquila com as regras e com o exercício regular do princípio democrático por meio da função legislativa. A Constituição Brasileira de 1988, além de estabelecer que nada poderá ser exigido senão em virtude de lei e de prever que todo poder emana do povo, que o exercerá por meio de representantes eleitos ou diretamente, reserva ao Poder Legislativo, inúmeras vezes em numerosas matérias, a competência para regular, por lei, determinado âmbito normativo. Ao se admitir o uso dos princípios constitucionais, mesmo naquelas situações em que as regras legais são compatíveis com a Constituição e o emprego dos princípios ultrapasssa a interpretação teleológica pelo abandono da hipótese legal, está-se, ao mesmo

${ }^{207}$ SARMENTO, Daniel. Ubiquidade constitucional: os dois lados da moeda. In: SARMENTO, Daniel. Livres e iguais: estudos de direito constitucional. Rio de Janeiro: Lumen Juris, 2006. p. 191.

${ }^{208}$ Idem, ibidem. p. 179. 
tempo, consentindo com a desvalorização da função legislativa e, por decorrência, com a depreciação do papel democrático do Poder Legislativo ${ }^{209}$.

A análise de Humberto Ávila, assim como as críticas de outros autores citados, tomando por exemplo Jürgen Habermas, trabalham com a hipótese do exercício do paradigma da ponderação, técnica utilizada em larga escala no cotejo destas normas de conteúdo amplo e vago presentes na Constituição.

A crítica se amolda mesmo às situações em que não se esteja tratando especificamente de ponderação de princípios, mas também de quaisquer outras formas de manejo destas questões, quando o alto grau de indeterminação que subjaz aos parâmetros presentes na Constituição acaba por mover a atividade judicial para o terreno de opções mais afetas à discricionariedade e ao campo das escolhas políticas do que ao campo de uma atividade de controle e de aferição de constitucionalidade centradas em contornos normativos claros.

Se a função judicial não se mostra como a mais democrática, se seu núcleo essencial se afasta propositalmente desta característica para justamente controlar a aplicação do próprio Direito, ao avocar a autoridade sobre a tradução destes conceitos abertos, cuja carga valorativa e moral tem inundado o espaço de fundamentação destas decisões judiciais, o ativismo judicial tende a deslocar para o campo do processo judicial a atividade típica que se desenvolve em um processo político democrático.

Novamente pedimos vênia para a transcrição do pensamento de Humberto Ávila:

\begin{abstract}
O Poder Judiciário não deve assumir, em qualquer matéria e em qualquer intensidade, a prevalência na determinação da solução entre conflitos morais porque, num Estado de Direito, vigente numa sociedade complexa e plural, deve haver regras gerais destinadas a estabilizar conflitos morais e reduzir a incerteza e a arbitrariedade decorrente de sua inexistência ou desconsideração, cabendo à sua edição ao Poder Legislativo e a sua aplicação, ao Judiciário ${ }^{210}$.
\end{abstract}

Tomado o núcleo essencial da Democracia como exposto nos primeiros parágrafos deste capítulo, parece claro que uma atuação do Poder Judiciário afeta, ou altera substancialmente a lógica de um processo democrático quando esta função do poder passa

${ }^{209}$ ÁVILA, Humberto. "Neoconstitucionalismo": entre "Ciência do Direito" e o "Direito da Ciência". In: BINENBOJM, Gustavo; NETO, Cláudio Pereira de Souza; SARMENTO, Daniel (Coord.). Vinte Anos da Constituição Federal de 1988. Rio de Janeiro: Lumen Juris, 2009. p. 193.

${ }^{210}$ Idem, ibidem. p. 200. 
a navegar por campos cujas balizas ultrapassam os limites do ordenamento e do decidido por meio do processo legislativo, substituindo as próprias escolhas tomadas de forma democrática, ou ainda, avançando em relação a escolhas e adensamento de temas que, mais cedo ou mais tarde, seriam objeto de discussão na sociedade.

$\mathrm{Na}$ ótica apontada por Elival da Silva Ramos e explorada nos capítulos anteriores, a atuação do Poder Judiciário sob os auspícios de uma jurisprudência de valores ou mesmo sob a influência de um moralismo jurídico, que tem influenciado as decisões de nossa Corte Suprema, deteriora os postulados da separação de poderes e do Estado Democrático de Direito, e por consequência, da própria democracia.

O professor de Direito Constitucional da Faculdade de Direito do Largo de São Francisco aponta a necessidade da manutenção de balizas normativas à interpretação judicial, sob pena de violação dos postulados básicos do Estado de Direito, dentre eles a própria democracia.

Segundo Elival da Silva Ramos, "embora seja evidente a enorme penetração do moralismo jurídico na Dogmática constitucional, entendo mais compatível com os ideais democráticos a linha de um positivismo renovado" 211 .

É dentro deste positivismo renovado que Elival da Silva Ramos procura encontrar formas de contenção ao ativismo judicial, buscando compatibilizar os avanços da hermenêutica, como a teoria estruturante do Direito de Friedrich Müller, com os postulados básicos, porém renovados do positivismo jurídico.

Segundo o autor:

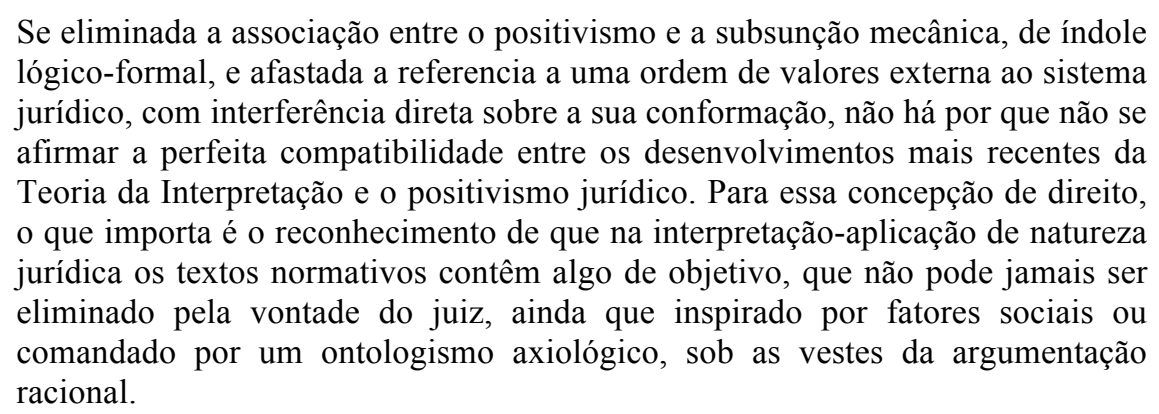

${ }^{211}$ RAMOS, Elival da Silva. Ativismo Judicial: parâmetros dogmáticos. São Paulo: Saraiva, 2010. p. 103. 
Esta opção busca justamente afastar o choque entre a atividade judicial, quando praticada por terrenos movediços de uma filosofia moral ou valorativa sem parâmetros claros, e os postulados da democracia, dentre outros citados pelo autor.

Na visão encampada em sua obra Ativismo Judicial: parâmetros dogmáticos, esta nova atuação do poder judiciário ao se afastar de critérios hermenêuticos claros, lastreados em um núcleo essencial de normatividade, avança para campos que desbordam de sua função essencial, e assim violam o postulado democrático.

Ao lado destas visões, cujas conclusões apontam para um choque entre o postulado democrático e a atuação das Cortes Constitucionais, vista sob o enfoque até aqui tratado, necessário trazermos a abordagem que coloca a jurisdição constitucional não em rota de colisão com a democracia, mas em posição de complementaridade, de participação dentro deste processo.

Esta constatação pode ser encontrada na obra de Conrado Hübner Mendes, "Direitos fundamentais, separação de poderes e deliberação."

Partindo da ótica de uma teoria da separação de poderes dinâmica, em que há alternância na legitimidade entre os diversos poderes no campo da deliberação sobre estas questões fundamentais, justificar-se-ia a assunção do Poder Judiciário a este espaço outrora pertencente ao processo político democrático exercido no âmbito do Poder Legislativo.

Segundo o pensamento exposto, “a opinião pública interage e é responsável por flutuações de legitimidade" ${ }^{, 212}$. Ainda citando o autor "Instituições constroem capital político difuso e passam a gerenciá-lo em decisões mais ou menos populares",213.

Haveria assim uma alternância de legitimidade das Instituições para além de um ideal procedimentalista da democracia.

${ }^{212}$ MENDES, Conrado Hübner. Direitos fundamentais, separação de poderes e deliberação. São Paulo: Saraiva, 2011. p. 186.

${ }^{213}$ Idem, ibidem. p. 186. 
Se concordarmos que as variáveis de legitimidade da democracia não se esgotam no procedimento, mas abrangem também os resultados, passa a ser aceitável que a substância subordine, em algumas circunstâncias, o procedimento, ou seja, que a instituição que tenha alcançado a resposta mais compatível com um critério substantivo de legitimidade tenha boas razões para prevalecer independentemente de seu pedigree (subvertendo a estrutura formal) ${ }^{214}$.

Ao observarmos o debate político nacional dos últimos anos, nos parece que esta constatação pode ser feita.

Como já mencionado, o Supremo Tribunal Federal absorveu uma extensa pauta de grandes questões políticas da nação, as quais, de acordo com a visão posta nos parágrafos acima, deveria ser fruto de um debate democrático em sua acepção que ordena a ampla participação popular.

Observa-se, porém, que a opinião pública tem de certa forma legitimado estas decisões e o papel assumido por nossa Corte Suprema.

O papel assumido pelo Supremo Tribunal Federal no ideário popular não parece colocá-lo "na berlinda", parece sim haver uma aceitação da população sobre este novo papel de nossa Corte, por maior que seja o distanciamento entre o debate travado nesta Corte e a efetiva participação da população.

O conceito utilizado pelo autor assemelha-se à visão de John Rawls sobre a difusão de legitimidade entre as três funções essenciais, Executiva, Legislativa e Judiciária, com destaque inclusive para a jurisdição constitucional, para o exercício da chamada razão pública $^{215}$.

${ }^{214}$ MENDES, Conrado Hubner. Direitos fundamentais, separação de poderes e deliberação. São Paulo: Saraiva, 2011. p.194.

${ }^{215}$ De acordo com a concepção de Rawls: "A razão pública é a característica de um povo democrático: é a razão de seus cidadãos, daqueles que compartilham do status da cidadania igual. O objeto da razão dos cidadãos é o bem do público, aquilo que a concepção política de justiça requer da estrutura básica institucional da sociedade e os propósitos e fins a serviço dos quais tal estrutura deve se colocar." (RAWLS, John. O liberalismo político. ed. ampl. Álvaro de Vita (Trad.). São Paulo: WMF Martins Fontes, 2011. p. 250-1). A Corte Constitucional, da mesma forma do que ocorre aos demais poderes, seria espaço de exercício desta razão pública, dentro de uma concepção de democracia e de separação de poderes cuja legitimidade mostra-se atrelada sobretudo à fórmula da razão pública, não se esgotando no procedimento democrático, mas sim legitimando-se também por razões substantivas. 
As Cortes Constitucionais ao articularem esta razão pública, subjacente ao texto constitucional e nele consagrada, trazem o equilíbrio dentro de uma democracia constitucional, de caráter dualista segundo Rawls, a qual "distingue o poder constituinte do poder ordinário, bem como a lei mais alta do povo da lei ordinária aprovada por instituições legislativas. A supremacia parlamentar é rejeitada ${ }^{216 "}$.

Ainda prosseguindo na visão de John Rawls, "ao aplicar a razão pública, o tribunal age para evitar que a lei seja erodida pela legislação de maiorias transitórias ${ }^{217}$,"

A teoria apresentada por Conrado Hübner Mendes trabalha um meio termo entre o procedimento e a substância das decisões, por meio de um diálogo entre os poderes, um processo dinâmico em que há alternância entre Judiciário, Legislativo e Executivo, pelo qual "é desejável que poderes desafiem uns aos outros (...) desde que articulem razões de melhor qualidade" 218 .

Segundo o autor, uma teoria em que haja supremacia absoluta do parlamento "dificulta que críticas substantivas às decisões legislativas tenham expressão institucional, exceto na própria via parlamentar" ${ }^{219}$. Em uma teoria da separação de poderes de legitimidade flutuante, o controle de constitucionalidade "opera um contrapeso inserido no próprio coração do arranjo de forças" 220 .

A teoria do diálogo "ao relativizar a última palavra, mostra que a alternativa à supremacia do parlamento não é necessariamente soberania, pura e simples, da corte, mas um jogo interativo rico e complexo" 221 .

Esta concepção de diálogo busca afastar aquilo que o autor chama de cultura do guardião, pela qual a Corte Constitucional coloca-se em posição de detentor da última palavra sobre os direitos fundamentais e sobre as questões afetas ao controle de constitucionalidade, o que dentro do quadro desenhado ao longo deste trabalho, o colocaria em uma posição de

${ }^{216}$ RAWLS, John. O liberalismo político. ed. ampl. Álvaro de Vita (Trad.). São Paulo: WMF Martins Fontes, 2011. p. 275.

${ }^{217}$ Idem, ibidem. p. 276.

${ }^{218}$ MENDES, 2011, op. cit., p. 195. MENDES, Conrado Hubner. Direitos fundamentais, separação de poderes e deliberação. São Paulo: Saraiva, 2011.

${ }^{219}$ Idem, ibidem. p. 201.

${ }^{220}$ Idem, ibidem. p. 201.

${ }^{221}$ Idem, ibidem. p. 202. 
clara proeminência sobre os demais poderes, correndo o risco de subverter inclusive o ideal democrático.

Segundo Conrado Hübner Mendes:

\begin{abstract}
A cultura do guardião não é prejudicial apenas porque rejeita a participação genuína do legislador na formulação do significado constitucional, mas também porque the confere uma isenção de responsabilidade. Numa posição cômoda, não precisa preocupar-se com a constitucionalidade de seus próprios atos. Não se lhe demanda uma prestação de contas argumentativa. Há muitas evidências de tal cultura. Com muita frequência, especialmente no voto de alguns ministros do STF, anuncia-se espalhafatosamente a supremacia do $\operatorname{STF}^{222}$.
\end{abstract}

Faz-se ainda uma crítica, que parte da constatação de nosso modelo institucional pela qual "a cultura constitucional brasileira, razoavelmente majoritária, vê no STF a autoridade última e monopolística para revelar o significado da constituição" ${ }^{, 22}$. De acordo com este ideário, haveria um desestímulo a que o legislador dialogasse com o Judiciário, desafiasse suas decisões, o processo que deveria ser flutuante e dinâmico encerraria seu circuito com a decisão final e suprema da Corte Constitucional.

A cultura constitucional tem se postado de forma adversarial, e não interativa como sugere e constata o autor, são citados alguns exemplos do diálogo proposto pelo autor entre os poderes, como no caso das ADI n. 1.351 e 1.354, no qual houve movimentação do parlamento para a edição da PEC 02/2007, criando uma nova espécie de cláusula de barreira, em resposta à decisão do Supremo Tribunal Federal que declarou a inconstitucionalidade da chamada cláusula de barreira, e, o julgamento do RE 197.208/RS que negou a extensão da licença-maternidade às mães adotivas, o que gerou uma série de projetos parlamentares visando contemplar estes direitos restringidos segundo a interpretação dada pelo $\mathrm{STF}^{224}$.

A visão adotada por Conrado Hübner Mendes propõe um modelo, ainda que esteja distante da prática diária de nossas Instituições, em que se busca um novo conceito de separação de poderes, havendo legitimidade para as Cortes Constitucionais na discussão das grandes pautas, ainda que demandem o ingresso em terrenos morais e valorativos, desde que haja

${ }^{222}$ MENDES, 2011, op. cit., p. 218. MENDES, Conrado Hubner. Direitos fundamentais, separação de poderes e deliberação. São Paulo: Saraiva, 2011.

${ }^{223}$ Idem, ibidem. p. 219.

${ }^{224}$ Idem, ibidem. p.224-5. 
um diálogo interinstitucional, cuja legitimidade das decisões é posta à prova não por um viés procedimental ou pautado em desenhos institucionais a priori para a definição de seus caráter democrático, mas sim pela qualidade da substância, do resultado do processo, por meio da aceitabilidade das decisões pela opinião pública e pelo controle e respostas dadas pelos demais poderes.

Mesmo que esta fosse uma proposta válida para o enfrentamento da questão, e ao menos em teoria se mostra razoável e factível, deve-se buscar um ponto de equilíbrio ou formas de correção aos desvios apontados por esta atuação ativista dos Tribunais, observada pelas procedentes críticas expostas no início deste capítulo e nos dois que o antecedem.

Feitas estas considerações, passamos a expor como proposto no início desta explanação, para além da crítica, pontos de equilíbrio na tensão proposta.

Consoante aponta Luiz Roberto Barroso, há necessidade de encontro de um "ponto de equilíbrio entre supremacia da Constituição, interpretação constitucional pelo Judiciário e processo político majoritário" ${ }^{\text {225. }}$.

Este ponto de equilíbrio tem se mostrado como uma difícil tarefa na práxis de nossos Tribunais, sobretudo em nossas Cortes Superiores, cujo maior representante é o Supremo Tribunal Federal, talvez pela banalização dos critérios hermenêuticos necessários, ou como apontado por Carlos Ari Sundfeld, por um ambiente de preguiça, como denota o título de seu artigo anteriormente citado, na utilização e no manejo deste bloco de constitucionalidade tão difuso, cujo conteúdo parece, com o perdão da metáfora, soar como o canto das sereias à Ulisses aos ouvidos de parte de seus intérpretes e aplicadores.

A tarefa de interpretação constitucional por parte do Poder Judiciário deve encontrar este equilíbrio, de modo a evitar um retrocesso, ou mesmo uma negativa a uma realidade subjacente aos textos constitucionais atuais, sem contudo trazer à ruina princípios organizacionais básicos e essenciais ao equilíbrio institucional entre os Poderes e a preservação de um, ainda que desacreditado, princípio democrático.

\footnotetext{
${ }^{225}$ BARROSO, Luís Roberto. Neoconstitucionalismo e constitucionalização do direito (O triunfo tardio do direito constitucional no Brasil). In: Revista de Direito Constitucional e Internacional: Caderno de Direito Constitucional e Ciência Política, ano 15, n. 58, p. 173, janeiro-março/2007.
} 
A respeito do tema, afirma Jorge Miranda:

\begin{abstract}
A interpretação constitucional tem de ter em conta condicionalismos e fins políticos inelutáveis e irredutíveis, mas não pode visar outra coisa que não sejam os preceitos e princípios jurídicos que lhes correspondem. Tem de olhar para a realidade constitucional, mas tem de a saber como sujeita ao influxo da normas e não como mera realidade de facto. Tem de racionalizar sem formalizar. Tem de estar atenta aos valores sem dissolver a lei constitucional no subjectivismo ou na emoção política. Tem se de fazer mediante a circulação da norma - realidade constitucional $^{226}$.
\end{abstract}

Se a natureza de nossa Constituição e de nosso sistema de controle de constitucionalidade possibilita esta atuação ativista do Poder Judiciário, nos parece que a moderação no exercício da função judicial, sobretudo em sede de controle de constitucionalidade passa fundamentalmente pelo desenvolvimento de uma mentalidade de autocontenção no interior de nossos Tribunais, sobretudo no Supremo Tribunal Federal.

Nas palavras de Dimitri Dimoulis, "A doutrina da autocontenção convida os julgadores a abster-se de um juízo de inconstitucionalidade que não possui plena justificativa e compromete o equilíbrio entre os poderes estatais",227.

A tese da autocontenção busca estabelecer uma moderação entre o intervencionismo judicial exacerbado, sobretudo em questões controvertidas, como as que tem sido pauta constante de nosso Supremo Tribunal Federal, e o passivismo judicial indesejado.

Esta autolimitação passa sobretudo pelo desenvolvimento de uma cultura minimalista no interior dos próprios Tribunais, da conscientização de que não haveria uma espécie de necessidade de pronunciamento final da Corte sobre toda e qualquer matéria política relevante a ele submetidas, mas sim ao reconhecimento de que os juízos de inconstitucionalidade somente devem ser procedidos diante de clara violações à Constituição, sem que se avance ao campo do protagonismo judicial sobre estas questões, respeitando os espaços de conformação legislativa e democráticas destas questões.

\footnotetext{
${ }^{226}$ MIRANDA, Jorge. Manual de Direito Constitucional. Tomo II. Constituição. 5a. ed. Coimbra: Coimbra Editora, 2004. p. 288.

227 DIMOULIS, Dimitri; LUNARDI, Sara. Ativismo e autocontenção judicial no controle de constitucionalidade. In FELLET, André Luiz Fernandes; NOVELINO, Marcelo; PAULA, Daniel Giotti de. As nova faces do ativismo judicial.Bahia: Jus Podivm, 2013. p. 471.
} 
O desenvolvimento de uma cultura de autocontenção ocorrerá com o próprio amadurecimento de nossas Cortes Superiores, tendo em vista que esta tese, segundo Dimitri Dimoulis, “carece de embasamento jurídico, pois não há dispositivo que impõe aos tribunais declarar a inconstitucionalidade só em casos excepcionais ou manifestos. $" 228$

Não se advoga aqui por um self restraint rigoroso, que tenda a aleijar a atuação do Supremo Tribunal Federal ou negar o conteúdo substancial de nossa Constituição, mas sim uma autocontenção que, no que diz respeito ao manejo destas cláusulas abertas, passe pela melhoria da qualidade da argumentação e da fundamentação das decisões.

Esta busca por um equilíbrio passa pela autocontenção a ser realizada pelos próprios Tribunais, por um processo de conscientização e de resgate, e fala-se aqui em resgate, uma vez que teorias do protagonismo judiciário parecem pugnar por rompimento com os mesmos, a alguns postulados básicos da Teoria do Direito e do Constitucionalismo, como a manutenção de um núcleo essencial da teoria da separação de poderes, a uma dogmática jurídica, ainda que modificada, atrelada a mínimos essenciais do positivismo jurídico, previsibilidade e critérios de operacionabilidade que mantenham a coerência do sistema normativo.

Deste contexto são de grande valia as contribuições de Elival da Silva Ramos, a utilização do que o autor chama de um positivismo renovado como forma de contenção à atividade judicial, sobretudo em campos nos quais as normas têm se mostrado de conteúdo semântico fluído, como ocorre no manejo da Constituição em sede dos processos de controle de constitucionalidade.

Deve haver uma valorização deste positivismo renovado, já mencionado em parágrafos anteriores, o qual vai além da subsunção mecânica da norma para a incorporação da nova realidade hermenêutica, sem que se despreze o núcleo essencial das balizas do texto normativo.

228 DIMOULIS, Dimitri; LUNARDI, Sara. Ativismo e autocontenção judicial no controle de constitucionalidade. In FELLET, André Luiz Fernandes; NOVELINO, Marcelo; PAULA, Daniel Giotti de. As nova faces do ativismo judicial.Bahia: Jus Podivm, 2013. p. 469. 
A proposta positivista em sua vertente renovada admite uma maior margem de atuação do intérprete da lei, para além da mera atividade de subsunção da lei ao caso concreto, contudo, tem como ideia central a premissa de que "o texto normativo objeto de exegese contém algo de objetivo, que não pode ser desconsiderado.,"229

Ainda que objeto das mais diversas críticas, tal qual ocorre à própria democracia, o positivismo jurídico em seu núcleo essencial, em seu caráter heterolimitador da atividade do intérprete aplicador do Direito mostra-se ainda como uma proposta à contenção dentro de balizas mínimas, prévias expressas pelo texto normativo, à atividade interpretativa.

Neste intento, busca-se equilibrar os excessos de subjetivismos e a falta de critérios claros de interpretação já esboçados no desenvolvimento deste trabalho, com a manutenção de um núcleo essencial legado pelo positivismo jurídico, ainda que renovado e influenciado pelas modernas teorias da interpretação.

A opção por uma abordagem positivista tende a afastar o intérprete/aplicador do Direito de preferencias pessoais, ou mesmo de escolhas morais ou valorativas para além deste conteúdo mínimo a ser respeitado, contido no texto normativo. ${ }^{230}$

Esta concepção coloca-se como um limite válido para que as decisões judiciais tomadas com base nestes textos abertos e de baixa precisão semântica da Constituição não solapem o resultado do próprio processo democrático.

Ainda que se entenda a democracia para além do critério puramente majoritário, o que se tem em mente na abordagem da questão não é uma crítica às Cortes Constitucionais ou a função judicial exercida no âmbito do controle de constitucionalidade em si própria, não se questiona aqui sua legitimidade por diversas razões, mas sim os excessos que a atuação do poder judiciário nestes campos movediços dos novos paradigmas de uma normatividade aberta da Constituição podem causar.

\footnotetext{
${ }^{229}$ RAMOS, Elival da Silva. Ativismo Judicial: parâmetros dogmáticos. São Paulo: Saraiva, 2010.

${ }^{230}$ DIMITRI, Dimoulis. A relevância prática do positivismo jurídico. In: Revista Brasileira de Estudos Políticos. Belo Horizonte, n. 102, p. 102, jan/jun 2011.
} 
Cremos na Jurisdição Constitucional como mecanismo essencial dentro de uma Democracia Constitucional, instrumento de preservação dos direitos fundamentais, no seu papel de controle frente aos abusos praticados pelos demais poderes, e pelo próprio Judiciário, na preservação do núcleo essencial de direitos consagrados em nossa Constituição $^{231}$; a crítica faz-se não em face da instituição, Tribunal Constitucional, mas sim, aos riscos trazidos pelo novo cenário traçado no decorrer desta Dissertação.

Lenio Luiz Streck, mesmo possuindo uma obra na qual se coloca em uma postura de valorização do conteúdo substancial da Constituição, mostra-se crítico às posturas pragmatistas em matéria de jurisdição:

\footnotetext{
A defesa de posturas substancialistas e concretistas acerca da utilização da jurisdição constitucional - que implica ineroxável avanço em relação às tradicionais posturas de self restraint - não pode ser confundida com decisionismos e atitudes pragmatistas, em que o Judiciário se substitui ao legislador, com o aumento desmesurado de protagonismos judiciais ${ }^{232}$.
}

Outro importante ponto de aperfeiçoamento do sistema, na busca do almejado equilíbrio, reside em um possível desenvolvimento deliberativo das Cortes Constitucionais.

Conrado Hübner Mendes mostra preocupação com o desenvolvimento no campo deliberativo das Cortes Constitucionais como meio de aperfeiçoamento de sua legitimidade, partindo da constatação de que "Cortes constitucionais são instituições consolidadas pela história recente da maioria das democracias, e críticas acadêmicas e teóricas dificilmente as farão desaparecer ${ }^{233}$.

Dentre as preocupações do autor, é importante destacar o foco na qualidade da deliberação, e não na busca de uma resposta correta como fazem as demais teorias da argumentação utilizadas neste campo.

\footnotetext{
${ }^{231}$ Para uma abordagem sobre o tema, TAVARES, André Ramos. Tribunal e Jurisdição Constitucional. São Paulo: Celso Bastos Editor, 1998.

${ }^{232}$ STRECK, Lenio Luiz. Verdade e Consenso: constituição, hermenêutica e teorias discursivas. $4^{\mathrm{a}}$. ed. São Paulo: Saraiva, 2011. p. 46.

${ }^{233}$ MENDES, Conrado Hübner. Desempenho deliberativo de cortes constitucionais e o STF. In MACEDO JÚNIOR, Ronaldo Porto; BARBIERI, Catarina Helena Cortada (Org). Direito e interpretação: racionalidades e instituições.. São Paulo: Saraiva, 2011. p. 346.
} 
Neste sentido, visando a qualidade do processo deliberativo no âmbito das cortes constitucionais, o professor da Faculdade de Direito do largo de São Francisco aponta a necessidade de critérios de correção, de forma a tornar mais claro e legítimo o processo argumentativo travado nas Cortes Constitucionais.

O autor traz quatro ônus a serem cumpridos no campo da argumentação deste processo deliberativo dos Tribunais, sendo eles: "transparência e sinceridade argumentativas", pela qual exige-se "explicitação das escolhas morais necessariamente envolvidas na interpretação constitucional, uma "consciência teórica ativada"; "densidade e consistência jurisprudencial", de forma a criar um cenário de coerência e continuidade, ou nas palavras do autor "conectar passado, presente e futuro, para desenvolver uma racionalidade incremental e, caso a caso, ao mesmo tempo prospectiva e retrospectiva"; "abertura para a deliberação interinstitucional”, ônus que parece conectar-se a uma espécie de contenção à atividade judicial por meio de diálogo interinstitucional, ou, implicando a "rejeição de uma atitude imperial oriunda de certo senso comum sobre a supremacia judicial, que não considera os atos legislativos como interpretações constitucionais genuínas"; "atitude crítica e construtiva perante a comunidade global de cortes", na busca de um diálogo com modelos do direito comparado ${ }^{234}$.

Em um segundo ponto de sua análise, ao lado de critérios para o implemento da qualidade argumentativa do processo decisório faz-se necessária uma observação sobre a capacidade deliberativa das Cortes Constitucionais, em nosso caso, do Supremo Tribunal Federal.

Com base no julgamento da ADI 3.150, a qual tratou do tema das células tronco embrionárias, o autor vê um Supremo Tribunal Federal dotado de "mecanismos eficientes e flexíveis para a preparação da deliberação, ou seja, para o momento 1 do esquema acima (especialmente pelos instrumentos da audiência pública e do amicus curiae).”, atendendose ainda ao fato do alto grau de publicidade que os atos praticados durante o julgamento receberam $^{235}$.

\footnotetext{
${ }^{234}$ MENDES, Conrado Hübner. Desempenho deliberativo de cortes constitucionais e o STF. In MACEDO JÚNIOR, Ronaldo Porto; BARBIERI, Catarina Helena Cortada (Org). Direito e interpretação: racionalidades e instituições.. São Paulo: Saraiva, 2011. p. 349-351.

${ }^{235}$ Idem, ibidem. p. 355-6.
} 
Aqui pedimos vênia ao respeitável entendimento do professor Hübner Mendes, em especial no que atine à observação da qualidade deliberativa do Supremo Tribunal Federal por meio da utilização do amicus curiae e das chamadas audiência públicas.

É inegável a abertura trazida pela previsão da figura do amicus curiae, da possibilidade de realização de audiências públicas, ou mesmo pela maior difusão do rol de legitimados ativos para propositura das chamadas ações diretas.

Contudo, há uma grande distância entre este crescimento da participação da sociedade no processo deliberativo dos Tribunais se comparada à, ainda que desgastada, amplitude de participação popular no processo político democrático por meio da democracia representativa ou partidária.

Este alargamento da participação na jurisdição constitucional, ainda que visto como uma importante melhoria e aproximação entre o Supremo Tribunal Federal e a população, não parece resolver as críticas apontadas à saciedade, no sentido de que, o processo deliberativo essencial a questões fundamentais tem sido retirado da ampla discussão popular, ainda que saibamos que entre o ideal democrático e a prática existe também um grande hiato, para o foro restrito do processo judicial.

Soma-se a isto as dificuldades subjacentes a um tema que tem sido enfrentado há tempos no debate jurídico e acadêmico, o déficit no acesso à justiça. A assunção das Cortes como espaço deliberativo, deve superar óbices históricos de acesso ao Poder Judiciário, e aqui remetemos à própria natureza da evolução de nosso sistema de controle de constitucionalidade que dia a dia tem restringido seu caráter de difusão, pelas mais diversas razões sociológicas ou técnico-jurídicas, sob pena dos esforços na criação de um ponto de equilíbrio entre nossa jurisdição constitucional e a democracia ficarem relegados ao plano de uma retórica falaciosa ${ }^{236}$.

\footnotetext{
${ }^{236}$ Dentro da proposta científica e dialógica desta Dissertação, cabe trazer argumento em sentido diverso, apresentado na obra Curso de Processo Constitucional: controle de constitucionalidade e remédios constitucionais, da autoria de Dimitri Dimoulis e Soraya Lunardi. Ao apontar as razões para a expansão do controle de constitucionalidade, os autores sustentam uma "crise de credibilidade do Legislativo", e de outro lado, e aqui pedimos vênia para a transcrição literal da referida obra, "a crescente facilidade de acesso dos cidadãos ao Poder Judiciário. O eleitor enfrenta intransponíveis barreiras se tentar convencer os legisladores a modificar ou revogar um dispositivo que considera prejudicial aos seus interesses. $\mathrm{O}$ mesmo eleitor, na qualidade de jurisdicionado, pode, com pouca despesa, com relativa celeridade e com reais chances de ganho de causa, pedir, no Brasil e em muitos outros países, a declaração de inconstitucionalidade de atos
} 
Ainda que teçamos as necessárias críticas, percebe-se na proposta de melhoria do processo deliberativo no âmbito da jurisdição constitucional a necessidade da construção de um modelo argumentativo que torne as referidas decisões mais legítimas e consistentes, à luz de uma fundamentação mais exaustiva e coerente com o sistema jurídico, a tradição jurisprudencial e o diálogo interinstitucional, sobretudo com o poder legislativo, adotando os Tribunais uma postura, quando necessária, passiva e de aceitação do processo de interpretação e construção realizado pelo poder deliberativo por excelência.

Na mesma linha dos trabalhos realizados por Conrado Hübner Mendes, o entendimento de Dimitri Dimoulis caminha no sentido da preocupação com a qualidade argumentativa destes processos decisórios, de forma a dotá-los de maior legitimidade.

O processo de aperfeiçoamento da argumentação exige do juiz a fundamentação das decisões "mediante argumentação jurídica específica e exaustiva, evitando as referências morais, de cunho subjetivo, e as remissões a princípios que, por serem genéricos e colidentes com outros princípios, raramente oferecem uma base sólida para decisão"237.

Dimoulis apresenta interessantes critérios de correção do exercício argumentativo contido no processo decisório judicial, de forma a dar-lhe limites consistentes e coerentes à uma interpretação sistêmica do Direito, reflexiva aos limites do próprio ordenamento jurídico.

São adotados cinco critérios, o da competência, no qual se investiga a competência do Poder Judiciário para a realização do controle; a utilização das fontes, pelo qual verifica-se a coerência e ponderação na escolha dos fundamentos da tese adotada, evitando manobras argumentativas; interpretação sistemática, pelo qual observa-se se há uma abordagem sistemática do direito vigente; a qualidade da subsunção, no qual se afere se "a consequência jurídica foi deduzida com rigor lógico de certa premissa ou trata-se de falsa subsunção; a qualidade de provas, onde é aferida se "as afirmações da decisão que

normativos que considera lesivos aos seus interesses. O Poder Judiciário é atualmente o mais acessível às demandas populares, individuais ou coletivas." (DIMOULIS, Dimitri; LUNARDI, Sara. Curso de processo constitucional: controle de constitucionalidade e remédios constitucionais. São Paulo: Atlas, 2011, p. 313).

${ }^{237}$ DIMITRI, Dimoulis; LUNARDI, Sara, Curso de processo constitucional: controle de constitucionalidade e remédios constitucionais. São Paulo: Atlas, 2011. p. 335. 
invocam fatos ou tendências foram comprovadas de maneira satisfatória ou permanecem retóricas" 238 .

Daniel Sarmento, em artigo denominado Ubiquidade constitucional: os dois lados da moeda, busca uma forma de equilíbrio entre estes pontos de tensão com base em três ítens, o primeiro deles o "emprego de uma metodologia racional, intersubjetivamente controlável e transparente"; o segundo, "a democratização do próprio exercício da jurisdição constitucional", em especial pelo incremento e melhoria de mecanismos como o amicus curiae e a realização das audiências públicas; e por derradeiro, "a adoção, pelos juízes, de uma postura de moderação e de respeito diante das decisões adotadas pelos demais poderes, em razão de seu lastro democrático-eleitoral"239.

No texto de Daniel Sarmento percebemos da mesma forma que as formulações de Conrado Hübner Mendes e Dimitri Dimoulis a busca da melhoria do processo deliberativo no âmbito das Cortes e uma maior higidez do ponto de vista da atividade interpretativa, de forma a tornar os argumentos contidos nas decisões coerentes de acordo com o Direito vigente, mantendo o já apontado na perspectiva positivista, sobre a existência de limites interpretativos à atividade do intérprete/aplicador do Direito.

As propostas do exercício de uma certa autocontenção pelos membros das Cortes Constitucionais, a observância de ônus argumentativos no âmbito da deliberação existente na formação da fundamentação das decisões judiciais, com a observância de critérios claros, reflexivos a um núcleo essencial do direito positivo, para que não transbordem em subjetivismos e pragmatismos de ocasião, e o incremento dos próprios meios de participação, a melhoria do processo deliberativo no âmbito destas Cortes, são etapas a serem observadas para que, ainda que não se elimine por completo a tensão a existente entre esta nova atuação judicial e a democracia, sejam mitigados seus efeitos.

Ainda que sobre a Democracia haja uma enorme diversidade de significados, tipologias e recortes existentes sobre o tema, tendentes a mudar-lhe os tons e os parâmetros, ainda que sobre ela pairem incertezas, o descrédito da nossa tão arranhada democracia representativa

${ }^{238}$ DIMITRI, Dimoulis. A relevância prática do positivismo jurídico. In: Revista Brasileira de Estudos Políticos. Belo Horizonte, n. 102, p. 228-9, jan/jun 2011.

${ }^{239}$ SARMENTO, Daniel. Ubiquidade constitucional: os dois lados da moeda. In: SARMENTO, Daniel. Livres e iguais: estudos de direito constitucional. Rio de Janeiro: Lumen Juris, 2006. p. 194. 
e dos partidos políticos ${ }^{240}$, a preservação de seu núcleo essencial certamente é fundamental à manutenção dos pilares de sustentação do próprio Estado de Direito.

Mais uma vez a lição de Manoel Goncalves Ferreira Filho, formador de gerações de constitucionalistas ao longo do exercício de sua cátedra na Faculdade de Direito do largo de São Francisco, nos alenta para aquilo que todas as críticas, crises e mudanças históricas sobre a Democracia parecem não ter alterado, "não há democracia, portanto, se o povo não se governa a si próprio" 241 .

As críticas e propostas trazidas buscam preservar esta essencialidade da democracia.

Não desejamos um apego a antigos standards teóricos e doutrinários firmados no nascimento do Constitucionalismo e do Estado moderno, mas sim conciliar, por meio dos ajustes necessários, estas novas realidades, em especial o avanço de nosso sistema de controle de constitucionalidade, o paradigma de uma normatividade ampla e aberta das atuais Constituições, das quais nossa Carta de 1988 figura como exemplo claro, a preservação de um caráter mínimo e certeza, previsibilidade e operacionalidade dogmática clara do sistema normativo, por consequência, à manutenção do princípio democrático, a centralidade do povo como detentor do poder soberano e da capacidade de autodeterminação dos seus próprios rumos na história ainda por escrever ${ }^{242}$.

\footnotetext{
${ }^{240}$ CAGGIANO, Monica Herman. Democracia x Constitucionalismo: um navio à deriva? In: Cadernos de Pós-Graduação em Direito, Comissão de Pós-Graduação da Faculdade de Direito da USP, São Paulo, n. 1, 2011.

${ }^{241}$ FERREIRA FILHO, Manoel Gonçalves. Princípios Fundamentais do Direito Constitucional. 2. ed. São Paulo: Saraiva, 2010.p. 44.

${ }^{242}$ Faz-se bem vinda a observação, como se costume, alvissareira do professor Tércio Sampaio Ferraz, nos alentando sobre as necessidade de pensarmos tais questões para o nosso tempo, na prática construtiva a partir destas realidades. "Sabemos ser impossível fazer voltar a roda do tempo. Em um livro publicado em 1982, de título bastante sugestivo - Despindo-se de Montesquieu (Abschied von Montesquieu) - Hans Girardi assinala que o princípio da divisão dos poderes não tem hoje a mesma relevância de outras épocas. Embora persistam as questões tradicionais referentes às funções de controle na relação entre os poderes, o eixo da discussão torna-se agora a dicotomia tipicamente tecnológica macropoder/micropoder. Os riscos de uma desneutralização política do Judiciário não serão evitados pela volta ao passado, mas por serem encarados, no contexto social de nossos dias, como desafios. Não se trata, pois, de preservar antigos equilíbrios, mas de evitar a manipulação do homem pela tecnologia e por todas as formas de poder que ela alimenta. Não certamente pelo desejo - utópico - de eliminá-la, mas valendo-se, talvez, da sua própria reflexibilidade, descobrindo na sua prática o seu limite e sua extensão. A questão é, afinal, como construir, com esse objetivo, uma tecnologia jurídica.” (FERRAZ JR., Tércio Sampaio. Direito Constitucional: liberdade de fumar, privacidade, estado, direitos humanos e outros temas. Barueri: Manole, 2007. p. 409).
} 


\section{Conclusão}

No decorrer dos capítulos anteriores, buscou-se em um primeiro momento construir uma necessária análise evolutiva, tendo como ponto de partida a era das revoluções setecentistas, o advento do Constitucionalismo Moderno e seus postulados centrais, nos quais fincamos as balizas do princípio da separação de poderes, tal como concebido pelos pais da doutrina. e os contornos essenciais de cada uma das funções, traçando as principais alterações sentidas nesta concepção que aqui chamamos de clássica pela influência de alguns fatores como o período pós-segunda guerra mundial e o Estado-Providência, com seus direitos fundamentais de segunda geração e suas demandas prestacionais.

Concluímos que não obstante as modificações sentidas no princípio da separação de poderes, com as importantes incursões de Nuno Piçarra e Karl Loewenstein, em que o conceito da separação de poderes passa a ser instrumental e subordinado a uma democratização do poder, e não como um fim em si mesmo, reforçando-se a importância do princípio como estruturante de mecanismos de controle entre as funções, ressaltada a importância do Poder Judiciário como órgão fiscalizador e de controle sobre os órgãos de natureza política, governo e parlamento, de forma a dar suporte às decisões tomadas na sociedade sob a égide do processo democrático, havendo um núcleo essencial de competência a ser preservado em relação a cada Poder instituído.

Em um segundo momento, demonstramos um panorama, por meio da colação e a análise de autores clássicos do Direito Constitucional brasileiro, como Pedro Lessa, João Mendes de Almeida Junior, Herculano de Freitas, Sampaio Doria sobre o Poder Judiciário a partir do final do século XIX, início do século XX, nos quais o conceito e os limites da jurisdição mostravam-se muito próximos aos contornos traçados no advento das revoluções liberais.

Um Poder Judiciário que se afastava das funções de intérprete da Constituição in abstrato, que se constituía em um foro primordialmente de resolução de casos concretos, adstrito a balizas textuais de uma normatividade mais restrita sob o ponto de vista semântico se comparada aos parâmetros normativos atuais. 
Feito este necessário trajeto evolutivo, buscou-se por meio de uma análise dialética entre posições doutrinárias divergentes a construção de um trabalho de pesquisa cuja contribuição essencial reside na constatação de pontos fundamentais que traçam os contornos do atual quadro existente na atividade judicial, em especial sob o enfoque da atividade exercida pelas Cortes responsáveis pela última palavra no âmbito do controle judicial de constitucionalidade.

É com base nestes pontos fundamentais, que podemos alçar algumas conclusões sobre a questão central enfrentada nesta Dissertação, visando, ainda que de forma singela, contribuir ao debate acadêmico deste tema em franco desenvolvimento na nossa realidade político-constitucional.

Dentro do recorte adotado, concluímos que o avanço do Poder Judiciário às fronteiras do chamado ativismo judicial, e aqui adotamos a terminologia tanto sob seu viés pejorativo, como sob aquele que enxerga nesta postura uma ferramenta necessária e desejada ao implemento das promessas constitucionais herdadas de nossa Constituinte, tem seu surgimento facilitado pela conjugação de dois elementos, de um lado o desenvolvimento amplo do sistema judicial de controle de constitucionalidade, e de outro, as características de nossa normatividade constitucional.

O desenvolvimento de nosso sistema de controle de constitucionalidade resultou fundamentalmente após o advento da Constituição de 1988, das emendas constitucionais n. 3/1993 e 45/2004 e das Leis 9.868/99 e 9.882/99, em um modelo de preponderância judicial-repressiva, cujo controle abstrato das normas passa a ser figura central, chegandose a falar em uma tendência da abstrativização do sistema, sobretudo por força do desenvolvimento das chamadas ações diretas.

A referida sofisticação dos mecanismos judiciais de controle de constitucionalidade ocorre essencialmente pela verificação do seguintes fatores: a franca ampliação do rol de legitimados para propositura das ações diretas, anteriormente reservada ao Procurador Geral da República; o surgimento da Arguição de Descumprimento de Preceito Fundamental, ADPF, prevista no art. 102, $\S 1^{\circ}$ da CF, regulamentada pela Lei 9.882/99 e da Ação Declaratória de Constitucionalidade, inserida pela EC 3/1993; a possibilidade de modulação dos efeitos temporais das decisões proferidas em sede de controle concentrado 
de constitucionalidade trazida pelo art. 27 da Lei 8.68/99; a criação pela EC 45/2004 das chamadas súmulas vinculantes, com a atribuição de efeitos típicos das decisões proferidas em sede de controle abstrato às súmulas extraídas do manejo de decisões proferidas em sede de controle difuso; a evolução do Mandado de Injunção; o advento do amicus curiae e a possibilidade de convocação de audiências públicas em sede das ações diretas, ampliando o raio de participação social nas questões enfrentadas no âmbito destas ações; a natureza dos efeitos das decisões proferidas em sede de controle abstrato, com alcance erga omnes e efeito vinculante; os avanços nas técnicas decisórias e dos métodos interpretativos utilizados nas decisões de controle, como por exemplo as decisões aditivas e os métodos de interpretação conforme à Constituição.

Este fortalecimento dos mecanismos de controle de constitucionalidade, resultante no crescimento do viés abstrato e concentrado do nosso modelo, embora preservada ainda a possibilidade do exercício do controle por via difusa e incidental, a assunção de um caráter preponderantemente judicial-repressivo do controle de constitucionalidade, forneceram os meios necessários para que o Supremo Tribunal Federal pudesse assumir posição de destaque não somente no âmbito do controle de constitucionalidade, mas por consequência, no próprio cenário político-institucional.

Ao lado dos fatores acima descritos, a característica analítica da Constituição de 1988, cujo texto conjuga as mais diversas pautas representativas de múltiplos interesses, representativos de valores plurais, no intuito de uma ampla democratização de Direitos, expressa nos parâmetros lassos de uma normatividade carregada de princípios e cláusulas de conteúdo semântico aberto, preceitos de textura ampla e de baixa densidade conceitual, acarretou um alargamento interpretativo nunca antes visto, gerando dificuldades no refinamento dos limites interpretativos de nosso bloco de constitucionalidade.

A conjugação destes dois fatores, de um lado o ferramental amplo de nosso sistema de controle de constitucionalidade outorgado ao Supremo Tribunal Federal, e, a matériaprima extremamente maleável e imprecisa de nosso texto constitucional, permitiu o avanço do Poder Judiciário a espaços pertencentes ao âmbito do processo político-democrático.

Somam-se a este quadro as influências da corrente neoconstitucionalista ou de revalorização de um moralismo jurídico, que conclama esta parcela do Poder a concretizar 
direitos consagrados na Constituição dentro de um quadro em que se rompem os limites de separação entre a moral e o direito, e o médium tradutor desta normatividade, para além dos parâmetros da dogmática positivista, passa a ser o Poder Judiciário.

Os parâmetros hermenêuticos de interpretação constitucional propostos pelas chamadas correntes moralistas do Direito ou neoconstitucionalistas, em sua visão mais radical, eclodem os limites interpretativos possíveis do texto normativo ao buscar a fundamentação de suas decisões no campo da moral e da filosofia de valores, de certa forma subjacente ao próprio texto constitucional, devido às características já mencionadas de sua normatividade, típica das sociedades pluralistas e do Estado Constitucional.

A soma destes fatores, aliada ainda à crise dos sistemas democráticos representativos, tem colocado o poder judiciário, e esta realidade sente-se quando observada a atuação do Supremo Tribunal Federal, em uma posição de protagonismo sobre questões fundamentais, configurando-o como novo agente deliberativo sobre estes temas, em substituição ao próprio processo político-democrático.

Dentro deste cenário, constata-se invariavelmente que o Poder Judiciário tornou-se o foro deliberativo das mais amplas questões centrais do debate social: as características de nosso modelo de controle aliadas a esta normatividade aberta ocasionaram um processo de crescimento da função judicial, e de deslocamento do campo deliberativo sobre questões que ultrapassam a mera função de controle de conformidade dos atos dos demais poderes à legalidade constitucional.

O núcleo essencial da função judicial se expande para além de seus lindes clássicos, ultrapassando até mesmo as modernas funções de controle delineadas na doutrina constitucionalista, como observado nas análises da obra de Nuno Piçarra e Karl Loewenstein.

Os riscos de uma atividade judicial ativista, tomada sua definição como a atuação do poder judiciário para além dos limites do sistema normativo, com base em uma atividade de interpretação, construção e aplicação do Direito fundada em parâmetros normativos de uma textualidade vaga, de baixa densidade semântica e conceitual, cuja hermenêutica propõe o rompimento dos limites entre a Moral e o Direito, residem fundamentalmente no 
enfraquecimento do caráter deontológico do Direito, heterolimitador da norma, utilizando aqui a crítica de Jürgen Habermas, na medida em que o campo argumentativo e de fundamentação das decisões abre-se para fronteiras de difícil aferição.

Esta tensão se sente em postulados básicos do Estado de Direito, como a segurança jurídica, a previsibilidade, característica fundamental do sistema normativo, o princípio da separação de poderes, ainda que renovado e visto somente em relação ao núcleo básico de cada uma de suas funções.

Como maior consequência, atinge o próprio princípio democrático, quando o Poder Judiciário, sem que haja participação efetiva da população ou a reflexividade necessárias das decisões em parâmetros normativos claros, frutos estes do processo político democrático, acaba por exercer a atividade típica de embricamento entre o texto normativo e conceitos morais e axiológicos, como em uma espécie de nova nomogênese, contudo $a$ posteriori, avocando a função de construção e adensamento destes preceitos constitucionais de textura aberta, sem que haja o devido balanceamento ao valor da Democracia.

A adoção de decisões lastreadas nesta normatividade aberta, fluída, realizadas dentro de uma concepção juriscêntrica deste processo de tradução de valores e de uma moralidade subjacentes à Constituição, tende ao enfraquecimento do sistema normativo e das normas de caráter inferior, colocando o Poder Judiciário em uma constante atividade de construção da própria normatividade, sem que haja um diálogo amplo com a sociedade, dentro de uma concepção essencial de democracia.

Se estas são conclusões que partem da crítica sobre o quadro atual da atividade judicial e seu cotejo com a democracia, cremos que devem servir de norte ao aprimoramento da questão, para que sejam corrigidos eventuais excessos e desvios existentes.

Como observado no desenvolvimento deste trabalho, as características desta nova normatividade aberta de nosso texto constitucional e o fortalecimento de nosso sistema de controle judicial de constitucionalidade são dados que, sejamos favoráveis ou não, parecem corresponder a uma realidade histórica inexorável. 
Tomado o núcleo essencial do princípio democrático pela participação da população nos processos de decisão sobre as questões que a afetam de forma direta, detentora de todo o poder supremo, para além de qualquer arranjo institucional vigente, fazem-se necessários ajustes no exercício da atividade judicial para que não se esvazie ainda mais um já desacreditado processo democrático.

Como propostas de aprimoramento da atuação do poder judiciário visando um aumento no equilíbrio entre o chamado ativismo judicial e os postulados democráticos, podemos destacar: o desenvolvimento de um postura de autocontenção pelos membros das Cortes Superiores de forma a evitar excessos na intervenção judicial, afastando-se ao mesmo tempo de um indesejado passivismo judicial, respeitando os espaços de conformação legislativa e consequentemente de participação popular democrática no desenvolvimento de questões fundamentais à sociedade ao adotar uma postura de viés minimalista no manejo das ações de controle de constitucionalidade; a adoção de um positivismo renovado, utilizando a terminologia e orientação adotada na obra de Elival da Silva Ramos, pelo qual reconhece-se os avanços da moderna hermenêutica, preservando contudo, o núcleo essencial contido no texto normativo como limite à atividade do intérprete/aplicador do Direito; o incremento da qualidade argumentativa dos Tribunais, com a observância de ônus argumentativos claros e mais restritos no âmbito da deliberação existente na formação da fundamentação das decisões judiciais, por meio de critérios objetivos, reflexivos a um núcleo essencial do direito positivo, passando pelo necessário desenvolvimento pela doutrina e jurisprudência de critérios de aferição da correção e higidez do processo decisório/argumentativo;

Ressaltamos também, sem prejuízos das propostas fundamentais acima mencionados, a possibilidade de adoção de uma cultura de diálogo institucional entre os poderes judiciário, legislativo e executivo, de forma a favorecer um processo de legitimidade destas decisões, cuja tônica resida em uma concepção dinâmica sobre a separação de poderes, em que a qualidade das decisões seja colocada ao crivo de sua aceitabilidade pela opinião pública e submetida ao controle dos demais órgãos do Poder, para além de uma legitimidade meramente procedimental na definição do caráter democrático das referidas decisões. 
Ajustes são necessários para que, além da crítica, possamos compatibilizar estas novas características do Direito Constitucional, que em parte parecem ser resultado da própria evolução da sociedade e das formas de exercício do Poder, com um núcleo essencial de postulados necessários à preservação da própria democracia e aos ideais, ainda que renovados, do Constitucionalismo Moderno. 


\section{REFERÊNCIAS BIBLIOGRÁFICAS}

ACKERMAN, Bruce. Nós, o povo soberano: Fundamentos do Direito Constitucional. Mauro Raposo de Mello (Trad.). Belo Horizonte: Del Rey, 2006.

SILVA, Afonso da. Curso de Direito Constitucional Positivo. 21. ed. rev. e atual. São Paulo: Malheiros, 2002.

AGRA, Walber de Moura; BRITTO, Thays Oliveira de. Neoconstitucionalismo. In: FRANCISCO, José Carlos. (coord. e coautor). Neoconstitucionalismo e atividade jurisdicional: do passivismo ao ativismo judicial. Belo Horizonte: Del Rey, 2012.

ALMEIDA JÚNIOR, João Mendes de. Direito Judiciário Brasileiro. $5^{\mathrm{a}}$. ed. Rio de Janeiro: Livraria Freitas Bastos S/A, 1960.

AMARAL JÚNIOR, José Levi Mello do. Sobre a organização de poderes em Montesquieu: comentários ao capítulo VI do Livro XI de $\mathrm{O}$ espírito das leis. In: Revista dos Tribunais. v. 97, n. 868, p. 53-68, 2008.

ÁVILA, Humberto. "Neoconstitucionalismo": entre "Ciência do Direito" e o "Direito da Ciência". In: BINENBOJM, Gustavo; NETO, Cláudio Pereira de Souza; SARMENTO, Daniel (Coord.). Vinte Anos da Constituição Federal de 1988. Rio de Janeiro: Lumen Juris, 2009.

BALEEIRO, Aliomar. Supremo Tribunal Federal, esse outro desconhecido. Rio de Janeiro: Forense, 1968.

BARCELLOS, Ana Paula; BARROSO, Luis Roberto. O começo da história: a nova interpretação constitucional e o papel dos princípios no direito brasileiro. In: SILVA, Virgílio Afonso da (Org.). Interpretação constitucional. 1. ed. São Paulo: Malheiros Editores, 2005.

BARROSO, Luís Roberto. Neoconstitucionalismo e constitucionalização do direito (O triunfo tardio do direito constitucional no Brasil). In: Revista de Direito Constitucional e Internacional: Caderno de Direito Constitucional e Ciência Política, ano 15, n. 58, p. 1301, janeiro-março/2007.

BEÇAK, Rubens. A Separação de Poderes, o Tribunal Constitucional e a Judicialização da Política. In: Revista da Faculdade de Direito da Universidade de São Paulo FDUSP. (no prelo). Faculdade de Direito da Universidade de São Paulo FDUSP, v. 103, p. 325-336, 2008.

Controle Difuso (Aspectos Gerais). In: Comentários à Constituição Federal de 1988. Coordenadores científicos: Paulo Bonavides; Jorge Miranda; Walber de Moura Agra. Coordenadores editoriais: Francisco Bilac Pinto Filho, Octávio Luiz Rodrigues Júnior. Rio de Janeiro: Forense, 2009.

. A Hipertrofia do Executivo Brasileiro: o impacto da Constituição de 1.988. Campinas: Millennium Editora, 2008. 
BONAVIDES. Paulo. Curso de Direito Constitucional. 27. ed. atual. São Paulo: Malheiros Editores, 2012.

. Do Estado Liberal ao Estado Social. 9a . ed. São Paulo: Malheiros Editores, 2009.

BRANCO, Paulo Gustavo Gonet. Juízo de Ponderação na jurisdição constitucional. São Paulo: Saraiva, 2009.

BRANCO, Paulo Gustavo Gonet; MENDES, Gilmar Ferreira. Curso de Direito Constitucional. $7^{\mathrm{a}}$. ed. São Paulo: Saraiva, 2012.

BRASIL. Supremo Tribunal Federal. ADPF $n^{0}$ 101, Plenário do Supremo Tribunal Federal. Voto do Ministro Eros Grau. Brasília, DF, 24 de junho de 2009. Disponível em: $<$ http://www.stf.jus.br/arquivo/cms/noticiaNoticiaStf/anexo/ADPF101ER.pdf $>$. Acesso em 23/11/2013.

BRASIL. Supremo Tribunal Federal. ADI no 3510, Plenário do Supremo Tribunal Federal. Voto do Ministro Gilmar Mendes. Brasília, DF, 29 de maio de 2008. Disponível em: $<$ http://www.stf.jus.br/arquivo/cms/noticiaNoticiaStf/anexo/ADI3510GM.pdf $>$. Acesso em 22/11/13.

CAMBI, Eduardo. Neoconstitucionalismo e neoprocessualismo: direitos fundamentais, políticas públicas e protagonismo judiciário. São Paulo: Revista dos Tribunais, 2009.

CAGGIANO, Monica Herman. Democracia x Constitucionalismo: um navio à deriva? In: Cadernos de Pós-Graduação em Direito, Comissão de Pós-Graduação da Faculdade de Direito da USP, São Paulo, n. 1, 2011.

CANOTILHO, José Joaquim Gomes. Direito Constitucional e Teoria da Constituição. $7^{\mathrm{a}}$. ed. Lisboa: Almedina, 2003.

CHEVALLIER, Jacques. O Estado pós-moderno. Marçal Justen Filho (Trad.) Belo Horizonte: Fórum, 2009.

CLEVE, Clèmerson Merlin. Atividade Legislativa do Poder Executivo. 2a . ed. São Paulo: RT, 2000.

DAHL, Robert A. Sobre a democracia. Beatriz Sidou (Trad). Brasília: Editora Universidade de Brasília, 2009.

DIMITRI, Dimoulis. Além do ativismo e do minimalismo judicial no campo dos direitos fundamentais. Justificação jurídica de decisões e competências. In: FRANCISCO, José Carlos. Neoconstitucionalismo e atividade jurisdicional: do passivismo ao ativismo judicial. Belo Horizonte: Del Rey, 2012.

A relevância prática do positivismo jurídico. In: Revista Brasileira de Estudos Políticos. Belo Horizonte, n. 102, pp. 215 - 253, jan/jun 2011. 
DIMITRI, Dimoulis; LUNARDI, Sara. Ativismo e autocontenção judicial no controle de constitucionalidade. In FELLET, André Luiz Fernandes; NOVELINO, Marcelo; PAULA, Daniel Giotti de. As nova faces do ativismo judicial.Bahia: Jus Podivm, 2013.

- Curso de processo constitucional: controle de constitucionalidade e remédios constitucionais. São Paulo: Atlas, 2011.

DISCURSO proferido pelo Ministro Celso De Mello, em nome no Supremo Tribunal Federal, na solenidade de posse do Ministro Carlos Ayres Britto Na Presidência Da Suprema Corte Do Brasil, em 19/04/2012. Disponível em $<$ http://www.stf.jus.br/arquivo/cms/noticiaNoticiaStf/anexo/discursoCM.pdf $>$. Acesso em 20/11/2013.

DORIA, Antonio de Sampaio. Direito Constitucional. São Paulo: Max Limonad, 1958. p. 617.v. 1.

ELY, John Hart. Democracia e Desconfiança: uma teoria do controle judicial de constitucionalidade. Juliana Lemos (Trad). São Paulo: WMF Martins Fontes, 2010.

FERRAZ JR., Tércio Sampaio. Direito Constitucional: liberdade de fumar, privacidade, estado, direitos humanos e outros temas. Barueri: Manole, 2007.

FERREIRA FILHO, Manoel Gonçalves. A democracia no liminar do século XXI. São Paulo: Saraiva, 2001.

2011. . Aspectos do Direito Constitucional Contemporâneo. 3ª ed. São Paulo: Saraiva, Do processo legislativo. São Paulo: Saraiva, 2002.

O papel político do judiciário e suas implicações. In: FRANCISCO, José Carlos (Coord. e coautor). Neoconstitucionalismo e atividade jurisdicional: do passivismo ao ativismo judicial. Belo Horizonte: Del Rey, 2012.

2010.

Princípios Fundamentais do Direito Constitucional. 2a. ed. São Paulo: Saraiva,

FRANCISCO, José Carlos. (Neo) Constitucionalismo na Pós-Modernidade: Princípios Fundamentais e Justiça no Caso Concreto. In: FRANCISCO, José Carlos (Coord. e coautor). Neoconstitucionalismo e atividade jurisdicional: do passivismo ao ativismo judicial. Belo Horizonte: Del Rey, 2012.

FREITAS, Herculano de. Direito Constitucional. São Paulo: [s. e.], 1923.

GALVÃO, Jorge Octávio Lavocat. Concentração de Poder da Jurisdição Constitucional: Uma análise crítica de seus pressupostos filosóficos. In: ALMEIDA, Fernando Dias Menezes de; AMARAL JÚNIOR, José Levi Mello do; LEAL, Roger Stiefelmann; HORBACH, Carlos Bastide (Coord.). Direito Constitucional, Estado de Direito e Democracia: Homenagem ao Prof. Manoel Gonçalves Ferreira Filho. São Paulo: Quartier Latin, 2011. 
GALVÃO, Jorge Octávio Lavocat. O neoconstitucionalismo e o fim do Estado de Direito. Tese de doutorado. Faculdade de Direito da Universidade de São Paulo. São Paulo, 2012.

HABERMAS, Jürgen. Direito e Democracia: entre facticidade e validade. $2^{\mathrm{a}}$. ed. Flávio Beno Siebeneichler (Trad). Rio de Janeiro: Tempo Brasileiro, 2012. p. 297. V. 1.

HIRSCHL, Ran. Towards Juristocracy: The origins and consequences of the new constitucionalism. Massachussets: Harvard University Press, 2005.

HORBACH, Carlos Bastide. A nova roupa do Direito Constitucional, pós positivismo e outros modismos. In: Revista dos Tribunais, v. 859, ano 96, p. 81-91, maio de 2007.

KELSEN, Hans. Teoria Pura do Direito. João Baptista Machado. (Trad.). 8. ed. São Paulo: Editora WMF Martins Fontes, 2009.

LEAL, Roger Stiefelmann. O exercício da jurisdição constitucional pelo poder judiciário. In: ALMEIDA, Fernando Dias Menezes de; AMARAL JÚNIOR, José Levi Mello do; LEAL, Roger Stiefelmann; HORBACH, Carlos Bastide (Coord.). Direito Constitucional, Estado de Direito e Democracia: Homenagem ao Prof. Manoel Gonçalves Ferreira Filho. São Paulo: Quartier Latin, 2011.

LESSA, Pedro. Do Poder Judiciário. Rio de Janeiro: Livraria Francisco Alves, 1915.

LOCKE, John. Dois tratados sobre o governo. Julio Fischer (Trad). $2^{\text {a }}$. ed. São Paulo: Martins Fontes, 2005.

LOEWENSTEIN, Karl. Teoria de la Constitucion. Alfredo Gallego Anabitarte (Trad.). Barcelona: Ediciones Ariel, 1965.

MAUS, Ingeborg. Judiciário como superego da sociedade: o papel da atividade jurisdicional na "sociedade órfã". In: Novos Estudos CEBRAP, n. 58, p. 185, nov. 2000.

MENDES, Conrado Hubner. Direitos fundamentais, separação de poderes e deliberação. São Paulo: Saraiva, 2011.

. Desempenho deliberativo de cortes constitucionais e o STF. In: BARBIERI, Catarina Helena Cortada; MACEDO JÚNIOR, Ronaldo Porto (Org.). Direito $e$ interpretação: racionalidades e instituições. São Paulo: Saraiva, 2011.

. Controle de Constitucionalidade e Democracia. Rio de Janeiro: Elsevier, 2008.

MENDES, Conrado Hübner; SILVA, Virgílio Afonso da. Habermas e a Jurisdição Constitucional. In: NOBRE, Marcos; TERRA, Ricardo (Org.). Direito e Democracia: um guia de leitura de Habermas. São Paulo: Malheiros Editores, 2008.

MENDES, Gilmar Ferreira. Direitos fundamentais e controle de constitucionalidade: estudos de Direito Constitucional. 3. ed. rev. e ampl. São Paulo: Editora Saraiva, 2004.

Jurisdição Constitucional: o controle abstrato de normas no Brasil e na Alemanha. 5. ed. São Paulo: Editora Saraiva, 2005. 
MIRANDA, Jorge. Manual de Direito Constitucional. Tomo II. Constituição. 5a . ed. Coimbra: Coimbra Editora, 2005.

MIRANDA, Jorge. Manual de Direito Constitucional. Tomo III. Estrutura Constitucional do Estado. 5a . ed. Coimbra: Coimbra Editora, 2004.

MONTESQUIEU, Charles Louis de Secondat, baron de la Brède et de. O Espírito das leis. Edson Bini (Trad.). São Paulo: Edipro, 2004.

MORAES, Alexandre de. Direito Constitucional. 28ª ed. São Paulo: Atlas, 2012.

PIÇARRA, Nuno. A Separação dos Poderes como Doutrina e Princípio Constitucional. Coimbra: Coimbra Editora, 1989.

RAMOS, Elival da Silva. Ativismo Judicial: parâmetros dogmáticos. São Paulo: Saraiva, 2010. Saraiva, 2010.

Controle de constitucionalidade no Brasil: perspectivas de evolução. São Paulo:

RAWLS, John. O liberalismo politico. ed. ampl. Álvaro de Vita (Trad.). São Paulo: WMF Martins Fontes, 2011.

REALE, Miguel. Filosofia do Direito. 20ª ed. São Paulo: Saraiva, 2002.

ROCHA, Jean Paul C. Veiga da. Separação dos Poderes e Democracia Deliberativa. In: NOBRE, Marcos; TERRA, Ricardo (Org.). Direito e Democracia: um guia de leitura de Habermas. São Paulo: Malheiros Editores, 2008.

SALDANHA, Nelson. O Estado moderno e a separação de poderes. São Paulo: Saraiva, 1987.

SARMENTO, Daniel. Interpretação Constitucional, Pré-compreensão e Capacidades Institucionais do Intérprete. In BINENBOJM, Gustavo (coord); SOUZA NETO, Cláudio Pereira de; SARMENTO, Daniel. Vinte Anos da Constituição Federal de 1988. Rio de Janeiro: Lumen Juris, 2009.

- Ubiquidade constitucional: os dois lados da moeda. In: SARMENTO, Daniel. Livres e iguais: estudos de direito constitucional. Rio de Janeiro: Editora Lumen Juris, 2006.

SCHMITT, Carl. La Tirania de los Valores. Anima Schmitt de Otero (Trad.). In: Revista de Estudios Políticos, Madrid, 115, p. 68, Enero-Frebrero/1961.

STRECK, Lenio Luiz. Verdade e Consenso: constituição, hermenêutica e teorias discursivas. 4a . ed. São Paulo: Saraiva, 2011.

SUNDFELD, Carlos Ari Vieira; MACEDO JÚNIOR, Ronaldo Porto (org); BARBIERI, Catarina Helena Cortada (org). Princípio é preguiça? In: Direito e interpretação: racionalidades e instituições. São Paulo: Saraiva, 2011. 
TATE, C. Neal. Why the expansion of judicial power? In: TATE, C. Neal; VALLINDER, Torbjörn. The Global Expansion of Judicial Power. New York: New York University Press, 1995.

TAVARES, André Ramos. Curso de Direito Constitucional. $9^{\text {a }}$. ed. rev. e atual. São Paulo: Editora Saraiva, 2011. . Tribunal e Jurisdição Constitucional. São Paulo: Celso Bastos Editor, 1998.

VALLINDER, Torbjörn. When the courts go marching in. In: TATE, C. Neal; VALLINDER, Torbjörn. The Global Expansion of Judicial Power. New York: New York University Press, 1995.

VIEIRA, Oscar Vilhena. A moralidade da Constituição e os Limites da Empreitada Interpretativa, ou entre Beethoven e Bernstein. In: SILVA, Virgilio Afonso da (org). Interpretação Constitucional. São Paulo: Malheiros Editores, 2007. 1808-2432.

Supremocracia. In: Rev. direito $G V$ [online]. vol.4, n.2, pp. 441-463. 2008. ISSN

VILE, Maurice J. C. Constitutionalism and the separation of powers. 2a . ed. Indianapolis: Liberty Fund., 1998.

ZAGREBELSKY, Gustavo. Estado Constitucional. In: HORBACH, Carlos Bastide et al (coord.). Direito Constitucional, Estado de Direito e Democracia: Homenagem ao Prof. Manoel Gonçalves Ferreira Filho. São Paulo: Quartier Latin, 2011. 